\title{
一 般 演 題(後半)
}

（20）直腸，結腸に発生したポリープの外科的 処置について

\author{
東邦大学第一外科 \\ 片山圭男, 柳田 謙藏, 宮下䈏士弥
}

昭和38年 1 月上り昭和 44 年 7 月迄に当院第一外科で入 院加療を加之た3244名中，谊腸，結腸ポリープは28例 $(0.9 \%)$ であり, adenomatous polyp 25例, villous adenoma 3 例で，その中 6 例に malignant change が 五り, villous 存ものは全例 malignant ゙゙すまし t.

男性22，女性6 023.3\%で， Bacon の女性 $29.8 \%$ に 比心幾分少ない様に思われます，年齢は40歳以上 14 例, 40歳以下14例と同数で40藏以上に多いという事はありま せん。

主訴は血便および肚門出血が圧倒的に多く24例でその 他江肛門部異和感ポリープ脱出, 便秘, 腹痛等でありま す. 病腷期間は 1 週から10年と椂々でありますが，一年 以上の者が米数以上を占めています，「痔核だるう」とい う事で放置していた者が多かった様です。

われわれの症例28例中，面腸20例，S状結晹が8例で その他の結腸には1例もなかった. Helwig が autopsy で直腸およびS状結腸にポリープがはったもの，43.7 $\%$ Griunell が clinical には同部に $80 \%$ 以上も占め ていたと報告していますが，この事はS 状結腸以上のポ リープの発見が非常に困難である事を意味するのであり ましょう。

malignant な症例は大きさ0 5 $\mathrm{mm} の 2$ 例中 1 例 5 $10 \mathrm{~mm}$ の14例中 1 例, $10 \mathrm{~mm}$ 以上の 12 例中 4 例であり ました. carcinoma への移行を考える時, その polyp の大きさは重要な意味をもつものであります. Grinnell and Laue, Culp, Ortmayer 等はポリープの大きさが $1 \mathrm{~cm}$ 以上のむのは，その悪性率及悪性度が高いと報告 していますが，われわれの症例です $1 \mathrm{~cm}$ 以下の 2 例を 除き明らかに，乙の事を示している様に思われます。

$5 \mathrm{~mm}$ 以下の1例は肛門翰より $10 \mathrm{~cm} の$ villous adenoma $と 15 \mathrm{~cm} の$ 所に satellite polyp 数個持った ものであり, Culp の satellite polyp をもつもの恶性 率は36\%であったとの報告からもうなつけます，6〜10 $\mathrm{mm}$ の一例は villous adenoma で Biopsyにより focal carcinoma t証明したものであります. $21 \mathrm{~mm}$ 以上の
4 例㹥全く adenomatous invasive でありましたので， 前 2 例に比へ，覀性度が高いものでありました。

スライドは 5 年前より血便を来たした 28 歳の男性で大 きさ $3 \times 3.5 \mathrm{~cm}$, 茥約 $2 \mathrm{~cm}$ の直腸ポリープで肛門輪より $6 \mathrm{~cm}$ 後壁に位置していたもので経肚門的に周囲粘膜を 含め polypectomyを行ないました.

スライドは同しく 1 等前からの伹便を主訴とした25歳 女性で，大きさ $2.5 \times 3 \mathrm{~cm}$ ，茥約 $1.5 \mathrm{~cm}$ で，肛門鐱よ り $18 \mathrm{~cm}$ のポリープで, 経腹的に手術定行ない, 周国の 浸潤のないものを碓かわ, partial sigmoidectomy 約 6 $\mathrm{cm}$ を行ないました。この症例 2 例共, 病理学的には adenomatous polyp でありました.

次のレントゲンスライドの症例は㨁腸膨大部の鷄卵大 の巾広い adenomatous な増殖性を有する腺上皮が異型 性重層性の濃染核をもつ precancer でありましたので， anterior resectionを行ないました. 術後の病理検查 では，高度の異型性を持つ円杜上皮が腺棈造を作る adenomatous invasive でありました。

当教室に於いて行った手術方法は単なる polypectomy 13例, anorectal line 付近に存在するポリープは結然 切除を行ない7例，他のものは腸切除を施行したもので す、hemicolectomy を行なった症例は肍門輪より $7 \mathrm{~cm}$ の所の直径 $1 \mathrm{~cm}$ の有経性ポリープで biopsy の結果 adenomatous polyp でありましたが, 注腸透視で横行結 腸に polyposisの疑わしい所見がありましたので，開腹 を行なった所, coloscope にて, 小豆大の数ヶの polyp を発見 malignant changeを恐れて行なったものであり ます. total colectomy の症例は, satellite polyp を持 ったS状結腸の villous adenoma で開腹時上行結腸に も横行結腸にも同様の polyp を証明しむしたので行なっ たものであります. Pull-through, Miles'の症例㳉共に anorectal junction 近くに在り, 病理学的検索にて, adenocarcinoma invasive で周囲への浸潤が考えられ ましたので radical ope. に踏み切ったものであります。

以上 malignant potential を考える時, 諸家の報告に あります様に, adenomatous polyp は6\%内外, villous adenoma は12 31.9\%, satellite polyp では36\% という多きを数えむす。たとえその polyp 加良性で市 るとしても，大きさが $1 \mathrm{~cm}$ 以上のもの，villous なも

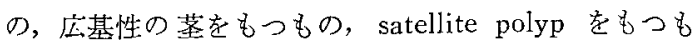
の，家族性の強いもの，等は一応要性への移行を考方る 
必要がある様に思われますので，病理学的に綮密な検査 の上，その周围 $1 \mathrm{~cm}$ 以上の筋層を含む切除が再発予防 の上にも有益溹のかも知れません. Morson 17.5\%，

Bockus 14\%に再発を見たと報告をしていますが，この 事実から術後の定期的な follow-up ほ重要でありま ఫ.

（21）癌化を伴った家族性大腸ポリポージスの 1家系について；とくにその病理組織学 的研究について

\author{
佼成病院外科 \\ 小金 沢 滋 \\ 東京大学病理
}

所安 夫

家族性大腸ポリポージスは優性遺伝する疾患で，また 30 歳以上は $90 \% ， 40$ 歳以上は殆ど 100\%癌に移行すると 云われて抒りま。

そこで演者ら汢本症の患者について，癌に先立つ病変 の存在を認識する目的で，昨年に引つゔき剔出した大腸 の粘膜面におけるポリープを全長に亘り 1 コも余すこと なく病理組織学的に検索した結果を報告する。

われわれの用いた大腸ポリープの組織学的分類は, 細 胞学的悪性度と変化の抎がりの大小加ら, 良性, 異型 I，異型II，異型III，癌の 5 段階に分けたものである.

患者は 25 歳主婦, 4 人姉妹の 3 番目で，直腸癌を伴っ た大腸ポリポージスで大腸全剔出術莱回腸㩲造設術をう けた。 父は直腸癌で死亡, 長姉は本年 2 月手術により 状結腸癌を伴った大腸ポリポージスと判明，妹は本年 9 月ロマノスコピー検盗により演者が值腸に少数のポリー プと認めた，すなわちここに家族性ポリポージスの1家
表 2 ポリープの大きさ(画径)と恵性度

\begin{tabular}{|c|c|c|c|c|c|c|}
\hline $\begin{array}{l}\text { 恶性度 } \\
\text { 直颈 } \\
(\mathrm{mm})\end{array}$ & $\begin{array}{l}\text { 良 } \\
\text { 性 }\end{array}$ & $\begin{array}{l}\text { 異 } \\
\text { 型 } \\
\text { I }\end{array}$ & $\begin{array}{l}\text { 異 } \\
\text { 型 } \\
\text { II }\end{array}$ & $\begin{array}{l}\text { 異 } \\
\text { 型 } \\
\text { III }\end{array}$ & 孺 & 計 \\
\hline$\sim 1.0$ & 79 & 26 & 7 & 7 & 0 & 119 \\
\hline$\sim 2.0$ & 148 & 163 & 153 & 56 & 12 & 532 \\
\hline$\sim 3.0$ & 31 & 40 & 81 & 44 & 9 & 205 \\
\hline$\sim 4.0$ & 2 & 5 & 10 & 25 & 4 & 46 \\
\hline$\sim 5.0$ & & & 5 & 3 & 4 & 12 \\
\hline$\sim 6.0$ & & & & 1 & & 1 \\
\hline$\sim 7.0$ & & & & 1 & 2 & 3 \\
\hline$\sim 8.5$ & & & & & 2 & 2 \\
\hline 計 & 260 & 234 & 256 & 137 & 33 & 920 \\
\hline
\end{tabular}

系を経験したことになった。

次に全大腸の剔出標本を腸間膜附着部の反対側すなる ち taenia librae と taenia omentalis との中央部を卵 開した全大腸の㘠を掞目にかける。

これは大腸の粘膜面に発生した腺腫性無茎性ポリープ

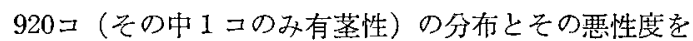
示すものである。すなわちポリープの悪性度と発生部位 との関係をみると悪性度の高いポリープが最も多くみら れた部位は下行結腸, $\mathrm{S}$ 状結腸, 直腸 $\mathrm{S}$ 状結腸移行部, 次いで横行結腸，上行結腸の順で方った。

唯一の有茎性ポリープはS 状結腸にみられるが，ての 先端は癌で, 根部に近づくにつれて異型开より異型II, 異型 I，良性の順にみられる。充た腸間膜附着部には他の 部位に拉けるよりポリープの発生分布が一般に少いこと が注目された，更にポリープに和ける変化よりそれにつ ふく大腸上皮粘膜における病変において，上り強い覀性 度のみとめられる場合がみられた。

表 1 ポリープの悪性度と発生部位

\begin{tabular}{|c|c|c|c|c|c|c|c|c|}
\hline \multicolumn{3}{|c|}{ 部位 悪性度 } & 良 性 & 異型 I & 異型 II & 買型 III & 癌 & 計 \\
\hline 直 & & 腸 & 13 & 9 & 12 & 7 & 1 & 42 \\
\hline 值 & S 状移 & 于部 & 1 & 3 & 12 & 22 & 0 & 38 \\
\hline$S$ & & 状 & 3 & 10 & 28 & 42 & 6 & 89 \\
\hline 下 & & 行 & 25 & 29 & 74 & 34 & 25 & 187 \\
\hline 脾 & & 签 & 14 & 27 & 26 & 1 & 0 & 68 \\
\hline 横 & & 行 & 124 & 63 & 43 & 18 & 1 & 249 \\
\hline 肝 & & 禁 & 11 & 10 & 10 & 4 & 0 & 35 \\
\hline 上 & & 行 & 59 & 74 & 37 & 7 & 0 & 177 \\
\hline 盲 & & 腸 & 10 & 9 & 14 & 2 & 0 & 35 \\
\hline 肛 & 門 - 虫 & 垂 & 0 & 0 & 0 & 0 & 0 & 0 \\
\hline & 計 & & $\begin{array}{c}260 \\
(28.2 \%)\end{array}$ & $\begin{array}{c}234 \\
(25.4 \%)\end{array}$ & $\begin{array}{c}256 \\
(27.8 \%)\end{array}$ & $\begin{array}{c}137 \\
(14.9 \%)\end{array}$ & $\begin{array}{c}33 \\
(3.6 \%)\end{array}$ & 920 \\
\hline
\end{tabular}


表 3 ポりープの発生部位と大きさ（值径）

\begin{tabular}{|c|c|c|c|c|c|c|c|c|c|c|}
\hline 直径 $(\mathrm{m} . \mathrm{m})$ & 直 腸 & $\left|\begin{array}{ll}\text { 直 } & S \text { 状 } \\
\text { 移行 部 }\end{array}\right|$ & $S$ 状 & $F$ 行 & 脾 筧督 & 横 行 & 肝 學 & 上 行 & 曾 腸 & 計 \\
\hline$\sim 1.0$ & 5 & 5 & 9 & 7 & 14 & 45 & 5 & 29 & 1 & 120 \\
\hline$\sim 2.0$ & 20 & 20 & 45 & 130 & 45 & 145 & 23 & 91 & 21 & 530 \\
\hline$\sim 3.0$ & 13 & 9 & 14 & 46 & 9 & 42 & 4 & 45 & 12 & 204 \\
\hline$\sim 4.0$ & 2 & 4 & 7 & 9 & & 13 & 2 & 9 & 1 & 47 \\
\hline$\sim 5.0$ & 2 & & 2 & 3 & & 2 & 1 & 2 & & 13 \\
\hline$\sim 6.0$ & & & & & & 1 & & & & 1 \\
\hline$\sim 7.0$ & & & 1 & & & 2 & & & & 3 \\
\hline$\sim 8.5$ & & & 1 & & & & & & & 2 \\
\hline 計 & 42 & 38 & 89 & 187 & 68 & 249 & 35 & 177 & 35 & 920 \\
\hline
\end{tabular}

次にポリープの大きさ(值径)と悪性度の関係をみると 悪性度の強いポリープほど，比べて一般にその大きさは 大であると云われているが，直径 $2 \mathrm{~mm}$ 以下の小さなポ リープでむ75コ（8\%）に悪性度の亮い異型而以上のポ リープがみとめられた．しかも良性ポリープとの肉眼的 鑑別は全く困難であった。

大腸各部位において，大小のポリープはほぼ均等に発 生分布している.

次に患者の姉の S 状結腸の切除標本では, 癌腫の近く に42コのポリープが双ら，その18コに異型川がみられ たが，癌らしきわのはみられなかった，次に患者の峬の ポリープ電顥像をお目にかける.5000倍の電顕像で軽度 の異型がみられる。古なわち核周辺部のクロマチン集 合, 核小体の不規則化，不明瞭な刷子線 (striated boarder)小数の微絾毛 (microvilli) などがみられ光検の所 見と一致している。

以上家族性大腸ポリポージスの1家系についてのべた が，とくに患者の剔出した全大晹に敌ける腺腫性ポリー プ 920コについて，病理組織学的検冞を行ない，そのう ち33コのポリープ $(3.6 \%)$ が癌であった，癌化ポリープ のみとめられた部位は下行結腸, S 状結腸, 直腸 S 状結 腸移行部直腸横行結腸で，この他異型亚のような異型度 のつよレポリープが上行結腸，盲腸部に少なからずみと ぬられた。

よって家族性大腸ポリポージスの治療として Ravitch の云う大腸全剔術および永久的回腸瘦の造設が強調され ているが, 直腸・結腸の一部に癌がみとめられる場合は 少くとも大腸全剔術が最も合理的であると考える.

\section{質問} 細 谷万夫

722 コポリープ中, 散在性に上, 横, 下行結腸に癌化 したポリープをみるがその中には可成り良性のポリープ をみる、この良性ポリープは一般の大腸ポリープと異っ ているか，またこの良性ポリープは将来癌化の傾问ある
と㧍考えになるや否や.

東大所先生の全ポリープを御検鏡になった御感想をい つの日かお聞きしたい。

本例はポリープが癌化の道をたどる貴重な御研究と思 われますので.

答 小 金 沢 滋

臨來家には専門すぎて大変難しい質問です，ただ 25 歳 のこの患者が生後より25年間にこの様な無数のポリープ が大腸に群生する事実は単なる食物の通過もしく注胆汁 酸その他の化学物質の刺激のみで起りらるとは到底考え られないことで，ここに遺伝性因子の存在が考えられる わけである。

この点共同研究者，所も強調していることを申し上げ ます。

（22）直腸癌を伴なった家族性結腸ポリポージ ス

$$
\begin{array}{r}
\text { 東北大学 楨外科 } \\
\text { 金 子靖 征 }
\end{array}
$$

最近, 6 人兄弟の5ち, 長男, 長女, 次女の 3 人に, 直腸嵒を伴った結腸ポリポージスの発生をみた 1 家族を 経験しましたので，これらに関係した 2,3 の問題につ いて検討を加えて報告します。

家族は農業を家業としており，家族歴では父が腸疾患 で40歳で死亡している他は，特記すべきことはなく，ま たここで報告する 3 人を除いた他は，現在，それぞれ健 康であります。

症例 1 は長男, 43歳であります.

約 $5 \sim 6$ 年前から年に $2 \sim 3$ 回の下血があり, 某医で内 痔核の診断を受访，坐薬を使用していをしたが，約 4 力 月前より，肛門部痛がおこり，更に下血が増恵したため 来院しました。 
直腸指疹, 直腸鏡検查で, 肛門輪より $2 \mathrm{~cm}$ より $7 \mathrm{~cm}$ までの深さで, 前壁を中心に広基性の㣴癔を有する可動 性の腫瘤を認め,さらに, その周辺に数コの有茎性ポリ ープを認めました。

レ線検查では, 直腸の腫瘤に一致して陰影欠損があり， 結腸全体にも，多数のポリープ様陰影が認められまし た．直腸腫瘤よりの細胞診でも癌細胞陽性であり，直腸 癌を伴った結腸ポリポージスとして手術を行いました。

手術所見では, 癌腫は超鶏卵大, 直腸下端の前壁より 左側に位置し，可動性がありました，肝転移はありませ んでしたが，管腹大動脈リンパ節は硬く腫張し転移あり と思われました。結腸全体に大豆大のポリープを無数に 触知し，特にS 字状結腸には，くるみ大の腫瘤を認めま した，以上の所見より，腹会陰式に直腸切断，および恶 全結腸剔除術を行ない，右下腹部に結腸㸌を 造設しま Lた.

剔出標本汁肛門より $2 \mathrm{~cm}$ の所に $7 \times 5.5 \mathrm{~cm}$ の潰場形 成の腫瘤があり， $\mathrm{S}$ 字状結腸に有茎性の巨大ポリープ， その他，結腸全体に無数のポリープを認めます。

組織学的には，值晹部腫瘤は腺癌であります，他のポ リープは腺腫性ポリープで悪性変化の所見はありませ ん. 術後45日で退院, 現在, 結腸瘦より出血もなく経過 観察中であります。

症例 2 は, 長女, 34 歳です。

約 2 年前から, 下血と肛門痛があり, 某医で 2 回内痔 核として手術を受けています５力月前上り便柱が細く なり, 出血も強くなり下腹部痛, 全身倦忠, 贏瘦, 貧血 む加わり来院しました，直腸指診，直腸鏡検查で肛門輪 より $5 \mathrm{~cm}$ 加ら $10 \mathrm{~cm}$ の梁さで，左側壁中心にほぼ全周 に互る潰济を形成した腫瘤を認めむした，わずかに可動 性があり, 子宮口, 胵への浸潤はなく, 膀脱鏡検查でも 正常でした.

レ線検查で，腫㓪に一致した陰影欠損があり，結腸に も数コのポリープ樣陰影が認められをす，尚，腫溜より の生検で腺癌と判明し，直晹癌を伴った結腸ポリポージ スとして手術を行ないました，手術所見は，直腸下部に 鷄蛳大の腫瘤を認めましたが，周囲への浸潤や，肝転移 もありません，結腸全体にびまん性に多数のポリープを 触知しました，以上ょり，腹会陰式に直腸切断，全結腸 剔除術を行ない，回腸獀を造設しました。

剔出標本は，直腸下部に癌腫があり，結腸全体に大豆 大のポリープを多数認められました.

組織学的には直腸の腫瘤湶滛で,ポリープは腺腫性 ポリープで細胞の配列む整然として悪性所見はありませ 几.

しかし，本症例は術後 3 年で癌再発のため死亡しまし
た.

症例 3 は次女，28歳であります。

約 2 力月前から下血に気付いていましたが昸痛なく放 置していたところ，次第に下腹部痛が起こり某医より直 腸癌の診断で紹介されてきょした。

直腸指診, 直腸鏡検查で肛門輸より $3 \mathrm{~cm}$ の前壁にく るみ大のポリープ状の腫瘤を認め可動性大でありまし た、これょり直腸輹の診断で, 腹会陰式に直腸切断, 結 腸搜造設術を行ないましたが, 剔出標本を開いたところ, 標本全体に大豆大のポリーブがあり，結腸ポリポージス と判明しました。

組織学的には, 直腸の腫溜は腺癌で, 多くのポリープ は腺腫性ポリープでありました．現在術後12年になりま すが，結腸慺より出血もなく健康に生活してます，

遺伝性疾患としての家族性結腸ポリポージスは1882 年, Cripps によって初めて報告され，以来，欧米では 本症の報告が多数みられますが，わが国では稀で，われ われの教室でも今回報告した 1 家族の 3 例のみでありま す.

本症の覀性変化は, 非家族性のポリポージスに比し， 可成り高率に認められます. 從来, 癌とポリープが共存 する傾向があり，好発部位が似ているなどの理由で，ポ リープの癌化を肯定する考えが多くありますが，われわ れの教室で経験したポリープを併存した直腸癌27例のう ち, その癌型が腫瘤型であったものは13例あり, ポリー プの相当数が癌化するものと考光ておりせす。

結腸ポリポージスの治療方針は，現在，多く行なわれ ているものとしてスライドに示すものがありますが，そ れらの他, 悪性化し易い, 直腸拉よび下部結腸をふくめ て切除する方法があります。家族性結腸ポリポージスの 場合悪性変化を併う場合が多いため, 直腸切断, 全結腸 剔除を行なうべきだと思います．Berk らも上位結腸に ポリポージスの所見を残した場合，覀性化の傾向が強い ため, 見つけ次第, 積極的に再切除するか, 電気焼灼に て处理するように述べています。しかし，手術侵襲の 大きさ，術後の水分代謝のことを考慮す㞦ば覀性化の認 めない場合, 肛門括約筋の機能を保存することを考慮す べきと考えています，乙かし，この場合，術後の定期検 診を必ず行ない，経過を観察することが大切と思われま す.

われわれの症例では，第 1 例に広沉結腸，直腸剔除術， 第 2 例飞全結腸, 直腸剔除術, 第 3 例に S 字状結腸, 直 腸剔除術を行ないましたが，第 2 例が術後 3 年で虞再発 で死亡しました. 残り 2 人にっいて，どのような変化を とるか目下経過を钼察中であります。 


\section{（23）若年者大腸癌について}

大阪大学附属病院第 2 外科 陣内伀之助, 安富 正幸

一般に癌は年令々密接な関倸があり，50～60歳代のい わ河る“癌年齢”に好発し，若年者には少ないこと，ま た若年者に発生した癌がより悪性であることは衆知の事 実である．大腸澏についても同様なことがいえるが，60 歳前後のどちらかといらとやや高龄化好発し，その予後 む比較的良好であって，最近の報告に上ると結腸癌で60 \%. 值腸癌で $50 \%$ 以上の 5 年生存率を示している，とこ ろが，若年者の大腸癌は予後が覀いことは知られていて も，その頻度が少ないため，わが国は勿論，欧米におい ても詳細な検討はあまり行なわれていない，そこで，19 53年より68年までの大阪大学第 2 外科と 1948 年より 62 年 までの岡山大学陣内外科でわれわれが経験した症例をも とにして著年者大腸癌について検討を加えた。この間の 大腸癌は462例で, このうち29歳以下の若年者癌は26例, $5.6 \%$ ある。.これを内外の文献にみられる若年者大腸 癌の頻度について検討してみると，欧米の若年者大腸癌 の頻度にくらべわが国の頻度は幾分高くなっている，っ まり，わが国では欧米に比べ大腸癌そのものは少ないが， 若年者癌の占める頻度は逆に高いといえるのではない かと思われる．若年者大腸癌26例についてその局在部位 をみると，下行結腸から直腸に加河て分布している，ま た年齢的には26例全部が20歳より29歳までに分布し，男 17例，女9例で男女比恃大体 $2: 1$ と大腸路全体の男女 比と大差はない，病脳期間については，年令と関倸なく 過半数が発病後半年以内に，大部分が 1 年以内に入院手 術を受けており，若年者癌に特別なことはない.入院時主 症状については若年者では73\%に粘血便あるいは血便の ごとき出血があり，排便困難を新えるものが $37 \%$ と対照 群に比べやや多いことが目立つが，これは前述のごとく われわれの若年者例が下行結腸以下に限って分布してい るためであろうと思われる。根治手術についてみると， 20歳代では症例数が少ないばかりでなく，その中での姑 息手術の割合も多く，これを根治手術率でみると大腸癌 全体の平均根治手術率が $80.6 \%$ であるのに，29歳以下の 若年者では26例中 16 例に根治手術が行なわれ，根治手術 率はわずかに $61.5 \%$ あって,30歳代，40歳代がそれぞれ 85.7\%，86.8\%であるのに比べ，はるかに低いばかりで なく，70歳以上の高踦者の76.0\%よりもさらに低い根治 手術率である. 次に生存率をみると大腸癌入院患者全体 については平均 $40.8 \%$ の 5 年生存率であるが, 若年者で
は $23.8 \%$ とかなりの羑がある. また根治手術後の 5 年生 存率をみると，大腸拈全体の $52.3 \%$ に比べ若年者では $33.3 \%$ とかなり低い值を示している，以上の結果より大 腸癌においては若年者例では根治手術率が低いばかりで なく, 根治手術施行後の予後も極めて雭いといらことが いえる．逆に根治手術が不可能であった症例についてこ の理由調べると若年者では腹腔内播種が多いというこ とが目立つが，原因の明らかな根治手術不能例はわずか 9例しかないのではっきりしたことはいえない．

癌腫の肉眼的所見を限局腫瘤型, 潰瘍型, 中閒型执上 び浸潤型に分類すると若年者では対照群に比べて限局型 が少なく浸潤型が多い.Dukesの分類により癌の進行の 程度を比較するとリンパ節䎐移のない Dukes AとBが 大腸癌全体については $13.7 \% ， 32.6 \%$ である゙若年者で は 7.7\%，19.2\%と少なくて，リンパ節転移のあるCが 全体の $53.7 \%$ にたいし $73.1 \%$ と比率が多くなっている.

組織学的には若年者では末分化な単純澞が対照群に比 べると若干多いようだが，大腸癌の大部分が腺癌で単純 癌は少ないことから明らかな比較はできない，そこで贯 癌研究会の基準に従って細胞異型度, 組織排列の異型度, 浸潤度の分類を試みた．若年者群では対照群に比べて， 細胞，組織とも異型度の強いIIIが多く，さらに浸潤度に ついても浸润性の強い $\gamma$ 型が約半数に達している。これ らの異型性，浸潤性を検郡し得た若年者例が11例しかな いので，確定的なことはいえないが，細胞，組織の異型 性がつよく浸潤性がつよいことが若年者大腸虞の予後が 不良である重要な原因の1つではないかと考えられる。

次に手術々式についてであるが，われわれは従来より 結腸癌に対して横行結腸中部より右半のものには主とし て結腸右半切除を，中部以下のものには結腸部分切除を 行なっているが，3例の若年者結腸癌はいづれも下行結 腸以下に亦り，部分切除が行なわれ，2例が 5 年以上生 存している。一方，直腸癌に対しては近年症例を選んで できるだけ自然肚閒術式を行なうように努力しており， 1953年以降では直腸癌根治手術例の約半数に自然肛門術 式を行ない人工肛門術式と同じ 5 年生存率が得られてい る. 若年者直腸癌については根治手術 13 例中 3 例仁自然 肛門術式が行なわれているにすぎないこれは自然肛門 術式を採用する以前の症例が多かったことのほか，若年 者の直腸癌の浸潤性が強いために自然肛門術式の適応外 であったためと考えられる。しかし自然肛門術式を行な $っ た 3$ 例,つまり anterior resection 1 例と, pull-through 2 例のうち, 5 年生存中のものが 1 例, 3 年以上生存中

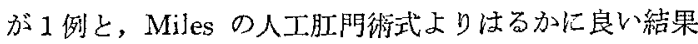
を示しており，症例は少ないが適応を正しくすれば自然 肛閒術式も良好な結果をもたらすものと考えられる。 
以上われわれの経験した若年者大腸癌について検討を 加えたので報告した。

\section{（24）結腸，直腸癌の早期症例について}

東京大学石川外科

○土屋，周二, 加賀美 尚, 桐淵 義康
山本 登司, 草 閐 悟

近年胃癌, 乳癌などについては診断, 治療が向上しい わゆる早期癌も稀ではなくなったが, 結腸, 直腸癌につ いてはまだ進行癌が大多数を占めている，われわれは最 近6力年間に東京大学石川外科酒した原発性結腸・ 直腸癌症例のなかの比較的早期と抢もわれる症例につい て検討を加えた. 発癌加ら治療までの時間的関係から癌 が早期のものであるか進行したものであるかを論ずるの は澏の発育速度が扔のおのの例によって相異る点などか ら困難であり，胃癌においては胃壁内人の侵潤の深さか ら一応いわゆる早期癌, 進行淣を区別する方法が現在広 く行なわれている.癌治療方法の選択，予後判定などの面 からみて結腸・值腸癌においてもこれと同じ区別が有用 であるかどうかは簡単にはいえない:これまでは深達度 とリンパ節転移を組合わせた Dukes 分類が広く行われ かなりその奏用性が認められている：われわれはこの発 表において一応いわゆる早期胃癌の概念に準じて結腸・ 直腸の粘膜または粘膜下層に止るものをいわゆる早期癌 とし，さらに固有笳層の比較的表層に止るものを加えて これらを比較的早期症例と仮称しこれらの壁内の比較 的浅層に止まるものの特徴について検討した（以下部 位， $\mathrm{P}, \mathrm{T}, \mathrm{G}$ などは UICC 分類による) なお Tについ ては直腸のものを結腸にも用いた。

結腸・直腸癌の症例はこの期閒中におのおの55例（男 33 例, 女22例, 平均年令 57.2 歳), 80例 (男53例, 女 27 例, 平均年齢57.5歳) であり，切除率々それぞれ 47 例 (85\%)，52例 $(68 \%)$ ，切除例のらちいわ河る治癒手術 はそれぞれ切除例の $78 \%$ (全手術例の65\%)，84\%（58 \%)であった.

比較的早期症例はすべて治癒手術が行なわれたもので 上記の定義に従うと, 結腸癌では 6 例あり,このうち, (1) 粘膜屯たは粘膜下層に迆るもの $\left(\mathrm{P}_{1}, \mathrm{P}_{2}\right) 1$ 例, (2) 固 有笳層の表層に止まり，しかも腫湟の大きさが全周の $1 / 3$ 以下のもの $\left(\mathrm{P}_{3}\right.$. ただし固有筋層表層まで. $\mathrm{T}_{1}$, ただし大 きさのみについて, UICC 分類では $T_{1}$ は筋層浸潤はな いものとしている.) 0例，(3) 深さは(2) と同じであるが 大きさが全周の $1 / 3$ 以上のもの $\left(\mathrm{P}_{3}\right.$. ただし筫層表層まで, $\left.\mathrm{T}_{2}, \mathrm{~T}_{3}\right) 5$ 例であった. 直腸煰では上と同様に分類して 8 例あり，（1）４例，（2）1例，（3）３例であり，胃癌
のいわゅる早期癌にあたるは直腸癌に多かった（以下 (1)，(2)，(3)は上記に従う。)

癌の部位別にみると, 結腸癌の発生部位は Region (a) 31例，(b) 8 例，(c) 1例，(d) 15例で，おの沶のの切 除例（カッコ内は治澺手術例）は30 (26)，8（7），1 (1)，9（5)例であった.このうち早期症例は Region （a）に(3)が 4 例，(b)に(3)が 1 例，(d)に(1)が 1 例あ った.

直腸癌では Region (a) 29例, (b) 48例で, 切除例 (カッコ内は治漓手術例)は16 (15)；36 (29) 例で, Region (a) に(1) が 3 例，(2)が 1 例，(b)に(1) が 1 例 (2)が 3 例み上められた（1) は直腸および S 字結腸に多 く上部結腸にはみられなかった。なおこのほかにいわゆ る早期例が 重複随伴した 進行癌が 3 例（結腸 1 , 直腸 2)あった統計からは除外した.

主要初発症状と癌の部位や, 比較的早期例発見との関 係をみると, 結腸癌では一般に便通巽常, 腹痛などの漠 然とした症状が多く、いわ河る早期例でもこのような訴 えをもつものが多かったが， S 字結腸の(1) の症例では 出血を主症状とした. 直腸癌では一般に血便. 便通異常 などはつきり自覚しやすいものが圧倒的に多く、いわゆ る早期例の大部分がこれらを初発主症状とした。

病兴期間についてみると結腸癌の多くはその症状がは じめは漠然としているのでその時期が明かではない点も あるが, 6 カ月以下のものもこれをこえるものも切除率, 治瘾切除率に大差はなく，また 6 力月をこえるものにも いわゆる早期症例が 4 例みとめられた。 これはまた癌の 登育速度が一定せず，それがゆっくりしているものも早 いものもふくまれるためでもあろう。たとえ壮 S字結腸 の(1)の症例は 4 年閒にわたって出血をみている，直腸 癌では出血の上らに症状初発がかかりやすことが多いの で病悩期間が比較的きややすいと打もわれるが，3カ月 末洲のものでは切除率, 治痛手術率が $3 \sim 6$ 力月のもの よりかなり高く、またい放化る早期症例も 3 力月未澫の ものに多かった. しかし6カ月をこえるものではそれと 以前のもの全体に比して大差ない切除率・治澺手術率を 示していることが注目される、このことはやはり癌の発 育速度の比較的緩慢なものの存在を示すものであろう。

つぎにいわゅる早期症例の診断確定はどのようにして 行なわれたか検討すると, 結腸癌では(1)の1例が出血 を主訴としS字結腸鏡で発見されたが，他はレ線診断な どで確定されてをり，しかもすべて(3) ( $\left.\mathrm{P}_{3}, \mathrm{~T}_{2,3}\right)$ で 真の意味の早期であるかどうか疑わしいものが多か。 た. また 1 例は習慣性腸重積症をおこす盲腸癌で症状が 明かなため検查がすすめられ比較的早期 $\left(\mathrm{T}_{2}, \mathrm{P}_{3}\right.$ 筋層 表層)に発見されたものであり，他の1例はときどき右 
下腹痛をおこしいわゆる慢性虫垂炎として虫垂切除をう けた症例で，虫垂を組織学的に検索したところ想性ムこ ツェーレ (mucinous cystoadenocarcinoma) が発見され た症例でいずれも特殊なものであった。これらをのぞく と早期症例を発見するために泣鞋微な症状のう台積極的 に結脂のレ線検查，内視鏡検查等をくわしく行なう以外 にはなく実際的にはかなり困難老伴うものと思われる。 直腸癌のい打る早期例についてみると (1) $\left(P_{2}, T_{1}\right)$ の ような小さい腫瘤の発見はす心゙て軽度な血便について積 極的に直腸鏡検圭と生検を行なったため可能であったも のである、1例は無痖状であったがいわゆる人間ドック

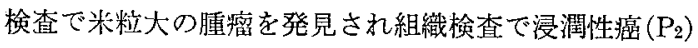
であることが判明した症例であった（2)，(3)の症例は 指疹, 直腸鏡で診断された.

つぎにこれらいわゆる早期症例の手術所見および摘出 標本の所見を他のものと比較検討した．結腸癌全切除例 47例中 Dukes A は6 例（13\%）で上述のいわゆる早期 例は noですべてこれに属し，Bは20例(43\%)，C21例 (44\%) であった。 Borrmann 分類では I 型 2 例，II型 27例，III型17例，IV型 O（このほか蛙垂炎性ムコツェー ル 1 例) で, 早期例の 1 例は (1)のは I 型, 3 例は II 型，1 例はIII型であった. $\mathrm{P}$ は $\mathrm{P}_{1} 1$ 例, $\mathrm{P}_{2} 0, \mathrm{P}_{3} 21$ 例， $\mathrm{P}_{4}$ 25例で，いわ西早期例は $\mathrm{P}_{1} 1$ 例， $\mathrm{P}_{3} 5$ 例となり, $\mathrm{S}$ は $\mathrm{S}_{0}$ 12例, $\mathrm{S}_{1}$ 12例， $\mathrm{S}_{2}$ 19例， $\mathrm{S}_{3} 4$ 例で早期例 は すべて $\mathrm{S}_{0}$ および $\mathrm{s}_{0}$ であった。 值腸癌全切除例52例で は, Dukes A 8 例 (15\%), B24例 (46\%), C20例 (38 \%) でいかゅる早期例の 6 例はAに愿し，2 例は $\mathrm{n}_{1}(+)$ のためCに属することになった. Borrmann 分類では I 型 4 例，II型30例， III型17例，IV型 1 例で，早期例では I 型 4 例 ((1) が 3 例)，II 型 8 例（(1)が 1 例，（2）が 1

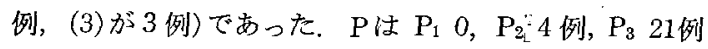
$\mathrm{P}_{4}$ 27例で, いわゆる早期例では $\mathrm{P}_{2} 4$ 例, $\mathrm{P}_{3} 4$ 例であ った. $\mathrm{S}$ 注 $\mathrm{S}_{0} 21$ 例 $\mathrm{S}_{1} 5$ 例， $\mathrm{S}_{2} 20$ 例， $\mathrm{S}_{3} 6$ 例で早期 例はすべて $\mathrm{S}_{0}$ および $\mathrm{s}_{0}$ であった。、いわゆる早期例の 組織分類では結腸直腸のおのおの1例（いずれも(1)が $\mathrm{G}_{1}$ であった他はずへて $\mathrm{G}_{2}$ であった

いわゆる早期例に対する治療成績はまだ術後期間が短 いので十分検討できていないが，結腸澞ではすべてに結 腸部分切除を行ない，(3) の 1 例(Region (b), $\mathrm{T}_{3}, \mathrm{P}_{3}$ 筋層表層）の9力月後局所再発で死亡している他はすべ て 4 年 9力月生存している. 死亡した一例は一虑侵潤 が固有筋層表層に止ってはいたが 手術時結腸間膜に膿 瘍形成がありかなり進行したといってよい症例であっ た. 直腸癌については（1)で米粒大の小腫瘤のあった 1 例に括約笳肛門保存貫通術式を行なったが，他にはすべ て.Miles 手術を行なった.このうち死亡したものは 2
例で，他は 6 年 1 年後生存している。死亡した 2 例の うち 1 例は (1) ( $\left.\mathrm{T}_{1}, \mathrm{P}_{2}\right)$ であるが $\mathrm{n}_{1}(+)$ のので $1 \frac{1}{1 / 2}$ 年後死亡し, 他の 1 例は (3) $\left(\mathrm{P}_{3}, \mathrm{~T}_{3}, \mathrm{n}_{0}\right)$ の症例で 3 年後 肝転転移で死亡した. $\mathrm{P}_{1}, \mathrm{P}_{2}, \mathrm{~T}_{1}$ 程度の直腸癌に 対し て行う手術術式はたとえ腫瘤は小さくても癌組織は多く は粘膜下層へ向、侵潤性発育を行うので当然局所的腫瑠 切除仕不可であり，またわれわれのいわ蛒る早期症例の なかにも $\mathrm{T}_{1}$ で $\mathrm{n}_{1}(+)$ のものが 2 例あった点などから 直腸周囲組織をふくめた直腸切除が必要であると抄もわ れる．貫通術式にするか Miles 法にするかは主として 腫瘤の部位によってきめるべきであるう，ただ高龄者や 他の合併症を伴うものについては局部的切除で妥協しな ければなら婸合もあるとおもわれる。たとえば統計期 間外症例であるが，78歳で心管梗塞のある $\mathrm{P}_{2}, \mathrm{~T}_{2}$ のを のに Miles 手術を行い術後早期に死しした例をはじめ, これまでの症例で一般に 70 歳以上の高龄者では Miles 手術後の早期死亡例がかなり多かった（40〜50\%・80歳 以上ではとくに多い）点等も十分考虑すべきであろう.

以上比較的早期結腸直腸癌として， $\mathrm{P}_{1}, \mathrm{P}_{2}$ ，および $\mathrm{P}_{3}$ で固有筋層の比較的表層にとどまる症例について検討を 加えた。 これらの症例は比較的少い. $\mathrm{P}_{2}$ 以下のものは ほとんどがS字結腸と直腸にみられたポリープ状小腫瘤 であり全結腸直腸癌の135例中 5 例にみられたにすぎな 、ここれらはいわ的る早期胃癌のI型に対比すべきもの であるが，II型，而型にあたるむのはみられなかった。 結腸・直腸癌については壁内浸潤の梁さからいわ仯る早 期癌を定義するのがよいか, 腫瘤の大きさなどの他因子 を加える方がよいか今後検討を加える必要があるとおも われる。なおこれら症例の臨床上, 病現上の特徴と手術 方針についても論じた.

発言 坂 本 俊 雄

過去 6 年間に我々は原発性結腸癌 35 例, 原発性直腸癌 59 例を経験したが，そのうち 3 例は UICCのP2 即ち 癌浸潤が粘膜下層に止まっている症例であった。

癌浸潤が粘膜下層に止まっている症例は結腸跒では 35 例中 1 例で血便を主訴とし結腸ポリポージスの骖断のも とに全結腸切除術を行ないS 状結腸部のポリープ状牌瘤 が組織診断で腺癌と判明した症例で術後 2 年経過した現 在も健在である。

直腸癌では59例中 2 例で主訴法ともに血便で 1 例は直 腸鏡で肛門輸より $6 \mathrm{~cm}$ 内方に大豆大のポリープ状腫瘤 をみつけ組織診断で腺癌とわかり1力月後に真腸切断術 を行なった所, 切除組織標本ではポリープ部の上皮細胞 の配列の乱れと mitotic figure のみがみられる症例で 術後 3 年半の現往健在である.

他の 1 例は直腸鏡で肛門輸より $14 \mathrm{~cm}$ の部に拇指頭大 
の半球大のポリープ状隆起があり切除組織標本で癌浸潤 は粘膜下層に止まっている腺癌で術後 1 カ月半の症例で ある。

以上我々は 3 例の癌浸潤が粘膜下層にとどまっている 症例を経験したので報告する。

\section{追加}

坂本俊雄

過去 6 年間に我々は原発性結腸癌35例原発性直腸澺59 例を経験したが，てのうち 3 例は UICC の $\mathrm{P}_{2}$ 即ち癌 浸潤が粘膜下層に止まっている症例であった。

\section{（25）結腸癌・直腸癌再手術例の検討}

慶大外科島田信勝教授

○植松 義和, 大場 正己，赤松 隆 輏原 徳之, 小平 進, 三村 孝 植草 実

結腸癌は悪性度の低いものが多く，切除率が高いこと から手術の予後は比較的良いといわれていますが，手術 成續向上のためには，なお多くの問題が残されていま す. 一方直腸癌では, 発見のおくれ, 解剖学的特殊性か ら予期した手術成續を挙げ得ないのが現状であります。

根治的手術が可能であった症例でも再発が疑われた り，何らかの合併症のために再入院を余儀なくされる症 例は少なくありません。

これらの治療に当っては、な括多くの困難があります。 われわれは, 今回このような結腸癌, 直腸癌の再入 院，ことに再手術例について検討し，治療上の二三の問 題を論じたいと思います。

昭和 32 年より 43 年までの 12 年間に慶大外科に入院した 結腸癌, 直腸癌は 400例で, このう古再入院症例は 120 例であります，再手術例は57例で，再入院例のほぼ半数 を占め, 再発が26例, 胃癌, 子宮癌などか，らの続発が 17例，非再発例は14例であります。

結腸癌からの再入院は40例で, 初発結腸癌 106例に対 して $38 \%$ にあたり, 直腸癌からの再入院は56例で, 初発 直腸癌 174 例の $32 \%$ であります。

結腸癌再発は34例で，再手術が可能なことが多く，半 数に再手術がおこなるれています，直腸癌からの再発は 36例で，うち9例，ほぼ4分の 1 亿再手術がおこなわれ たのみであります，胃癌からの続発例は全例に，また子 宮癌からのそれは10例中 8 例に積極的に再手術がおこな われ，再手術の可能性が高いことが示されました。

一方，非再発例は全例が，術後合浒症あるいは後遺症 によるものでありますが，再手術を必要としたものは直 晹癌手術後に多く，初回手術は慎重に和こなうべきであ ります。
癌再発形式についてみますと, 結腸癌34例中吻合部再 発と考えられるものが10例，30\%を占め，9例に再手術 がおこなわれていますが，病変部を含めた広範囲腸切除 の必要性が反省させられました，癌性イレウス，癌性腹 膜炎などの腹膜播種は最も多く，13例，38\%にみられま したが，再手術の機会は少なく，4例にイレウスに対す る手術が抽こなわれたのみで，他はすべて再手術が不可 能でした。 異所性重複癌は, 明らかに再発と認められた もののほかは再発とはいえませんが，一忘再発例として 検討しました。 これ䛉該当するものは 4 例で，うち 3 例 に再手術がおこなわれています。

直腸癌からの再発は腹膜播種, 会陰再発がそれぞれ 9 例で最も多く,これらに次いで肺転移, 泌尿器への転移 となっております、結腸癌再発に多くみられた腸管再発 が直腸癌に少ないのは再発形式からみて当然であり, 従 って再手術の可能性が少なくなって拉ります。非再発例 では人工肛門内障害，イレウス，瘦孔などが主な合併症 であり，人工肛門狭窄例は術後平均 5 年を経てから再手 術が㧍こなわれ，人工肛門造設のむずかしさを示してお ります。

次は再発手術例の主訴及び主症状についてですが，結 腸癌では腹痛, 腹部膨満, 腹部腫瘟, 嘔気, 嘔吐等の腹 部症状を呈するものが最も多く；やせ・賓血などの全身 症状が認められたものがこれに次いでおります，便秘， 下峲，下血などの便通異常を示したものは 1 例もありま せんでした，結腸癌の手術後に便通異常を訴えたとき は，それが再発によるものであれば再発術は先ず不可能 と考えられます。直腸癌では腹部症状と便通異常が，そ れぞれ $46.6 \%$ で二主訴をなして扔ります。

続発癌では，主として腹部症状，便通異常などの腸管 再発を示唆するものが多いが，同時に，少数例にではあ りますが, 尿路障害, 腰痛, 発熱などの多彩な症状も認 められました。

再手術の内容については, 結腸癌からの再発10例に腸 切除がおこなわれ，左結腸潞では 6 例中 5 例に腸再切除 が可能でした，直腸嵒では 4 例に，さらに続発癌でも 7 例湯切除が掞こなわれて，再発・続発例43例のうち21 例，約半数に腸切除がおこなわれたことになります。非 再発例では合併症に対してそれぞれ適正な手術がおこな われています。

腸切除を術式別にみると，右半結腸切除が 9 例, 部分 切除 8 例, 腹会陰式直腸切除が 3 例で, 積極的な手術が おこなわれていることが判ります。初回手術から再発手 術までに経過した期間は，結腸澏では平均 1 年10ケ月で すが, 異所性重複涭では平均 3 年 7 力月と非常に長い経 過を示しております。 
再発手術例の初発病変につけて Dukes 分類を適用す ると, 結腸癌では B C Cがそれぞれ半数を占め, 直腸癌

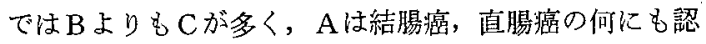
められ安せんでした。

再発手術例の予後をアンケートにより，86\%の回答率 を得て分析しましたが，腸切除例では, 術後 6 力月の生 存率は $52.7 \%, 1$ 年後には $47.4 \%$ とほぼ半数近い生存を 示し， 2 年後でる $17.8 \%$ の生存をみました. 最長の長期 生存例は, 再手術後 8 年 4 力月の現在元気であります. その他の手術とは, 吻合, 人工肛門造設, 単開腹などの 姑息的手術に止どまったものですが， 3 力月後の生存は $30 \%$ で，1年後には 1 例が生存するのみでした。平均余 命は 3 カ月しかなく, 延命効果は明らかではありませ ん。しかし苦痛を軽減させて余命を全うさせるためには 再手術は考慮される洒值があります。

癌治療成績向上のためには, 早期診断, 早期治療が第 1 に重要であることは申寸までもありませんが，手術後 は定期的に臨床症状をチエックし, レ線検查, 内視鏡検 查で follow up することが大切であります. 再発が疑わ れたときは積極的に再開腹, 再切除の可能性を迫求する ベきであります。

以上,われわれの, 積極的におこなった結腸癌, 直腸 癌再手術例の成績を報告しました。

\section{（26）結腸癌の遠隔}

岡山大学田中外科

遠藤 俊明, 竹馬 浩 戸谷 拓二, 岡島 邦雄

消化器系の癌の中で, 結腸癌の術後遠隔は比較的良好 であります。これ洁腸が解剖学的に隣接臓器と疎遠で 血管・リンパ系も比較的単純で外科治療に向いているこ とまた腫瘤が限局性で発育が緩慢なものが多いことに よるものと考えます。

しかしながら，胃癌に較べるとその発見は非常に遅れ て抢り，私たちの64例の症例の中では所謂早期癌は僅か に2例であります。

そこで，更に遠隔成績向上のためには如何にす心゙きか 術後遠隔に検討を加えてみました。

昭和 30 年から昨年まで術後 1 年以上の結腸癌 Primary case 64例中, 切除手術を行なったものは58例で切除率約 $90 \%$, これは私たちの胃癌の $72.2 \%$, 直腸癌の $78.3 \%$ に 比べ高率であります，年龄構成は29歳から80歳までにわ たり, 平均年龄55歳, 男女比 $2.3: 1$ で男に多くこれら は癌研梶谷博士らの報告と略々同じであります，部位別 にみると盲腸, S 状結腸に比較的多く,ついで横行結腸
の順であります。

なお S 状結腸の区分については，臨床的に便利な腹膜 転部より上方 recto-sigmoid を $\mathrm{S}$ 状結腸に入れておりま 才.

発生部位別に肉眼型をみますと，限局型が $2 / 3$, 中間型 が $1 / 3$ ，浸潤型は僅か 3 例にすぎません，術式別にみます と、スライドのと打りとなり，姑息的手術に終ったもの は平均して 7 カ月後に全例死亡いたして㧍ります，直接 死は 3 例で $5.2 \%$ であります。

さて遠隔成績をみますと, 術後 1 年以上を経過した58 例の切除群の中，現在生存して抢るものは28例でで約半 数, 3 年遠隔は 46 例中 22 例で $47.8 \%, 5$ 年遠隔は 28 例中 13 例 $46.4 \%$ となりこれをグラフで示せば 1 年で $60 \%$ 台に 落ち，あとはゆるやかなカーブとなります。

10 年以上経過例注 13 例あり,中 5 例は 3 年以上, 4 例 が10年以上生存しております.

5 年生存を，わたくしたちの胃癌の $50.3 \%$, 直腸癌の $41.4 \%$ と比較すれば，結腸癌はその殆んどが advanced type であることを考えるとき，遠隔成續は良好といえ ましょう。

これを諸家の成績と比較すれば，スライドの通りであ ります，発生部位別に遠隔をみますと，1 年以上生存を 小さなO， 3 年以上を○で表わせば， $\mathrm{S}$ 状，横行，上行 結腸が比較的成績良好で, 隣接臟器の合併切除を余儀な くされた肝彎曲部の癌や, 狭窄症状を示すほどに進展し たものが多かった盲腸癌に掠いて予後不良でありまし た．ちなみにStenose を呈し緊急手術をした症例は58例 中実に21例に及びそれらの遠隔は 1 年以内死亡が半数, 3 年以上生存したものは $30 \%$ にすぎまん。

さて TNM 分類にこれらをあてはめてみますと， Tumor の性状Tでは, 癌腫が $1 / 2$ 周以上を占めるが隣 接臓器には及んでいない $\mathrm{T}_{3}$ が約半数, 隣接蔵器浸潤が ある $\Upsilon_{4}$ が半数となり，手術時 nakroでリンパ節転移

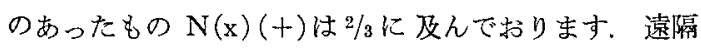
転移Mは，あったもの $\mathrm{M}_{1}$ が 8 例でこれは全例死亡致 しております。スモール $\mathrm{n}$ 群については，今後険索し てゆく必要を感じて招ります。

癌の進展度 Pについて云えば， $\mathrm{P}_{2}$ が僅かに 2 例，筋 層あるいは Subserosa まで進展した $\mathrm{P}_{3}$ が32例, Serosa を明らかに破っていたもの $\mathrm{P}_{4}$ が24例で， $\mathrm{P}_{4}$ では予後 が著しく悪いのは当然と云えましょう。

尚組織学的には 3 例を除き, 腺癌でありました。

以上のこと方ら演者の強調したいことはスライドの ような路あるいはそれ以前の状態で結腸癌を早期に発見 して，早期にこれを根治手術にもってゆくこと．そのた めには，まず，患者の訴えをバク然と聞くのではなくて， 
便通不整などからこれを早く見抜いて貧血や Tumor が

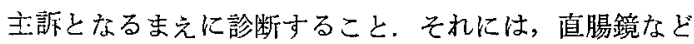
でポリープをみつけること，微小病変を診断できるスラ イド右のような大腸二重造影を普及させること．

また，手術においては，癌細胞をまき散らさぬような 操作をするよう心が付，制澏剮の選択的動注もどんどん 行ってゅくべきでわたくしたちは最近では術中病巣切除 に先立ち支配動眽幹から MMC の one shot 注入を routine 化しております。

\section{（27）大腸癌の統計的観察}

順天堂大学外科

村上 忠重, ○立川 勲, 小林 英一

消化管の癌のうちで，大腸癌は胃癌につけで頻度が高 い. 最近 5 年間の教室の統計では胃癌 $79.6 \%$ ，大腸癌 12 $\%$, 食道癌 $8.4 \%$ である. 私達は昭和 31 年より昭和 43 年 12 月まで, 結腸癌 120 症例, 直腸癌 100 症例の計 220 症 例について統計的観寗を行なったので報告する.

結腸癌の年齢分布注， 50 歳 60歳代 が 約 $70 \%$ 占め る. 直腸癌のそれは 40 歳 70歳代に比較的均等に分布す

る. 男女比は両者とも2：1で男が多い.

初発症状について，直腸癌は下血及び粘血便が55\%，

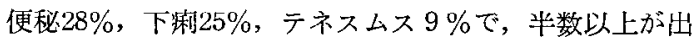
血を初発症状としている，結腸癌は，下腹痛及び腹痛が $49 \%$ ，便秘 $28.2 \%$ ，下血 $20.4 \%$ ，下㾥10\%の順で，腹痛 が約半数である。

病悩期閒は，直腸癌では $34 \%$ が，結腸癌では $25.8 \%$ が 1 年以上を経て来院しており，特に直腸癌では 3 カ月以 内に来院したものは $17 \%$ にすぎない，初診時, 初診医の 診断では，直腸癌症例の $20 \%$ が，㾌疾患として治療され ており，結腸症例では $28.3 \%$ が慢性便秘症として治璙さ れている.

直腸癌の占居部位について，腹膜ほんてん部より上 部に位置するものは $29 \%$ で，下部が71\%，従って直腸内 指㟝で，殆んどが触診し得る範囲内に発生している，直 腸漓 100例中触診可能なものは78例， $78 \%$ であり，肛門 签より $10 \mathrm{~cm}$ 以内に発生したものでは，71例中70例が触 診可能で, 触診率は $98.6 \%$ である. 即ちその約 8 割は直 腸内指診で診断が可能であり，ここに直腸内指診の重要

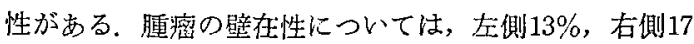
$\%$ ，前19\%，後12\%，略々全周化亘るもの39\%である.

結腸癌の占居部位は，S 状部 49 例 $40.8 \%$ ，盲腸部 24 例 $20 \%$ ，横行結腸，下行共に12例へつ $10 \%$ ，上行 11 例 9.2 \%である. 結腸癌は一般にその発生部位によって症状の 異なることが知られている。そこで結腸を左右に分け
て,腫瘤触知の有無、イレウスの発症について検討した. 右側結腸癌の場合は65.5\%と高摔に腫㾀を触知する場合 が多く，イレウス発症は左側結腸癌の場合にやや多く， 右側の $20 \%$ に対して $27.6 \%$ でる. しかし韭イレウスを 除くと，右側の $10.9 \%$ に対して $24.6 \%$ と明らかに恙異を 認め, 特に22例の急性イレウスのうち11例はS 状結腸癌 である。

手術々式について, 直腸癌症例 100例中53例は腹会陰 合併術式で, 前方切除術11例, 切除不能で人工肛門造設 のみのものは30例, Pull-through 術式その他 2 例, 非手 術 4 例である. 前方切除例の肛門輪上り腫溜までの距離 は, $7 \mathrm{~cm}, 9 \mathrm{~cm} の 2$ 例を除いて他は $10 \mathrm{~cm}$ 以上の例で あるが，この $7 \mathrm{~cm} ， 9 \mathrm{~cm} の 2$ 例は縫合不全のため再開 腹を余儀なくされたため，本術式の適応は $10 \mathrm{~cm}$ 以上と 考えている しかし癌腫の部位, 進展によっては単一な 術式にとらわれず仙骨腹腔直腸切断術式，Welch の術 式, 等, 各種術式によって根治への努力がなされなけれ ばならない，昭和38年以前と以後の 切除率, 根治切除 率，リンパ節転移率には明らかに差異が認められてい る. 前期の切除率, 根治切除率, リンパ節転移率はそれ ぞれ $66.7 \% ， 51.2 \% ， 43.3 \%$ あるが，後期のそれは， それぞれ $70.6 \% ， 58.8 \% ， 27.8 \%$ である. 更にこれを腹 膜ほんてん部より上，下に分けると，上部癌のリンパ節 転移率 $20 \%$ に比して下部癌は $41.3 \%$ と転移率惊高く, 従 って切除率, 根治切除率は, 上部癌の $74.1 \%, 63.0 \%$ に 対して下部癌は $59.5 \% ， 52.2 \%$ と著しく低率である。こ のため下部癌の場合にはその取扱い方がむづかしい，

直腸癌の遠隔成績は，他施設に比してあまり良好とは 言えないが, その 5 年生存率は $50 \%$ であり, 根治切除例 の場合でも $66.6 \%$ である、リンパ節転移のない例では $73.4 \%$ と良い，尚值接死亡は 3 例で $6.7 \%$ ，消息不明は 4 例で $8.9 \%$ である。

結腸癌の手術々式は，切除が69例，結腸半切除が 21 例, 切断 - 人工肛門が 5 例, 切除不能で吻合, 腸㿉ある いは人工肛門造設例が 24 例, 非手術 1 例である.これを 直腸癌例と同栐に前期, 後期に分けると, 切除率, 根治切 除率，リンパ節転移率注，前期の74.2\%, $45.2 \%, 58.7 \%$ に対して，後期のそれは，それぞれ $86.2 \%, 65.0 \%, 30.6$ \%で最近の根治切除率は高い，遠隔成續については， 3 年生存率 $51.2 \% ， 5$ 年生存率 $41.5 \%$, 根治切除例のそれ は $77.0 \% ， 61.5 \%$ リンパ節転移陰性例では 3 年生存率 $83.4 \% ， 5$ 年生存率 $66.5 \%$ である。尚直接死亡は 2 例, $3.2 \%$ ，消息不明は 5 例 $8.1 \%$ である。 
（28）社会保険広島市民病院外科における結腸 - 直腸癌の統計的観察

社会保険広島市民病院外科

甲斐 太郎, 畠山 哲朗, 芦 立 曔
鈴木 朗夫, 仙波 春樹, 朝 倉 晃
○伊藤 良一, 壏手 章弘, 宮本 俊彦
妹尾 紀具

われわれは昭和 27 年病院開設以来, 本年 6 月までの 17 年 8 力月閒に, 結腸癌87例, 直晹癌 118例, 合計 205例 を経験し，今回その消息調查を行ないましたので報告申 し上げます。

年度別の手術例数は，年々增加の傾向があります。

牲別は, 男 117例, 女86例で男女比は 1.4:1で, 男 にやや多く，年㱓別では，50歳代から70歳代が多く過半 数を占めています.

発生部位は, 結腸癌77例, 直腸癌 116例で直腸癌が多 く, 結腸癌では S 字状結腸が一番多く, 次に盲腸, 橫行 結腸，上行結腸の順となっており，直腸癌では殆んどが 中部，上部を占めています。

次に，主訴及び主症状を見ますと，両者の間には多く の共通症状と特徵ある相違点が見られます，即ち結腸癌 では, 腹悀, 腫瘤触知, 腹部膨満等が多く, 值腸癌で は，肛門出血及び下血，下浰・便秘，排便困難等が多く 見られます。このことは，次の病悩期間とも関係がある と考えられます。結腸直腸とも 3 力月間以内のものが多 くなっていますが, 直腸癌の場合は 6 力月から 1 年間に 及ぶものも多く見られ, 一般に他の藏器の癌に比し, 診 断確定が遅れる場合が多くみられます。

手術々式ですが，手術の方針として，相当の浸潤，転 位の見られる症例でも，可能な限り主腫瘍を切除するこ とにしています, したがって, 総数 205例中, 非切除は 僅か35例で，切除率は $84.2 \%$ と高率になっております。

結腸癌では, 切除・吻合術及び結腸半切除術を行なって おり，直腸癌の場合は多くが腹会陰式直腸切断術であり ますが，癌の発生部位及び浸潤の程度によっては Anterior Resection 又は括約筋保存直腸切除術を行なってい ます，尚腹会陰式の場合は肚門側は一次繨合しています が，入院期間も短かく，よい結果をえています。

手術後の遠隔成績は，われわれが今回行なった消息調 查の中から 5 年以上生存と認められた症例は, 昭和 39 年 6 月迄であります。総数は結腸癌 38 例, 直腸癌66例で, 計 104 例となります。消息判明数は 95 例で，調查率は $91.3 \%$ となっています.これより 5 年生存率を算出しま すと，結腸癌 $46.2 \%$, 直腸癌 $44.7 \%$ となりますが, これ
は根治手術も, 非根治手術も含屯れた, 全切除例に対す るもので，根治手術のみ趐象とすれば，さらに滈率と なると思います。

われわれの外科で経験した消化管における昰性腫煌の 総手術数は1177例ですが, 結腸值腸癌は胃癌の $80.3 \%$ に ついで，17.4\%と大きな\%を占めています。

結腸直腸癌は胃癌に比して発見が遅れがちでありま す。これは，现かしいと云う場所的な面もありますが， 肛門部出血, 下血を単なる将出血位に考え, 患者は吻論 ですが医者の方も安易に考え充分な検査をしないためだ と考えます。

われわれの外科では, 肚門部出血, 下血及び最近下痢 ・便秘がひどくなったと訴える患者には，ルチンとして 直腸鏡検查, 注腸法によるX線検查を行ない早期発見に つとめています。

以上われわれが経験した結腸直腸癌 205例について統 計的観察と 5 年生存率を調査し, 早期發見につとめてい る事を報告しました。

\section{(29) 直腸癌の統計的観察}

東邦大学第 1 外科

○大谷 忠久, 高月 正宏, 片山 责男

消化器系に発生する癌のうち, 直腸に発生する腫湟は 胃癌についで多く，その遠隔成績を綜合してみると， 5 年生存率は約 $50 \%$ 前後であると報告されて居り, その予 後は決して渾足すべきものではない．昭和35年より昭和 43 年12月迄の過去 9 年間に扱った直腸癌症例は 151例で ある。

直腸癌患者の年龄，性別について検討してみると男性 86例，女性65例で男女比は 1.3:1である，年齢別分類 では50歳台が男女共に多く，ついで60歳台の順で30歳以 下の症例は10例 $(6.6 \%)$ 見られる。 Bacon の報告で は $5.4 \%$ ，O'Brien は $2.6 \%$ と報告しているが高龄者に 多いとされている。この疾患にも20歳台で発症する恐れ のあることを示唆している.

初発症状は全症例の68\%に血便があり, 排便障書, 肛 閒部痛の訴えも多くみられる。

Bacon の症例においても，血便 $87.9 \%$ ，便通異常 $76.9 \%$ と報告され，血便，便通異常を訴えた場合は直腸 腫晹を念頭におき，その検索に努めなければならないと 思われる。

病悩期間は症状発現加手術迄の 3 力月以内のもの 46 例, $3 \sim 6$ 力月 41 例, $6 \sim 12$ 力月 18 例 1 年以上は64例で ある.6力月以上経過後手術した症例は64例 $(41.9 \%)$ の多きをかぞえ，その多くは痔核として処置又は放置さ 
れていたことは，㐓性腫愓の早期発見，早期治療の叫ば れている今日，われわれのまず考えなければならない問 題である.

しかし病悩期間と Resectability との相関々係は特に みられない. 腫瘍の占居部位は歯状線より腫瘍下緑 $3 \mathrm{~cm}$ 迄を肛門部， $3 \sim 8 \mathrm{~cm}$ 迄を膨大部， $8 \mathrm{~cm}$ 以上を骨盤 部位とすると，肛門部27例（17.9\%)，膨大部96例 (63.6 $\%)$ ，骨盤部28例 $(18.5 \%$ ) で，膨大部に発生する腫堭 が一番多くみられ，諸家の報告と一致している。

腫瘍の発生壁について検討してみると，前壁，全周壁 に発生したものが $58 \%$ と多く半数以上をしめている.

前壁に発生する腫瘍はリンパ間㭞を経由する癌細胞の 拡散が比較的容易であり周囲臟器へ浸潤しやすい傾向が あり，根治手術施行の点で不利と思われる。

われわれの151例の手術々式について検討してみると 根治手術 115 例 (76.2\%), 姑息手術 34 例 $(22.5 \%)$, 手 術不能 2 例 (1.3\%) であり，その内訳は Mile's 96例 (64.2\%), Pull-through 18例 (11.9\%), Low-anterior resection 8 例 $(5.3 \%)$, Kraske 3 例 ( $2 \%$ ), Colostomy のみは23例 $(15.2 \%)$ である.

昭和 35 年 37 年, 昭和 38 年 $~ 40$ 年, 昭和 $41 \sim 43$ 年の各 年度別の切除率は $63 \% ， 69 \% ， 84.5 \%$ であり，最近では 著し、切除率の向上がみられる. 又手術㨁接死亡例でも 149例中 7 例（ $6.6 \%)$ であるが，これを昭和 35 年〜39 年と昭和 $40 \sim 43$ 年に分けて比較すると, 前期の直接死亡 率は $6.9 \%$, 後期のそれは $3.7 \%$ ，ここにも手術成績の 向上がうかがえる。

切除標本の肉眼的所見では Borrmann III 型が $86.7 \%$ と大多数を占めている. 更に UICC の TNM 分類に 当てはめて分類すると腫湟が $1 / 2$ 周以上で可動性はない が隣切臟器に浸潤していないもの, 即ち $\mathrm{T}_{3}$ が79例 $(52.3 \%)$ と約半数以上を占めている. リンパ節転移は N.O 66例 $(43.7 \%)$ ，転移あるもの85例 $(56.3 \%)$ と半 数以上に転移を認めた. 肝転移では 4 例を数えた. 深達 度からみると筋層, 或るいは漿膜下に浸潤している $\mathrm{P}_{3}$ は79例 $(52.3 \%)$ である. 漿膜面浸潤では $\mathrm{S}_{0}$ 68例（45 $\%), \mathrm{S}_{1} 46$ 例 $(30.5 \%)$ である. 腹膜播種性転移は 19 例 $(12.6 \%)$ に認めた。

切除標本の病理学的検索では Adenocarcinoma 138例 (91.3\%), Squamous cell carcinoma 4 例 $(2.6 \%)$ Malignant melansma 4 例 ( $2.6 \%$ ) であり，これらの症 例を Duke's の分類に従って検討すると，A群 $27.2 \%$, B 群 $23.8 \%$, C 群 $49 \%$ と約半数は Duke's C 群であり進 行度の高い症例が多いことを示めし, 生存率を大きく左 右しているファクターと思われる.

根治手術を占居部位別に蚞討すると肛門部22例（74.0
$\%)$ ，膨大部73例 $(76 \%)$ ，骨盤部22例 $(84.6 \%)$ ，とな る. 又根治手術 115 例中 5 年以上経過した症例 45 例を少 数ではあるが, Duke's の分類に当てはめると，生存 16 例, 死亡 22 例。不明 7 例で 5 年生存率は Duke's A 62.5\%, Duke's B $41.6 \%$, Duke’s Cは33.3\%でめり, 平均 5 年生存率は $42 \%$ であった。

以上直腸癌 151 例について検討したが, 直腸癌の大部 分は血便あるいは，便通異常をもって発生することが多 く見られた. 又発生部位の関係无ら早期発見は比較的容 易であるはずのものが，病悩期間を見ると6力月以上を 経過している症例が約半数を占めている現況であり, 遠 隔成績の向上を図るためには早期発見即ち，Duke's A 群の状態のうちに腫瘍を発見するように細心の検索を励 行するように心掛け，早期手術例の增加を図ることが 重要で, 早期症例が増加すれば Sphincter preserving! operationの適応についても再検討され成績も向上する ものと思われる。

\section{（30）直腸. 肛門癌の発生頻度}

\author{
弘前市東北肛門病院 \\ 鳴海 裕行，見滝 伸忠 \\ 大館市花岡鉱業所病院 \\ 小原 和夫 \\ 弘前大学大内外科 \\ 杉山雄一, 西田 谁
}

近来癌の集団検診が広く行なわれつつありますが，こ れは癌の早期発見に寄与するばかりでなく，一般の人々 に澏に対する関心を高める上からも重要な役目を果しっ つあります。

しかしながら直腸癌，乳癌に対しての集団検診は割合 い関心が弱いせいか現在その報告は極めて少なく集団検 診の一つの盲点となっていむす，乳癌は体表より触知も 容易であり，直腸癌は大部分が手指の達しうる籍四の直 腸下部に発生するという事実を考えると，両者を集団検 診でチェックアウトするのは比較的容易なことといえま し上う。にもかかわらず，多数の人々を対象とした検診 が現在普及されていない最大の理由は，その部位的な特 殊性によるものと考えられます。

私共は，最近秋田県の一部で直腸肛門の集団検診を 行ないましたがその成績と，青森県弘前市鳴海直腸肛門 專阿病院における外来患者の直晹肛阳癌の頻度と,さら に昭和 36 年に弘前大学第 2 外科教室で実施した集団検診 の成績とも比較検討しので報告します。

結論としては，直腸肛門について何ら少の愁訴を有す る一群に直腸肛門癌の頻度が高くなっていること, 無症 
状のものは受診率が極めて低いこと，特に女性につくて その傾向が著しいなどのことがいえます。

昭和 41 年以降 4 年間に, 弘前市㨁腸肛門專門病院を䔻 れた新患者数は6063例で, そのうち直膓肛門癌の数は 24

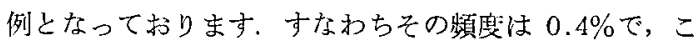
れは胃癌の集団検診よりは高い頻度となっています，た だいずれも何らかの愁訴をもったものばかりであり,0.4 \%といら数はあくまでる愁訴のある一群についての発生 頻度ということになります。24例のうち男性は 9 例, 女 性注15例で女性の数が多くなっています。また年龄層が 高くなる程その発生頻度注高く，特に50歳以上では 2.4 \%と極めて高いものとなっております。

24例いずれむ肛門輪より $10 \mathrm{~cm}$ 以内に発生したもの で，從ってすべて触診にて診断可能でした，切除率は $95.8 \%$ で，根治切除率は $77.6 \%$ となっております．この うち肛門癌が 1 例含まれて扔り，また雀卵大の Papilloma の一部に悪性化像がみられたごく早期のものが一例 ありました。

昭和36年に弘前大学第 2 外科教室が青森県下の各市町 村で実施した時のデータは，直腸癌は $0.2 \%$ となってい ます．女性の数がむしろ多いこと，また直腸ポリープが 24例発見されているのが注目されます，ただ愁訴のある ものの数が91.4\%となっており，愁訴のないものの検診 率が極めて低くなっています。

昭和 43 年, 44 年の 2 力年間にわたり秋田県花岡鈗業所 病院で実施した集団検診の成績です，1668名の全従業員 を対象とした年一回の定期健康診断に便乗して, 愁訴の 有る無しに拘わらず，半強制的に直腸指診を行ないまし た。 今のところ癌は発見されておりませんが，直腸ポリ ープが 4 例発見されました。1008名の受診者中女性は 2 名にすぎず，愁訴が特になければ女性の検診は難しいと いらことが示されております。

直腸肛門癌はその大部分が指診で診断可能であり，早 期癌発見の意味からも，この方面のより一層の発展がま たれるものであります。

質問

集団検誩で何か感じた点はありましたか。

\section{答}

直腸嵒早期発見という名目で集団検診を行なえばなか なか集まらない。

定期健影, 成人, 老人病検診の 1 部として直腸検診を 行なえば受診率があがると考えられる. 女性は勿論男性 でも差恥心が強いことが集団検診が普及しない原因と思 われます。

\section{(31) 肛門部括約機能の電気生理学的観察}

\author{
弘前大学医学部第 2 外科教室 \\ 杉沢 利雄, 鳴海 裕行, 鈴木 行三 \\ 阿保 㯪, 杉山譲, 枯崎 潤三 \\ 武内 俊, 工藤 興寿, 木村 克明 \\ 小野 慶一, 大肉 清太
}

排便は日常ごく普通にみられる現象であるにもかかわ らずそその際の直腸および肛門の機能についてはなお末 解決の点がすくなくありません：この点を解明するた め，われわれは $3 \mathrm{~kg}$ 前後の成熟家鬼 40 頭を用い，直腸 および肛門と種々刺激を加えた際の肛門括約部の筋電図 学的検索を行ないました，スライドはウサギの直腸肛門 部でヒトのそれと類似の構造をして扔ります，肛門括約 部は外部より指でつまむようにすると，輪状に筋肉の tonus の高まりが起り，容易にわかります。

この括約部の 3 時あるいは 9 時の部に， $1 / 4$ 皮下針に 封入せる直径 $50 \mu$ の日本光電製双極針電極を刺入，同し く日本光電製万能ブラウン管オシロスコープ VC- 6 型 で誘導増巾し，PC-IB 型連続撮影装置を用いて 記録し ました. この際の時定数を 0.003 とし, 撮影つィルムの.

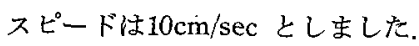

また直径 $1 \mathrm{~mm}$ のポリエチレンチューブの先端に市 販コンドームを用いて balloon を作り直腸内に捅入し内 压負荷刺激としました，その容量は $1 \mathrm{ml} \mathrm{になるように}$ 作っています。

安静時肛門括約部の放電活動をみると 2 つタイプに わかれます，すなわち(A)のごとく，全く放電活動のみ られない例, および(B)のごとく, 振ゆ50 $\mu \mathrm{V}$ 前後の単 発的な spike が, 1 秒間に $5 \sim 6$ 個の割でみられる例 です．40頭中これらの比はほぼ 1：1でありました， し かし以下に述べる種々刺激を加えた際の肛門括約部の放 電活動には雨群の差はありませんでした。

自然排便時の放電活動をみると，排便に先立ち，単発 性の spike が出現し, 時閒とともに徐々に振巾の增大, 放電間隔の短縮をみ, 排便時に山最大振巾 $500 \mu \mathrm{V}$ 前後 の burst が観察され, 排便終了とともに安静時の放電 活動にもどりました。

次に大腸内に前述の balloon を䨪入してみました. balloon $2 \mathrm{ml}$ の空気を入れ，肛門輪部より $1 \mathrm{~cm}, 3$ $\mathrm{cm}, 5 \mathrm{~cm}$ および $7 \mathrm{~cm}$ の大腸内においた際の肛門括約 部放電活動を観察するに，スライドのごとく，肛門輪よ り $1 \mathrm{~cm}$ 加 $3 \mathrm{~cm}$ の部に balloon をおいたとき放電活 動がみられ， $5 \mathrm{~cm}, 7 \mathrm{~cm}$ では全くみられませんでし た. このときの最大振巾は $200 \sim 300 \mu \mathrm{V} の$ burst で 1 
秒間に 4〜5個みられました。

さらに值晹粘膜に表面麻酶鼡キシロカインゼリーを叙 有し，balloon を捚入してみますと， spike の最大振巾 は50 100 $\mu \mathrm{V}$ と非塗布時に比し，著明な放電活動の 減 少が観察されむした，以上より直晹内容を排出しょうと する運動俚肛門輪より $1 \mathrm{~cm}$ から $3 \mathrm{~cm}$ の部が刺激され たとき発現し，これには粘膜刺载，㨁腸壁伸展刺激も関 与していると思われます。

次偪副交感神経六進棛である Bethanechol chloride, すなおち bethanechol を $0.3 \mathrm{mg} / \mathrm{kg}$ の割で筋注します と，肉眼的に排便運動が活発となり，筋電図学的にも最 大振巾 $500 \mu \mathrm{V}$ を越える，持続時間の長い burst がみら れました。 また burst の間隔も短かく，自然排便時に 比し，著しい光進状態を示しました。

また副交感神経遮断㨈である Hyosein-N-butylbro。 midum すなわち Buseopan を箭注してみましたが，肚 門括約部放電活動にはなんらの変化も与えませんでし た. さらに肛門輪より $2 \mathrm{~cm}$ の部に balloon を择入して みましたが，Buseopan 筋注前後における差異はみられ ませんでした。

次に肛門括約部を 6 時の部で完全に切断し，切断後 30 分，3日，15日と経過を追って観察しました。非刺激時 にお污る放電活動は，切断前，切断30分後，3 日後，15 日後とも変らず, 前述の安静時放電活動と差はありませ んでした，balloon を挿入してみますと，切断值後では balloon はすぐ肛閒外に排出され，筋電図上でも，非切 断時にみられた burst と注全く異なった振巾 $200 \mu \mathrm{V}$ 前 後の単発的な spike の出現をみました. Bethanecholを 筋注し，排便を行なわせてみますと，筋電図上，非切断 時より放電活動は低下しているにもかかわらず肉眼的に は休みない排便がみられ，便失禁を思わせる状態でし た。しかし 3 日後, 15 日後と経過を追って，直腸内 balloon 挿入時および Bethanechol 筋注後排便時肛閒 括約部の状態を観察するに，切断された括約部の連絡は 不十分でありながり，肉眼的に便失禁状態はみられませ んでした，15日後の筋電図では，切断直後にみられた単 発性 spike ではなく，非切断時と似た burst の形成が 観察されました，以上の所見より肛門括約部は排便調節 機構とくに直腸内賞便貯留の面で重要な役割を演じてい ると考えられます。

今後, 大腸と肛門括約部との同時記録による筋電図学 的観察, 直腸内圧と肛門括約部筋電図上の相互関係等に ついて，さらに研究を進めていきたいと思います。

討論束大石川外科 土屋 周二

ヒトに打ける外肛門括約筋筋電図をみると排便初期に おいては放電活動が増強するが排出されている時は抑制
が著明である，御発表はウサギにおける結果であるので ヒト上動物に打ける差であるかも知机ない．

骨盤内膿谤で括約筋の弛緩していた症例で法著明疗放 電活動の低下がみられた。

討論弘前大第 2 外科 杉 沢 利 雄

排便時に最大振巾がみられるようですが， spike が排 便より幾分先行する様です，

質問 小平 正

外括約筋筋電図の波型だと思われましたが括約機構と して内外両括約筋の協同ということも考えられますので 両者の機能を筋電四学的に解明出来ないでしょうか.

答 杉 沢 利 雄

人の場合法内括約筋と外括約筋とにわ计て電極を入れ ていますがウサギでは肛門括約部に 1 本だけ電極を入 れ，内外括約筋，赤筋，白筋については考慮していませ h.

\section{（32）肛門管の組織化学的研究 (第 2 報)}

\section{土岐市立䭾知病院 岐皁大学第 1 外科}

檜 堤 潜

昨年に引き続き人体の肛門腺を，主として組織化学的 に検索した.

今回は胎児 7 例, 新生児 2 例, 成人 7 例を增し, 計33 例につき肛門腺の構造拉よびその分泌機転を観察した。

材料のとりかたと検察方法とは非年と同様であるが， 成人 2 例にてカーボワックス封入のもとに脂肪染色を行 なった。な扮切片の染色はニンヒドリンによる蛋白染 色, マッソン染色ゴメリー変法, トルイジンブルー染色 法, パス・アルシャンブルー重染色法, などを追加し た.

肛門腺は，全例にて，導管とみなされる部分を持って おり，内肛門括約筋を貫ぬく導管は内括約筋内では枝分 れしない，大部分の症例では，その末端部に数個の肛門 腺の腺房がついており，内括約管を貫ぬく肛門腺は分岐 管状単一腺であると考えられる。

肛門腺の上皮細胞注多層であり，中に多くの分泌物が 認められるものでは，層が割合にうすい. 肛門管をその 長軸に対し横に切った標本で見ると，ある肚門腺は円形 で分泌物を多量に含み，壁はうすくなっており，また他 の一つは棈円形で, 内腔に分泌物が認められなかった。

肚門腺およびその導管は分跳物を一眭的に貯える力を もっているようで，分泌物のない時注筋に圧迫されてい るのであろう。

胎児, 新生児の肛門腺は成人のそれに比べてはなはだ 
大きい，肚門陰窩は逆に成人の方がよく発達し，入り込 み，枝分れむはるかに媣い. 従って肛門腺は退行性の腺と 考えられるが，分泌機能は老人例でもなお認められた。

$こ 0$ 分泌機能については胎児 $(4 \sim 6$ 力月 $)$ と新生児 〜成人のものとはかなりその様相が異なる. 胎長 $15 \mathrm{~cm} の$ 4 力月の胎児で既に腺房形成と管腔形成が認められ，中 に分泌物が認められる。 この分泌物はアルシャンブルー に青く染まる部分むあり，そしてパス・アルシャンブル 一重染色でもやはり青く染まる。 またムチカルミン染色 で桃色化，アザン染色で青く，マッソン染色で緑色に， パス染色で赤紫色にそれぞれ染まる部分もある。しか し，腺腔内には核の遊離は見られない．

一方，新生児，成人では腺㧍よび導管内に多数の核が 遊離していた。

成人例では肛門腺内腔側の細胞が円柱状になり，核は 基底部に片より，その一部は空胞を形成する。 また一部 の細胞は核が核染色に濃染し, 原形質は粘液染色に陽性 である、この核の濃染するものでは，細胞の輸敦が崩れ かけ, 腺の内腔側へ脱落しかけているものが見られる. 腺腔内に脱落した細胞から遊離した核は大小色々あり, 次第に小さくなるものと思われる。

成人 4 例で, 肛阴腺導管内の分泌物壮，ホルマリン固 定，カルノアー液固定のいずれでも，(1)粘液染色に染ま る部分と，(B㤥染色に似た染まり方をする部分との 2 領 域に分れた。これをマッソン染色で見ると前者(Aは緑色 に，(B後者は赫く，アザン染色で(A)は青く，(B)は赤く， アルシャンブルー染色で(®)は青く(B)は橙色に，ムチカル ミン染色で(A)は桃色に，(B)橙色に染まる，パス染色で は(A)(B)両者の間に慰はなく赫紫色に，トルノイジンブル 一染色とニンヒドリンによる蛋白染色では(A)(B雨者とも 染まらない。

この 2 通りに染まる物質は，肛門腺に近い処の導管内

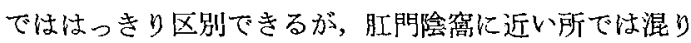
合っていた.

それ以外の症例では, 粘液のみ，または粘液の中に核 が見られるだけであった。この粘液は昨年報告した如く 酸性粘液で, パス・アルシャンブルー重染色では青く， マッソン染色では緑色に染まる。 しかしトルイジンブル ーでは染まらない。

成人 2 例のカーボワックス封入標本でズダンIII染色を 行なった. 78歳男のその 1 例では肛門腺分泌物の中にズ ダン而に染まる物質と染まらない所があるのを認めた， ズダンIII染まる部分では，その部分の上皮細胞の一部 も橙色に染まっていた。すなわち肛門腺分泌物は脂肪を 含むことがある、カーボワックス封入標本は切りにく く，連続性が不確実なため，乙の脂肪染色陽性の部分は
腺か導管かはっきりしないが，位置，形からは導管と考 えられる。 また 23 歳男の 1 例では内括約筋内に腺および 導管らしいものが見られここれはズダンIII染色で全く陰 性であった。

以上のことから肛門腺柱腺の一部が脱落してホロクリ ン腺の如き分泌作用をいとなみ，分泌物は肚門腺および 導管の中に一時的にたくわえられるものと考えられる。

導管の中に粘液が沢山見られる切片で，導管壁が扁平 になっているものが見られ，その近くでは上皮細胞が円 柱状のもの涼形質が粘液染色偒性であり，立方状加 ら扁平なものは陰性であった。

前回の報告で，導管の壁仙注分泌作用が全く見られな マと述ベたが，導管にもメロクリン腺様の分泌能力があ り，分泌後は㾫平になるのではないかと思う。

なお前回の報告に際し，私は Hill がこの導管内にて 粘液染色㳊染まら好分泌物を認めたといったが，彼法力 ルボールフクシンに染まると記載していた.

ここで誤りを訂正する。

肛門腺分泌物は，粼液と多糖体の混合物で，そ㣗に核 の分解物がまじっている，核は崩解して蛋白質または核 酸になるのではなく, 核酸証明のとき, 塩酸で加水分解 し，その糖を証明するのであるが，上記のßはすでに分 解されて糖質になっていたものと考える。というのは $\mathrm{HCl}$ による加水分解をしなくてもすでにパス染色で陽 性になっていたからである。また蛋白質でないこと法， ニンヒドリシンによる蛋白染色で陰性であったことによ り想像される。

Burke (1951) や Kratzer. (1947) は粘液染色に染ま らない所見を報告したのはこの理由によるものと思う。

\section{（33）肛門科領域における臨床検査の意義}

横浜市松島病院

松島 善視，鈴木 信夫，衣笠 昭

肛門科疾患患者の数注近年次第江増加し, 手術術式, および術後処置も的確な方法が行なわれつつある。しか し, 従来より肛門部の手術は, 安易に行なわれすぎてい た傾向があり，手術侵襲が全身に及ぼす影響を考虑に入 れなかった為, 不慮の事故が発生したということも時々 耳にする。われわれは肛門手術に際しては minor surgery であるからこそ手術に關する偶発事故は絶対に避 けるベきであり，事故を事前に察知してその対策を立て るべきであると考える、この対策の一環として，われわ れは数年前より術前術後の臨床検伹を行ない，侵熟を加 える前に潜在している疾患を把握して好結果を举げてい るので，その一端を報告する. 
1. 問診 : 大腸, 肛門に関する問診を行なうことは当 然であるが, その他, 心, 肝、!腎, 肺!消化器系に関す る疾患の有無, 高血生, 代謝疾患などの病名を挙げ, 患 者を誘導して叫く，その他，アレルギー性疾患，重要臓 器の外傷も参考となることが多い，また，女性に対して は媂人科疾患, 老人男子においては前立腺疾患も重要な 項目である。

2. 打聴診 : 胸部，腹部の打聴診であるが，これによ り心, 肺, 肝疾患, 消化器系疾患の有無を確認する。異 常を認めた場合レントゲン検查.心電図検査を行なう が，同時に血压測定も重要な検查の一つである。もし高 血压が認められたならば，検尿，検血を慎重に行なう一 方, 眼底検査, 血中コレステロール， $\beta$ リポ蛋白の定量 を行なう。

3. 血液検查：血液検查は, 赤血球, 白血球, 血色素 数,ヘマトクリット, 出血時闒, 凝固時間をルーチンと して行ない，次に述べる尿検查で腎障害の疑いのあるも のには尿素窒素を, 衰弱の著しいものに対しては血清蛋 白を測定する。 またへマトクリット測定時に血消の色調 を見，黄疽の有無を調べている。

4. 尿検查 : 検尿は糖, 蛋白, ウロビリノーゲンの定 性を中心として行なうが，この中ウロビリノーゲン陽性 が必ずしも肝機能障害をあらわすものではないので，症 例によってはビリルビン定性も同時に行なっている，蛋 白陽性のものについては沈渣を調べ，腎障害があるの か，尿路感染症なのか，京たは泌尿器系藏器の出血によ る蛋白尿であるのかを検討する．糖陽性の場合は血糖検 查を行ならが, 坂口食を投与し, 投与前, 投与後 1 時間 および 2 時間値を測定している.

以上のような検查の最初の段階は, 特別な検查施設が なくとも充分外来で行なえるが，特に最近いするるイン スタント検查試真が普及し，簡単かつ正確に結果が出る ようになった，表中点線で团った部分は，われわれは Ames 社の検查試薬を使用しているが，この試薬と血液 検查用具一式あれば，比較的頻度の高い疾患は捕えるこ とができると考える。

5. 薬骩過敏性検查：当院では手術の大半は局所麻醉 で行なうので，手術前に局所麻酔剤の皮内反応を行なっ ている、しかし，皮内反応は信頼度が低いので，疑わし いもの，過去に過敏性反応を経験しているものについて は鼻粘膜反応を行ない全身状態を観察した後手術を行な っている，このようにして得た結果を手術の可否に結び つけるのであるが，われわれはスライド3のような結果 が出た場合は一応手術を中止し，更仁詳細な検査を行な った上発見した疾患の治療を行なった後手術を行なって いる.
次に検查によって手術中止または不可と決定した臨床 症例を 2 例举げてみると，40歳男子，痔核第 3 度で脱水 を伴なっており，手術前処置を行なわなければ重大な合 併症を起したであろうと思われたものである.16歳男子 で, 他医より肛門膿場として当院に紹介された症例は, 試験切除片の病理組織学的検查でほ Lymphosarkom で あったものである。

肛門科領域に打ける，いわゆる緊急手術というものは 極めて少なく,わずかに肛門膿瘍の切開や, 痔核に対する 鎮痛の目的に血栓除去を行なうくらいのもので, 状況に よっては手術延期も可能なものが殆んどである，従って 手術前に充分臨床検查を行ない，術後合併症の予防に務 めることが必要と考える. 当院で昭和 43 年度に行なった 検血の結果, 貿血のあるものは全患者の $5.5 \%$, 検尿の 結果蛋白陽性のもの $3.2 \%$ ，糖陽性のもの $2.5 \%$ で，比 率としては少数であるが，この少ない異常患者中から重 大な結果が生れるであるうことを考えると, や注り臨床 検查の意義を認めないわけにはいかない．

術前検查を行なわなかった為発生した合併症は，われ われが経験したものでは白血病の増悪, 肝炎の増悪, 急 性腎不全，心不全，局麻㓮アレルギーによる肺水腫など であって，いずれも臨床検查を術前に行なっていならば 避け得られたであるうと思われるすのである。

近年医療過誤による補償問題が多発している折から， 如何にして安全に手術を行ない，患者に余分な負坦をか けないようにするかを考えるとともに，医療過誤にから む訴訟問題に対しても充分に対処できる診療体制をもっ ていることが必要と考えるので，あえて常識的とも思わ れるこの問題をとりあげ，ご批判をこう次第である。

\section{（34）痔疾に対する BM-S 坐薬，及び BM-O 軟亳，使用の経験}

$$
\begin{aligned}
& \text { 京都市第 } 2 \text { 大羽病院 } \\
& \text { 三瀬 真一, 増田 強三 } \\
& \text { 增田医院 } \\
& \text { 増田 久勲 }
\end{aligned}
$$

古来, 痔疾に対する坐薬及び軟骨の種類は夥しい数に のぼり，、ずれも有效と云う報告があるにもかかわら ず，現在も新しい薬羭が製造されているということは， いずれの薬殽も $100 \%$ の有効率をあげていないからであ る. 局所に貼布もしくは雨入して効果のある将疾は比較 的軽度の㾌核, 侍裂, 肛門周囲炎等であるが, 肛門周囲 炎の場合は抗生物質の全身投与も必要であ万5，歩いて も脱出するような内桪核や，長期閒排膿をつゔけている 㾌㿉が坐薬や軟鄨の塗布位で治癒するとは考えられな 
$\checkmark$.

われわれが坐莯や軟亮を局所に使用する場合は，大き く分けて二つある。一つは軽度の盲将核, 痔裂に対して 非観血的, 保存的に治療する場合で, 第二は滈度の浆㮎 や侍瘦の根治術後の創面に対して使用する場合である.

従来の軟骨㨈では, 矹酸軟亭やピチロールパスタ, オ ーレオマイシン軟管, マイシリン軟商, ポステリザン軟 衰, ルブリテックス軟育, ボラギノール軟嗉, その他で 坐薬ではポステリザン坐薬, ルブリテックス坐薬, ボラ ギノール坐薬, 他多数を用いてみたが, 何れる軽度のも のには可成り効果があった.

創面に使用した場合は，患者によって創面の肉芽の形 成が，或る薬剤では悪く，或る薬剤ではよかったりし て，一定しない，また創面の治療経過中，初期には非常 によいように思っても 2 週間位経過すると肉芽が弛緩し て来たりする場合もある。したがって一種類の薬椷を大 きな創面が完全に治癒するまで全期間用い得ないことが 多い.

このことが，また新しい製凨の必要性を生むものと思 う. 最近坐薬 (BM-S 坐薬と略称) および軟塾 (BM-O 軟瓷と略称）を使用する機会を得たので，その成績を報 告する.

使用例及び効果：使用例は，侍核，将裂等で軟育及び 坐薬のみを使用し，手術的侵襲を加えなかった症例22 例, 手術後使用した症例 26 例, 痔蛽の手術後使用したも のが39例で総計87例である.

BM-O 軟膏の使用法は， $8 \mathrm{~cm} \times 6 \mathrm{~cm}$ 大の ガーゼに この軟育を約 $2 \mathrm{~g}$ 叙布しここれを肚門内に挿入，もしく は創面に貼布した。坐薬は1日2回1ケあて雨入した。

効果判定は手術的侵襲を加えなかった症例では，主観 的なものであるが，可及的主観を排する目的で主症状の 二つ以上が 1 週間以内に消失したをのを，著效+とし t.

また, 症状が本郕を 3 週間以上使用し，乙かも他㓮の 併用によって軽快したもの等を有効十とし，また症状は 軽快しても一部の症状の残ったものをさとした．長期間 使用してを效果なく，手術を行なった例を無効とした。

軽度の盲痔核，もしくは痔核兼痔裂の症例 22 例の成績 は著效，15例68\%，有効 4 例 $18.2 \%$, や队有効 2 例 9.1 $\%$ ，無効 1 例であった。

また，疛核，ポリープ等の切除後に使用した症例26例 中著効は 17 例 $65.4 \%$ ，有效 1 例やや有效 7 例 $26.9 \%$, 無 効 1 例であった.

次に痔璂根治術後の創面に BM-O 軟鹌をガーゼに貼 布し使用した成績㵔著効 23 例 $59 \%$ ，有効 5 例 $12.8 \%$ ，や や有効 5 例 $12.8 \%$ ，無効 6 例 $15.4 \%$ であった。この際，
創面に軟亮を叙布したガーゼを貼布して著効としたのは 一部黄白色の Belag のあったものが，3 日以内にとれ て，きれいに肉芽組織となった場合で，有効と注この期 閒が脣びき，他の坐薬や蛋白同化ホルモン等の内服もし く注注射を必要とした場合で，やや有効は多少肉芽がき れいになっても遂に他剤に変更した場合で, 全く肉芽組 織の改善む認めず，数日に他剤に変更した場合を無効と したのである。

以上の如く, 本版は軽度の盲将核, 疛裂には比較的有 效例が多く, 将瘦手䛔後の創面に対しても相当有効であ ることは，他剛と比へ接色のないものでする。

このよらに痔疾の症例を選んで，使用方九壮，十分効 果を期待できる薬㶡であるといえる。

\section{（35）教室における坐薬の使用経験}

名古屋市立大学医学部第 2 外科

○新田 隆, 竹内 隆, 服部 節朗 本多 英邦, 池 内 彦

痔疾患は肛門疾患のうち外科医がしばしば遭遇する疾 患であり，わが国では排便様式，生活環境より特に多数 接する機会がある、

今日侍疾患治療として先ず坐薬, 軟埛主主とする内科 的燎法, 続いて内服, 舌下錠を用いる保在的療法, 注射 法, 結紮法, 最後に切除を目的とする根治療法である.

現在, われわれの教室では脱出嵌頓㾌核, 難治性痔

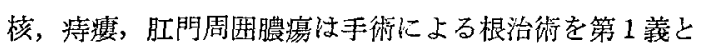
するが, 軽症, 中等症痔疾患並びに切除後, 結㮃脱落後 の創面治瘾促進に坐薬, 軟率を主体とする治療を行なっ ている. 今回, 名古屋市立大学第 2 外科, 並び传室関 連病院を訪ずれた肛門疾患患者のうち 133例をほぼ無選 択 (的)に選び, 各種坐薬の5ち $\mathrm{A}$ : 配合製剤, B : 動物静脈壁 エキス剂及び C : 抗炎抗菌剤を使用し, 出 血, 疼痛, 瘦痒感, 分泌物排出, 浮腫腫脹, 脱出, 圧 痛, 異和感, 結節縮小などについて検討を加え若干の知 見を得たので報告する.

投与法は各々の症例につき坐蒋 1 本づつを朝夕及び就 寝前に版門内に挿入，A群注 10 日間の速続投与，他江 2 週間の連続投与後勃果を判定し，その他処置としては緩 下郕投与, 湿布程度にとどめた。

対象症例注内峙核 $\mathrm{A}$ 群, 60 例中 39 例 $65 \%, \mathrm{~B}$ 群仗38例 中19例50\%，C群は35例中24例，68.6\%で，何れのグル 一プも内庠核が最も多く, 他の血栓性外痔核, 痔裂, 脱 肛の順であり, A群のみについては肛門瘦㾕症, 肚門周 因炎が含委れている。

効果判定については, 出血, 疼痛, 瘦凊感分泌物排 
出, 腫脤, 脱出, 異和感, 区痛, 結節縮小の 9 つの症状 のうち4 つ以上に効果ありと認められたものを有効，1 ３症状に効果ありと認められたものをやや有効, 何ら の改善のないものを無勃とした.

また各々の症状については，強度のものを(州)，中等 度のものを(H)とし, 柽度のものを(十), 症状のないも のを(一)とし, その症状の移動即ち (十)2つ以上移動す るものを有効, (+) 1 つのみ移動するものをやや有効, 全く移動のないものを無勃とした.

先づ総合効果についてはA群にては肛門瘦嫊症, 肛門 周囲炎を除くと有效例については C. A. B の順となり, 無効例にっいてはC群が最も少く, A B 群は大差ない。 次にこれを疾患別に検討するとスライドの如くであり， A群では内痔核に扔いて重症例が多かった為か, 無効例 が23.1\%を占めやや多いが，B群では認めていない，し かし $\mathrm{A}$ 群は C 群の有效 $25 \%$ に続いて 27 例 $17.9 \%$ 占めて いる.

血栓性外洔核, 脱肛, 㾌裂法何れも症例数少く, 効果 も血栓性痔核で洼軽度に認められるが, 脱肛, 痔裂では 殆んどなく，他の処置を必要とする疾患群である。

各症状別にみると，出血はA群では 57例中 28 例 49.2 $\%$, B群では38例中28例73.6\%，C群では35例中16例 45.5\%にあり, B群で最も多い, 效果柱有効, やや有効 を含めると $\mathrm{A}, \mathrm{C}$ 群は大差ないが， B 群でやや劣って いる. 疼痛は A，B，C 3 群何れもほぼ同頻度に認めら れており，B，C 群では有効例が $80 \%$ 以上を占めるが $\mathrm{A}$ 群は $50 \%$ 弱でやや劣る. 瘦痒感はC (群) にて有效が認 められた。

分泌物排出は A，C両群のみについてみたが，C群 にてやや有効である. 腫脹浮腫はC 群に最も多く又急性 型のものがやや多く 9 例 $69.2 \%$ に有钩であるが，A群で は頻度もやや少く慢性化を思わせる症例が高い為か, そ れほどの勃果はなかった. 脱出はA 群にて頻度が大であ り, 程度が強い為か, 単独療法では効果が少い. 圧痛は 何れも比較的涫度頻度に認められるが, 効果は比較的少 、. 異和感は A，C 雨群何れも活ぼ同頻度に認められ る. C群にてやや有効の様に思われる.

発病後の時期と刹果との関倸注発病後 1 日〜29日，30 日〜 1 年, 1 年以上の 3 群に大別すると， 3 群何れも発 病後経過の短いものは有効であり, 29日以内の䇥例頻度 法，A群，60例中 21 例， $35 \% ， \mathrm{~B}$ 群38例中 18 例， 47.2 $\%$ ，C群35例中 20 例 $57.1 \%$ であり，C群では腫脹浮腫を 伴った急性型が多いのに比し，A群では難治性のものが 多く效果もある程度劣ったのではないかと思われる.

副作用については，何れもわずかの症例に坐薬融解物 の肛門からの漏出, 不快感,しみる様なピリピリする感じ
を経験しているが使用に不便を感ずることはなかった。

A， B，C 3 坐薬投与群について臨床效果を中心に検 討を加えたが，A群は比較的陳旧性のものが多く含ま れ, 使用期間も10日間であるが， B，C 群は病悩期間が 1ケ月以内のものが約半数を占め使用期間も14日間であ るため訤果判定の比較に多少の問題があり, 季節的, 年 令的配虑, 使用時期が一定していないため適確なる効果 判定は容易ではなかったが，各種薬郕の勃果を総括する と, $\mathrm{A}$ 群では出血, 瘙㾕感, 分泌物排泄, 疼痛に, $\mathrm{B}$ 群 では出血, 疼痛, 浮腫, 不快感にC 群では出血, 疼痛, 瘦 棒感, 分泌排泄, 腫脹に対し有効である。しかし比較的 症状の軽いものでは C群が最も効果的であり, ハイド ロコーチ・゙ンの抗炎・抗アレルギー作用, フラジオマイ シンの抗菌作用の影響と考えられ，疼痛，浮腫に対して は， B，C 両群がより有効である。これはB群では豚の 静脈丵より抽出した Polypeptide の血流改善, 結合織 強化作用, C群では副腎皮質ホルモン塩酸ジブカインの 相加, 相乗效果を示したためより有効であったと考えら れる.併し，A群の副作用を全然考慮せず，手軽住安全 に使用できる点も注目すべきところである. 以上夫々成 分の異なった坐薬投与 3 群につき我々の経験を報告致し ました。

（36）将核の薬物療法における 効果判定基準に ついて

$$
\begin{gathered}
\text { 日本大学石山外科 } \\
\text { 坂 部 孝 } \\
\text { 社会保険中央総合病院肛門病七ンター } \\
\text { 隅 越 幸 男 } \\
\text { 医療法人惠仁会松島病院 } \\
\text { 松 島 善 視 } \\
\text { 東邦大学小平外科 }
\end{gathered}
$$

㶯田謙藏

薬物療法の臨床刹果判定注使用薬郕㧍よび疾患の如何 を問わず常に困難なもので，特に痔核のように自然軽快 ないし自然治療をおこしやすい疾患では, 薬剛の真の勃 果を判定することは一鶕難しいことである.

われわれ情数年前に痔疾患に対する坐薬療法の効果を 各症状の程度によってそれぞれ+，十，士，一の4段階 に分けて判定する方法を検討し，その成績は順天堂大学 外科の小出来先生が第19回本会総会で報告した.

今回は内服薬 Fragivix 錠の臨床治駼の依頼があった のを機会に，点数による効果判定を試みたので報告す る.

臨床䎟果を判定する基準として内痔核の臨床症状のう 
ち, 疼痛, 出血, 脱出, 痒感掞よび分泡物の 5 つを举 げ,このらち最も頻度が高く内持核の主症状である䄂痛 と出血に対しては, 症状の程度によって 5 点, 3 点, 1 点と点数を与え, 脱出には 2 点あるいは 1 点, 痒感と分 泌物には，これらがある場合は1点とした。このように 主症状と随伴症状とによって点数に差をつけ,且つ,各々 の症状に打いてもその程度によって点数に差をつけた。

次に病型の判定基準ともいえる, 既住歴㧍よび罹病期 間に対しても点数を与えるが，これらは效果判定の時は 0となる。

効果の判定方法法, 治療開始前に症状別に之れぞ㚊 当する点をつけ, 治療開始後効果を判定する時にも, 疼 痛, 出血, 脱出に対しては治療前の点数基淮に準じて点 数をつける.

例えば，治療前にポタポタたれる程度の出血，すなわ ち 3 点であったものが增覀してほとばしるような出血と なった場合は 5 点, 紙につく程度になれば 1 点といらこ とになる，また，痒感と分泌物に対しても增覀すれば 2 点, 不変ならば 1 点となる.

効果の判定時期を一応 1 週間後と 2 週間後とし, 点数 の処理は治療前と判定時期のそれぞれの合計点から減点 率を算出して臨休効果を判定する。今回は減点率85以上 を著効，70〜84を有効，69以下を無効とした。

症例を例に挙げると，43才男子，治療前の答痛は排便 時のみで 1 点, 出血はポタポ夕おちる程度で 3 点, 時に 脱出がみられるので 1 点， 1 週間前から症状が現れたの で䍜病期間は 1 点, 既往歴があるので 1 点となり，治療 前の合計点数は 7 点である. Fragivix 錠を 1 日 6 錠づ つ 1 週間内服後は脱出を除く他の症状は消失し, 合計点 は1点となって減点率は85.7で著効と判定された。

次の症例は 30 才男子, 体動時疼痛, 排便時にポタポタ おちる出血と脱出があるが，既往歷はなく，罹病期間も 3 日以内で治療前の 合計点数は 7 点である. Fragivix 内服 1 週後にも疼痛と脱出は軽快せず不変で, 出血は紙 にっく程度となり效果判定時期の合計点数は 5 点, 減点 率は28.6となり無効と判定された。

われわれはこの方法を用いて痔核の内服薬 Fragivix 錠の double blind test を行った成績を検討した.

症例は全例内痔核で63例, Test の方法は 1 日 6 錠つ つ 週閒分を包装したものを投薬し，他の治療法の併用 は行なわなかった。判定時期を 1 週間後の 1 回のみと し, 全症例の効果判定を行った後に包装番号により Fragivix 錠であったが, Placebo 錠であったかを照合 した. Fragivix 錠使用例は29例, Placebo 錠使用は34 例で，それぞれの減点率の平均は Fragivix 群は67.7, Placebo 群は63.8となったが, 推計学的には有意な差と
は管えない，しかし，Fragivix 群には全症状の消失し た減点 100 の症例が 5 例あり著敬例が多いのに反し， Placebo 群では減点率 100 の症例はなく著效例も少い.

既往歴の有無によって両群の成績をみると，既往歷を 有する症例では Fragivix 群がやや高い減点率を示す が，有意な差とは言えない，罹病期間では，3 日以内の 極く短い症例と10日以上の長い症例とに分けてみると， 罹病期間の短い症例に Fragivix の隇点率が高く, $5 \%$ の危険率で有意差があった。

個々の症状別に効果判定寸ると，疼痛に対しては両 群にほとんど差がないが，出血に対しては Fragivix 群 の方が減点率がやや高い.

以上の成績から内将核は Placebo 錠でもかなりよく 治るということが言えよう。これは投薬時に与えた内痔 核治療上の一般的な指示によって自然に軽快ないし治瘺 する傾向の強、内将核本来の性質によるもので, 莧物療 法の効果判定の困難さを物語るむのであるう．

なおここに報告した効果判定基準の根本となる各項 目の点数には確固たる根拠があるわけではないが，ある 程度臨床経過を客観的に具現しているものと考えてい る.

このような方法によれば 2 種類以上の薬俨の効果の比 較も可能となり，同時に症状別の勃果も知り得ておの扔 のの薬㶡の特徴も現れてくることもあると言えよう，

追試と批判を扔願いする次第である。

\section{（37）痔核切除に対する結紮切除と 粘膜下切除} について

名古屋市瑞穂区野垣病院

升森 茂樹, 野垣 茂吉, 尾関 武郎

痔核手術々式として古くより色々の術式が行加各人 各樣の考えのもとに，一定した術式を見ない，最近にい たり Free Drainage を主派とする Milligan-Morgan の 結紮切除法がとりあげられ，各方面で行なわれるように なった.

われわれの所では数年前より結㷊切除法を行っている

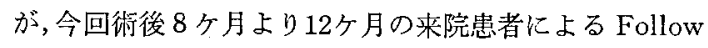
up とアンケートにより，その術後合併症について検討 を行ったので，ここに報告する.

Milligan 術式アンケート100例中来院せるもの26例, 返信のみ22例の48例に Follow up が出来えた. 先ゔア ンケート返信より痔核度数と年令では, 20 加ら 30 代に 13 例と半数以上をしめ，度数からも男女合せて17例と 2 度 痔核であり，保険診療による一つの傾向と思われた、䍜 病期間についてはさしたる傾向はないと思われるが，1 
年末満 8 例， 10 年以上 6 例と多少多いともみられる.

アンケートにより何らかの愁訴を示めすものは，22例 中11例 $(50 \%)$ であり, 各症例の訴えより判断すると広 義の肛門择㾕症, 裂肛, 肛門機能異常を予想しえた。 また排便感については，良好 9 例 $(40.9 \%)$, 不变10例 $(45.5 \%)$ ，不良 3 例 $(13.6 \%)$ であった.

次に Milligan 施行例で直接来院せるもの 26 例であ りアアンケートにそい問診を行い，術後状態につき触診 及び肛門鏡下の視診により十分な観察を行った。

痔核度数と年令についてはアンケートと同じ侍核 2 度 のもの 23 例と $88.5 \%$ \%める.

䍜病期間は 1 年末満 27 例中 9 例, 3 年末満 7 例, 6 年 末満 4 例, 10 年末満 4 例, 10 年以上を示すものは 2 例の みであった。

来院時所見とその愁訴を見ると，異常所見を示すもの 26 例中 13 例の $50 \%$ ，何らかの愁訴のあるもの 6 例 $23.1 \%$ を示したが，他は何ら所見及び愁訴を持っものはなかっ た.

異常所見は手術浸襲の加光られていない部位の残存侍 核 2 例, Wunde Heilung 不良の為の人工裂創 5 例, 手 術時には見られなかった軽度の肥厚乳頭 2 例 Skin Tag 3 例, 痔核切除の剝離不十分によると思へるびらん 1 例 の計13例であり，その中での人工裂創 5 例は26例中 19.3 \%であり，十分注意すべきものと思われる. また残存侍 核, 肥厚乳頭の存在についても同様である.

来院時の愁訴あるもの 6 例で来院患者の $23 \%$ を示した が, その詳細法出 3 例, 搔㾕感 2 例, 排便異常 1 例, 細い感で 1 例であった. 度数の上では全例が 2 度のもの である.

この様に愁訴の上では, 肛門狭窄, 掻痒症などが疑え たが，視診，触診上ではこれらを見出せなかった，排便 感にっレては表の如くである.

当院に於いては肛門疾患が主であり，年間外来は6000 余, 入院手術例に於いてを 2800 余例の多きを数える。 そ の関係上種々の形の痔核に遭遇する。一般に結禁切除で は肛門機能維持のため 3 ケ所の切除にとどめるべきと云 われているが，明らかに異常動脈分岐下と思われる将核 に対し, 肛門狭窄回避のため, また他疾患の合併例に Milligan に加え Parks 法を追加し，4ケ所切除による 肚門浸襲の軽減とその追せきへの與味で, Milligan,

Parks 併用による 4 ケ新切除を行った.

来院患者15例の Follow up よりみると， 2 度痔核 9 例中 1 例に肉芽創, 排便感は 9 例中 7 例良好, 不変 2 例 で肛門に対する愁訴をっものは1例もなかった， 3 度 の痔核例では, 異常所見は症例 1 の残存痔核,ただし愁 訴むなく排便感も良好である。症例 3 , 出血, 疼痛を有
し，明らかに人工裂創を形成していたが，排便感は良好 である. 症例 5 , 肽門潰瘍よりの皮下痔瘦術後の軽度の 肉芽創を有していたが，愁訴もなく，排便感も良好であ った，症例 6 では残存㾌核を認めたが，訴えは見られな 加た。

Milligan, Parks 併用15例中, 残存凊核 2 例 (13.3 $\%$, 人工裂創 1 例 $(6.7 \%)$, 肉芽創 2 例 $(13.3 \%)$ で あり, 訴えあるもの1例のみ，排便感についても，不変 2 例を除き，13例が良好であった．このことから，4 所切除にあっても十分肛門機構をそこなわず，手術浸襲 可能の籁囲と考えられる，以後症例をふやし検討される ベきものと思われる.

一方 Parks 氏法27例に Follow up を行った。将核 度数と年令については， 2 度の痔核 22 例， 3 度の痔核 5 例であり，20から30代の18例とほぼ67\%をしめている.

䍜病期間は 1 年末満 12 例と約 $50 \%$ をしめ, 比較的, 青 壮年の手術例が多いと思われる。

これら27例の Parks 施行例の 来院時所見と愁訴を見 ると，所見あるもの15例 $(55.5 \%)$ ，愁訴あるもの 1 例の み $(3.7 \%)$ であった.

異常所見を示めす 15 症例の5ち，1つ以上の所見をも つものは 4 症例であった. 残存侍核 5 例, 肥厚乳頭 6 例 肛門ポリープ1例の計12例は Parks 施行例の $44 \%$ であ り，その遠隔の成り行きに対し注目すべきものと思う。

をた裂創 5 例 $31 \%$ ，全 27 症例の $19 \%$ を占めることは一 䒴すべきものである。

排便感では不良例はなく，27例中良好 22 例 $81.3 \%$, 不 変 5 例 $18.7 \%$ であった。

以上，本院に於いて行った 3 術式での 8 ケから12ケ 月の Follow up により, Milligan, Parks 併用の 4 ケ 所切除でも排便機能が十分保たれ，まず手術浸襲可能の 範囲と思われた。 また術式の違けによる差異は明らかで なかった。

今回来院患者の Follow up により特に注目すべきこ とは，症状なき残存痔核，肥厚乳頭，肚門ポリープの発 現がみられ，真の所見として人工裂創 : Milligan 26例 中 5 例 19.3\%, Milligan, Parks 15例中 1 例 6.6\%, Parks 27例中 5 例 $18.5 \%$ に見られたことである.

これらのことから術後の Anal Digital Dilation によ る肛門裂創の予防と, 残存侍核などの点よりして, 結装 切除法では, 術後の患者への排便, その他の指導の必要 性のあることをここに合せて強調したいと思う。

質問社会保険中央病院隅越幸男 結禁切除住低位結禁ですか，高位ですか．

答升森茂樹

痔核切除の際は高位結柴で行っている。 


\section{（38）魚骨に起因した難治性肛囲炎 (痔瘦) 例}

\author{
外岡肛門科医院 \\ 細谷䓵夫, 外阙 君江
}

急激な肛門の疼痛を訴元る患者には，肛門管粘膜に刺 入した異物小片を，内診によりしばしば発見する，異物 片には，魚骨，竹串片，ガラス片，金属片，釣針等々， 種々あるが，特に魚骨は多く，牧野教授の統計に由れ ば，約 $20 \%$ を示している。大部分が，一部粘膜刺入例 で，内診により签易に触知，診断し得るが，魚骨片が， 粘膜. 更に粘膜下組織を破り, 馨笳内部に深く浸入した 例は少小。

われわれは最近広範な，右肛門周囲炎及び深部肛直澧 膓像を示した難治性の肛門周囲炎，それに伴亏痔瘦例に 遭遇し，その原因発症因子に苦滤した症例を経験したの で,ここに埌告する.

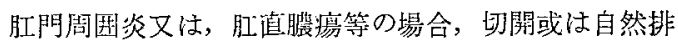
澧後には，殆んどが，瘦孔㟁成をみるが，瘦孔内孔は， 大部分が，肛門腺窝又は肛門裂創部等に起因，関連する 事が多い，即ら肚門内孔部の完全根治手術に由る侍瘦は 完全に治痹する．然し本例称回にわたる内孔根治手術 を行子も再発をりり返し, 再々度, 肛囲炎, 瘦孔形成を みた症例である。

症例壮 44 才鸟子, 農夫, 初診は, 昭和 42 年 4 月 5 日. 初診時より約 1 ケ月前に, 右肛囲に広䈇な 発赤腫 脹，疼痛及び強い歩行障害をきたしたので, 某医を訪れ， 右肛門周囲炎の診断にて，多量の抗生物質及び種々の消 炎剂を投与され，畽脹疼痛は柽快．約 3 週位で自覚症状 はとれ，某医に由る治㶹の判定を下され治療を中止し た.

治癒判定後, 約 1 週間位して, 再び右肛囲に, 発赤腫 脹をきたし，某医より当院を紹介されて来院。

当院来院時所見は，右肛囲坐骨結節を中心として，手 掌大の発赤腫脤圧痛をみるも，波動注著明ではない，硬 結は著明．内診するに，右肍門管側壁には，強い圧痛， 硬結とみるが，異物片等は触知しない，

右肛囲炎の診断にて，右肛囲，XI時部 (RA) を切開す るに, 腫脹に比して排澧は少い，1週閒経過するも，後 側方, 9 時部 $(\mathrm{RL})$ の発赤腫脹が消退しないので 1 週後 更に 9 時部切開. この際も比較的澧量は少くなかった.

4 月 25 日, 即与第 1 回切開時上り約 3 週後排膿も減少 したので, 痔瘦根治手術を行い,この際, 慎重を期して, 右内孔のみならず，左側も精查，深い腺窝は夫夕腺窝廓 清手術を行った. 術後経過は順調で, 約 3 週間で, 手術 創は治癒退院した.
退院的 4 週間後（6月10日）再度右肛囲に発赤腫脹を 見，来院した，再度 9 時部を切開したが，前回同様に腫 脹に比して, 膿量は少い. 3 日後排膿少いため, 切開創 の扡大を図ったが，この際媣部筋層を精查するに長さ約 $1.5 \mathrm{~cm}$ ，巾0.5cm 程の小魚骨を発見した。 ただちに之を 摘出：これ江由，本肛囲炎核骨に由る異物性肛囲炎 と判明した．俨骨片除去手城後は，創は比較的早期に閉 鎖，約 2 週間余で，退院した。残存魚骨の存否は旮分考 慮したが，算部全体の筋層内精查は無理な為，退院時も し肛囲に異常感ある場合は，すぐ来院するようにと申渡 しておいた。

退院後, 約 3 週間後の, 7 月 20 日忠者は再々度来院. 診るに右肚用に強い腫脹をみる，前回の経験よりして， 発赤，硬結部を中心にして，充分に局麻を行い，切開非 膿と同時に，切開創媣部の異物精查を行うに，可成樑部 より前回同様の約 $1.0 \mathrm{~cm}$ 程の小魚骨片を見出した，摘 出後は経過良好で 9 月 6 日治螇退院。

その後, 約 2 ケ年を経過したが, 肚囲には異常は見ら れないので，刺入魚骨片は，2本のみであったと推定さ れる。

魚骨は淡水系の雷魚䯚片であった。

本祉例を考按するに，肛門周囲炎の場合，発赤腫脹に 比して, 圧痛軽度, 且, 排膿少く, 波動軽微, 板状硬結像 を示寸場合汢，一応異物性肛囲炎を考虑し，切開排澧時 充分な創内腔, 及び創底等の異物精查が必要かと考え る. 淌この際, 瘦孔に沿っての, 無理な肛門管粘膜えの ゾンデ挿入は充分慎重に行うべきものと考按する.

われわれの第 2 回目に行った, 痔漊根治手術は異物存 在を全く念頭におか子加ったので，即ち，一般細菌性肛 囲炎と考えており，それに伴う痔瘦形成の考えのもとに 行ったので, 後日魚骨発見後は一考させられた.

又本例の如く, 小魚骨片に上る, 異物性肛囲炎の場合, 異物を発見した場合は，残存異物精查の為に，徒らに 創を抬大, 又は多切することなく, 残存異物の有無を, 患者によく納得させ，再度腫脹ある場合に值ちに来院す る様に伝え, 再腫脹栄を中心として, 限局性に残存異物 を，精查，摘出した方が手術創も小䉇囲ですむものと考 える.

本例は，息者が，再々度の再発手術にこりず，われわ れのもとを訪れてくれたが, もし患者が再々度の手術に こりて，次々と転医した場合は，転医治療した次医も， 又患者自身も，夫々に原因究明に可成苦しんだものと痛 く反省した症例である。

追加 渡辺元豊

私も演者と同栐な経験をした。 
(39)

\section{ブレオマイシンが著効を示した肛門癌の} 1 例

\author{
平和台病院外科
}

阿部嗅, 稻見修

悪性腫瘍に対し, 種々の化学療法㨈が試みられてきた が，屚平上皮癌に対するブレオマイシンの著効注広く知 られている. 最近, 肛門癌の一例にブレオマイシンを使 用し，著效を得たので，その概要を報告する。

患者は44才の女子, 炤和43年10月, 肛門周囲膿演の診 断で某医によって切開手術を受け，その後排膿が持続 し, 昭和 44 年 2 月から 3 月にかけ, 肺炎に䍜患し, 種々 抗生物質を用いて肺炎は治瘾したが，尚，肚門部の排膿 が持続し，硬結の消退も認められなかったので，昭和44 年 5 月 26 日当院外科比受診した.

体格, 栄養ともに良で賁血, 黄疸なく, 胸部, 腹部に 著変なし, 右下腹部には虫垂切除後の洀痕がある。尿蛋 白, 糖, ウロビリノーダン, 沈渣. 血清蛋白, ヘマトク リット, 血色素, 赤血球数, 白血球数, 白血球百分率, 血 沈等, 正常範囲で, ワッセルマン反法陰性で, 血清 $\mathrm{K}$, モイレングラハト，CCF，アルカリホスファ.ターゼ, GOT, GPT, PSP 排泄試験, 血清尿素窒素, 胸部レン トゲン写真にも異常なし，局所の試験切除は癌性変化を 示していたのでブレオマイシン療法を行うことにした.

局所の経過：スライドにはブレオマイシンを静注した 日とその量を示寸。第一日目は $5 \mathrm{mg}$, 第二, 三日目は10 $\mathrm{mg}$ ，その後は $15 \mathrm{mg}$ ，を用い総計 $220 \mathrm{mg}$ を使用した. 治療前の局所は，0 時から 3 時にかけて漬瘍を形成し， 腆苔があり，周囲に発赤と硬結が認められた。 その組織 所見は出血を伴う潰瘍部があり，潰愓底内の肉芽組織内 に散在せる扁平上皮は, 癌真珠を形成している.

潰瘍底には深く, 扁平上皮脚釘部が侵入し, 個々の細 胞はかなり成熟しているが, 癌化せるものと思う。

肉芽組織内の癌真珠の強拡大である.

脚釘部の应大で炎症反応又は再生像というよりも癌と 考えられる. 左スライドは, 癌浸潤と考える. 溃癔辺縁 部の搪大像では扇平上皮の浸潤を見る。細胞個々には著 明な異形像は認められない，ブレオマイシンを開始した ところ, 左鼠蹊部のリンパ節に局所痛と同時に注射時痛 を訴えたので, 6 月 4 日左鼠蹊リンパ腺の廓清術を行な った，組織像は全く䎐移は認められない６月11日の所 見は謴場底は肉眼上, 浅くなり, 又, 周团の硬結も減少 してきている.

その組織所見では，肉芽組織は結合織が緻密になり， 細胞浸潤も減少してきている. 扁平上皮は基底部も明瞭
で，この部分には癌化を認めることができない．6月18 日の所見では，䟺憶はさらに浅くなり，辺縁の浸潤も殆 んどなくなっている。この時の組織像は限局性に基底細 胞の増生とその乱れがあるが，浸潤像とはいいがたい．

肉芽組織内には浮腫が存在しているが, 結合織は強固 で, 毛細血管も減少している. 小円形細胞浸潤は尚, や や著明である。7月12日の局所所見で法，肉眼上，ほぼ 治瘜门近い状態である。7 月 22 日の組織所見で，屚平上 皮法脚釗部やや，長く浸入しているが，基底紐胞の限界 は明瞭で，前の浸潤せるむのと傾きが異る。 8月16日肉 眼的に治瘾した，原発部の痗痕を全て，除去し，これを 連続切片にして組織検查を行なった。スライドは，その 一部を示す.

扁平上皮は基底膜も明瞭で，全く正常のむのである。 肉芽組織は太、結合織におきかえられ，僅加に毛細血管 が残存し，その周辺に僅かな小円形練胞浸潤をみる.

以上，述べてきたように局所の所見及び組織学的所見 は,ブレオマイシン使用で著明に改善し, 全治と認めら れるに至ったが,この間, いくつかの副作用を訴えた. まず急性症状としては，注射開始より，覀心，全身の癌 㾕感, 局所痛, 頭重感, 頭痛等が見られ, 特に, 頭痛注 治療中止後む比較的長く認められた。 全身症状として は, 食欲不振, 倦急感がみられた。食欲不振は治療終了 後, 改善されたが, 倦意感は尚, 残っている. 血管の変 化は，注射部の血管の硬化が認められる．これむかなり 長く残存した，皮つ及び爪の変化としては，脱毛及び白 珐がかなり著明であったが，秃頭にはいたっていない。 その他皮フの変化, 色素沈着等が認められ, 知覚異常. 四肢の浮腫, 爪の変形等は治療終了後も残存している. 粘膜症状としては, 注射開始後, かなり, 早期から口内 炎が認められ，又，6月24日ごろから，食事の時に䫓下 腺, 耳下腺の疼痛を訴えていたが，これは早期に消退し ている. 鼻先部の発赤, 鼻粘膜の炎症はむしろ, 注射を 中止してから認められた。

又，6月下的には，腟粘膜が円筒状に脱落した. ブレオ マイシンのもっとも㧍そるべき副作用は肺合併症である が，これを早期に察知するため，かりな頻回に肺活量の 測定を行なった。湿式肺活計による測定では, 治療中, かなりのばらつきがあるが，肺活量が減じた時には，都 度, 胸部レントゲン写真を撮影した。しかし，写真上に は治療前とくらべて, 著変は認められなかった，又， 6 月の下旬には胸痛を訴えている，7月，8月にいた。 て, 治療前よりやや低下したが比較的, ばらつきの少な い肺活量が測定されている．9月初めに，スパイロメー ターで肺機能を調べてみると，パーセント肺活量は著明 な減少を認めないが，1秒率はかなり，減少しており， 
閉塞性の換気障害が推定される。この検査は街前に行な っていないので，比較することはできなかった，尚，7 月初旬より，咳嗽，喀资が著明となっている，そして， これは経過とともに，しだいに自然に軽快しつつあるが 現在でも，咳濑，喀痰が残存している，培盖ではセファ ロリジン感性の双球菌を検出しているが，発熱，胸部レ ントゲンの異常を認めていないので，積極的な治療を行 なわず，経過観察中である。その他副作用としては，㖽 声，歯の浮く感じ，特に以前に治療を受けた歯の浮く感 じ, 又, 眼瞼痛, 层部の筋硬直等を訴えている. 以上, 組織学的に明らかな肛門癌にブレオマイシンを用い，著 効を得た 1 例を報告したが，奏質臟器の副作用はほとん ど認められなかったにもかか子らず，かなり多彩な，皮 フ, 粘膜, その他の副作用を示し, 特に閉塞性の掺気障 害を思わしめた。1 1 例を報告した。

\section{（40）肛門癌 (腺癌)の 1 例}

\author{
大阪医科大学第一外科 \\ 览玉 和典，冨士原 彰
}

Anorectal の領域に癌があって原発部位がはっきりし ない場合, 一般に腺癌ならば面腸癌, 扁平上皮癌ならば 肛門癌と分類されていました。

われわれは，最近腫瘦及び組織の大部分が解剖学的に 肛門管の周囲組織内にありながら腺癌であった 1 例を経 験したので報告します。

症例．忠者は57才男で， 2 年前肛門左外側に米粒大の 腫瘤があり，これをつまむ事が出来るのに初めて気づき ましたが，何の症状もないので放置していました．約 1 カ月前からつまめなくなり，排便時肛門の内側から出張 って来る様になり，便柱が細くなってきました．約 1 週 間前排便時に桜実大の腫瘤が脱出してきたので来院しま した．排便時痛・出血等はなく，便通は1日に $4 \sim 5$ 行 ・普通便少量であります。

肛門部は外見上著変なく, 触診で 5 時の部に桜実大の ポリープ様・ザラザラした弾性硬の腫瘤をふれ，上下左 右に約 $1 \mathrm{~cm}$ 移動するだけで，肍門外えの脱出は不可能 であります，圧痛なく指の先きに少量の血液の附着があ ります。

肛門ポリープの診断で手術しました． 5 時の桜実大の 腫溜は，表面イチゴ状で大部分は内腔に突出し，腫瘤の Boden は，外側では一部肛門外皮下に及んでいますが， 大部分は内括約筋の中程まで入り込んで扔り，腫瘤底部 裹面に接して大豆大の Zystisch な部がありをした。 こ れをつけ内括約筋の 1 部を含めて腫瘤を剔出しました。

剔出標本はスライドに示す様に，イチゴ状で大部分粘 膜で被われ，約桜実大・弾性硬で制ります。zystischな 部は大豆大で, 弾性軟ゼリー様の内容を含んでいまし た.

組織学的には円柱上皮からなる腺癌で，腫琽の底部は 粘液変性が強く粘液艆の様相を呈しています。zystisch になった部の内腔には粘液にまじってくずれた腫瘍細胞 が認められます。

従来, 肛門癌は直腸癌に含めて論ぜられてきました。 その理由は肚門癌が稀にしか造遇しないといらことの他 に，肛門の概念が一定していないという事が大きい原因: をなしている様であります。

その頻度は直腸癌の $4 \%$ 前後といわれ，諸家の報告に よれば，直腸癌が男性に多いのにくらべ，肛門癌は圧倒 的に女性に多く, 又以前に肛門疾患特に侍摟に加加た 事のある者名多い。

症状は局所腫瘤の発現, 出血, 疼痛, 異物感, 便秘等 があり，早期の潰瘍形成を強調する者もいます。

発生部位は本症例の様に皮膚粘膜移行部に生ずるもの が多く，大多数扁平上皮癌で，腺癌は本邦では男 9 例， 女 4 例計 13 例が報告されていむ寸。

肛門癌の転移については各報告によって異なり一定し ませんが，大部分リンパ行性転移で，殆んど全ての例が 肛門括約筋を侵し，肛門の周囲にも若干抎がってゆき尗 寸が，直腸に向って拡大する率が多いのであります。

さて, 近年肛門部に発生した腺癌の例が報告される様 になり，又逆に直腸癌でを扁平上皮癌であったとの報告 もあります.Anorectal の領域汇澏があって原発部位が はっきり乙ない場合，扁平上皮癌は肚門癌で腺癌は直腸 癌であるという概念は再検討され，又，その解剖学的な 関係と組織像が一致しない場合には今尚種々議論されて おります。

その発生に関して, ある者江肚門腺が重大な関係をも つとのべ，又肛門腺管を重要視している人もいます。

歯状線部を組織学的に検絮すると，肛門小窝や肛門腺 管に腺細胞で被われているものもあるので，この部に腺 癌が発生しても決して扔加しくないと考えています。

本症例の場合も, 解剖学的位置と組織像からみて, 肚 門小窝・肛門腺管或は肛門腺から発生したことを充分推 測させ得ますが，ての発生母地を確定することは困難で あります，又 zyste 様になったものは，腺癌の一部が粘 液変性を生じたものと考えます。

何れにしても肛門部に発生した腺癌であり，肛門癌と しては比較的早期でめずらしく, 特にその発生母地に関 して興啐がもたれる症例であります。

今後更に症例を集娭討したいと思っています。 座長: 荒川広太郎 
肛門部の癌は㐘状腺の部分か。

答 児玉 和 典

肛門腺からの発生も充分推測させ得ます。

\section{追加}

細谷萬夫

移行部組織（肛門，或は口腔，子宮腟部）の扁平上皮 癌か, 腺癌かの判定は可成り慎重を要する。癌細胞は增 殖組織の周囲関係で可成りこれに影響される（同化，化 生) 形態を示すからである，それ故演者のいら肛門部に も腺癌が発生しても不思議ではない，但し阴平上皮部に 腺癌のある場合はその周囲を充分に組織学的に精査する 必要がある。

\section{追加伊藤良一}

皮フ粘膜移行部の構造法複雑で歯状腺を中心に皮つ粘 膜が明確に分かれているのは殆んどなく，多くが歯状腺 よりかなり口側迄扁平上皮で覆われているが中には歯状

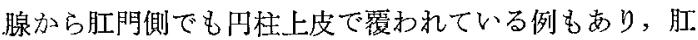
門癌が腺癌であっても扁平上皮癌で茣ってもよいはずで ある。従って肛門癌が屚平上皮澏が多いのは歯状腺より 口側迄扁平上皮でお扔わ机ている例が多いからだと考え る.

\section{（41） 肛門部癌の 2 例}

\section{日本大学石山外科}

石山 俊次, 坂 部 孝, 加藤 克彦 ○船橋 渡, 秋技 洋三, 宮本 俊雄

肛阴部良性疾患として手術を行い，組織学的検索によ り，癌と判明した 2 例を経験したので皶告します。

症例 1.26才, 男性, 主訴法排便時疼痛と肛門部出血 であります、家族歴，既往歴には特記すべき事はありせ ん.

現病歴は約 6 ケ月前上り排便時疼痛と出血を認める ようになり，出血は紙にっく程度で少量であった，発病 以来, 来院迄, 特倍療は受けておりませ九。昭和38年 8 月26日胿門ポリープの診断にて当院に入院しました。

入院時，栄養良好，眼瞼結膜に貧血は認めず，体温 正常, 胸部, 腹部に異常所見は認めません，局所所見と しては, 排便後, ポリープ先端の肛門よりの脱出がみら れる。指診では肛門括約筋の緊張は正常であり，肛門鏡 にて肛門輪より $3.0 \mathrm{~cm}$ 上方 6 時の部に有茎性のポリー プを認めます。

ロマノスコープ及び注腸によるX線検索にて，結腸， 直腸にその他のポリープは認めませんでした。

臨床検查所見は，特に異常はありません。

以上所見にて同年 8 月 28 日，ポリープの単純切除を行 った。ポリープは歯状腺直上より発して約 $3.0 \mathrm{~cm}$ の頸
を有し, 先端は随円型, 小指頭大, 淡紅色, 軟性硬, 顆 粒状で, びらん，潰瘍は認めませんでした。

組織検查にて，ポリープの先端部に腺癌の所見を認め ましたが，頸部には癌の浸潤はみられませんでした，組 織学的に根治手微であったと考え，そのまま経過観察を 行っていますが， 6 年後の現在再発の所見は誌めており ません。

症例 2，62才，男性，主訴は排便時疼痛であ.yます。 家族歴，既往歴は特記すべき事はありません。

現病歴は約20年来, 排便後及び長時閒起立時に内痔核 の肛門よりの脱出がみられ，その様な時に疼痛が增強し ております，脱出した痔核は自分で還納寸る事が出来ま したが, 10日前より嵌頓状態となり還納出来なくなった. 上記症状にて昭和 43 年10月22日当院に入院しました。

入院時, 栄恙良好, 賓血なく, 体温正常, 胸部, 腹部 に異常所見なく，血圧，心電図にも異常は認めませんで Lた.

臨床検査所見にも異常はみられません，

局所所見は内痔核の嵌頓状態で, 全周にわたり浮腫状 で発赤腫脹強く，11時の部に硬い腫瘤状の硬結と中心部 に潰瘍を認めた，全体に炎症症状が強かった為，抗生物 質の投与とリゾール浴を行い，炎症症状が晫快した入院 1 週問後に手術を行った。

手術は 3 時, 7 時, 11 時の 3 ケ所で結紮切除術を行い ました１1時の部にあった侍核溃湯を形成し，その周 囲に比較的硬い浸潤を認め，手術時に悪性腫嚐を疑っ て,この部はやや大きく切除を行った

組織所見は扁平上皮癌で，切除断端にも癌の浸潤が認 められました。

そこで患者の都合により，1 月月後に根治手術の目的 で直腸切断術，人工肛門造設を行った。この際肛門部皮 膚汢意識的に広く切除しました。

肛門部皮䖉及び皮下組織には, 組織所見で癌の浸潤は みられず，切除せる直腸粘膜に注異常所見はみられない が，直腸の組織学的検索にて，歯状線より約 $4.0 \mathrm{~cm}$ 口 側の筋層内汇扁平上皮癌の転移を認めました。な祝獎 膜, 切除断端には癌の浸潤はみられませんでした。

術後再発防止の目的で, $\beta$-トロン, 総量 $3000 \gamma$ を両側 でソケイ部に照射した。な拈術後の経過は良好で，9ケ 月後の現在健在であります。

以上の如き症例を報告しましたが，肛門癌の頻度㤬， 比較的稀れであり，Bacon は直腸䍄2.160例に対し，71例 (3.2\%), Sweet は直腸癌 802例に対し，38例(4.7\%) 等の報告がみられ，本邦で注，東邦大学，小平外科の直 腸以下の癌73例, うち肛門癌11例(15.1\%), 東北大学, 棋外科の直腸以下の癌， 215 例のうち 7 例 $(3.0 \%)$ に肛 
門燰を認めたと報告しております。おれわれの教室で は, 淔晹癌59例に対し, 肛門癌 2 例 (3.4\%) で, その比 率は他の報告と大体類似しております。

本邦に於いては，痔瘦より発生したと思われる肛門癌 が多く，これは痔瘦が慢性な疾患で長期閒放置されがち である事に原因がある様であり，われわれが経験した侍 核を伴った第 2 例では，20年しいう長期間，繰り返して おこった。 ビラン，裂肛等が原因となったとも考えられ ます，な抗この症例では，根治手術時の標本で，肛門部 皮膚及び，皮下組織に癌浸潤が全くみられなかったにも

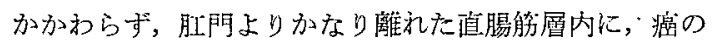
転移所見を組織検查により認めた事は，根治手術にあた り充分注意要する点と考えます。

一方ポリープの琹性化については, ポリポージスに恶 性化の傾向が強く, 組織学的には, 腺腫性ポリープ, 特 に緎毛状乳頭腫に癌化の頻度が高い様であります，われ われの経験した第 1 例のポリープ虞は, 年令的に, 26才 と若く, 病脳期閒が短く, 組織学的には, 悪性度の低、 癌であります。

この症例についての治療でありますが, ポリープの単 純切除術のみにて, 厳重に経過を観察し, 6 年後の現在 も, 再発も所見を認めていませんが, 今後この様な症例 のあった場合, さらに, 根治的手術を行うべきか否かに 問題があると考えます。

最後に, 今回報告した 2 症例は, われわれ臨床医が普 段肛門部の良性疾患として安易に手街を行うような症例 ですが，組織学的検索にて癌と判明する場合もあり，そ の点, 局所の注意媣、観察と組織学的検索が必要と考え ます。抒解剖学的に肚門の䉕囲についての考え方は, 多少の違いがある様であり, よって肛門溜の解䣋も一律 でない様であるがこの部に発生する癌には組織学的に 扁平上皮癌も腺癌も含まれるものと思う。

肛門癌法非常に少ない疾患でありますので，今後の研 究方針として，多くの施設加症例集めて多数の症例 について検尌する必要があると考えます。

質問 小 平 正

演者のお話し下さった例は貴重なものだと思います。

局所切除後に直腸切断術をして上方壁内にも唡平上皮癌 細胞をみつ汁ととらことですから立謂, 肞門癌の小さ なものの局所切除をもって充分だといら見解がもしある としたらそういう考えは矢張り考え数ばならないことだ と思う。

癌研の梶谷先生のこの点に関する御意見と御教示を願 いたいと思います。

な扔へモロイドに対する切除後の検査もむっと意欲的 にすすめてみたいものと考党ます。
私は Dentate lineより上方は脰大部下部の方にいれ ていたので肚門澏の頻度は低く, 経験も少い，扁平上皮 癌が主であったが，上方まで入れると腺癌も多くなる， 進行した肚門癌の予後は芳しくない。

発生原因として私は痔核よりの癌化例を経験してな い. 痔瘦の癌化例と思われる 2 例をもっているが，これ も病歴より想像したもので組織学的化明らかにすること は困難であった，唯今の侍榜よりの癌或は肚門腺よりの 癌化は貴重な報告である。

治療法として私は直晹切断をやって来た．御発表の局 所の切除はあの程度進んだものでは不充分かと思いま 寸。

肛門癌では経験がありませんが直腸では有怲の悪性ポ リープで悪性度の低い樑部增殖傾向の少ないものでは局 所切除でよいものがある。

\section{（42）生後 7 時間で手術を行なった 新生児巨大 仙尾奇形腫の一治験例}

\author{
国立小児病院第一外科 (沢口) \\ ○堀隆, 沢口 重徳, 中條 俊夫 \\ 太田 昌吾
}

われわれは最近, 出生当日の新生児の巨大な仙尾部夸 形腫の手術例を経験しましたので報告致します.

症例は女児であります，雨親は29才と27才でともに健 康です，初回娃娠で2ケ月拉よび3ケ月垻に，プレマリ ン, 新 $\mathrm{EP}$ ホルモン，プリンペランなどの薬物を服用 しております他は，特に異常はありませんでした。

昭和 44 年 3 月 25 日, 予定日より 20 日早く, 帝王切開で 出産しております．出生と同時に仙尾部の巨大睡瘤に気 ずかれました，生下時体重は $6200 \mathrm{~g}$ でありましたので， 体重とほぼ同じ位の腫溜がついていたことになります。 直ちに当科に紹介され入院致しました.

スライドは入院時の所見であります，腫瘤は横径 25 $\mathrm{cm}$, 綖径 $17 \mathrm{~cm}$ ，厚さ $10 \mathrm{~cm}$ の巨大なもので，表面は皮䖉 に被わ机平滑，一部に波動を子れます。概数顿かいが, 一 部に硬い部分る㐫ります，肛阿は前方に押されて前面か らよく見え，meconium の排泄がみられて抢りました。

全身状態注概称良好で合併奇形はありませ几，入院時 の体重は6050g, 胸囲 $33.5 \mathrm{~cm}$, 頭国 $35 \mathrm{~cm}$ であります。 身長は下肢が腫瘁につかえて伸儌しないため測定出来ま せん. 呼吸数 44 , 脈拍 114 , 体温がやや低くて $35.4^{\circ} \mathrm{C} て ゙$ ありましたので直ちに哺育器に収容しました。

スライドは入院時のX線写真です。フィルムに全身が 入り切ら゙ず，2枚にわけて撮影しました。腫瑠のほぼ笊 
央に不規則な形の石灰化像があり，奇形腫と診断しまし た.

手術は生後 6 時閒46分で行なわれました．体位は腫場 があまりに大きいため，们卧位のままとし，下半身を全 部マーゾニンアルニールで消毒しました，麻酔は笑気に よる気管内秝酔で行いました，スライドのように，皮覻 を十分残すように腫痬上に皮虔切開を拉き，もっぱら針 的に剥離を進めました，剝離はかなり容易に行われるし たが, 肛門括約筋, 肛門举筋は圧迫されて菲薄となって おり，また直腸後壁は腫場に接しているので，これらを

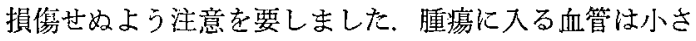
く，大血管注認められませんでした，尾骨を含めて腫瘍 を剔出後，Levatormuskel を互いに縫等世，骨盤底の 補強を行いました，手術時間は1時間19分で，麻醉時間 1 時間50分, 出血量は $190 \mathrm{cc}$ で同量の輸血が行われま した.

スライドは剔出標本でこのように複雑な構造を示して おります。

術後は，排泄物による創の污染を防止するため，腹卧 位に保ったまま哺育器内に収容しました，器内の温度は $29^{\circ} \sim 30^{\circ} \mathrm{C}$ とし酸素によるネブライザーを 1 日行いまし た。輸液は $1 / 5$ 生食を $50 \mathrm{cc} / \mathrm{kg} 1$ 日行いむした。術後 3 時 間で排尿があり，12時間で排便がみられました，術後 2 日目より経口投与を行い，图のように順調に噼乳量が増 加しております。な扔，抗生物質として Pentrex 200 mg/日および Ceporan 120mg/日の筋注を用いました. 術後経過は順調で，27日目に全治退院しました。

また体重は，右スライドに示したように，入院時 $6050 \mathrm{~g}$ で，腫演剔除後3200g となっておりますので，腫掦の重 さは約 $2850 \mathrm{~g}$ であります，その後の体重增加は願調であ ります。

スライドは退院時の写真です.

5 ケ月現在, 毎日規則的な排便があり, 直腫㧍よび膀 胼障害注ありません，肛門括約筋の tonus は良好であ ります。また下肢の異常む認められません。、スライドは 4 ケ月の時のもので, 体重は $8.2 \mathrm{~kg}$ であります.

スライド左は, 剔出標本の大半を占める中枢神経組織 (glia)です，右はその強掂大であります.

左は皮膚成分で，毛集，皮脂腺が双られます，右は唾 液腺, 平滑筋などがみられる部分です。

左スライドは呼吸上皮(線毛上皮)，重層扁平上皮がみ られて捛ります。

右は消化管成分で結腸の队柱上皮，腺などがありま す.

この他, 骨, 軟骨, 骨髄, 脂肪組織, 勝などを含んで おりますが，いずれも成人組織に類似した構造を示し，
未熟な組織成分は認められませんでした。

仙尾部悪性奇形腫は屡々悪性化を来すことが知られて おります. Hickey らは1938年から1953年までの文献上, 112例を集め, 悪性化したものの頻度を調べております が，生後4 ケ月までは $5 \%$ であるに対し，4 ケ月以上15 才までは，64\%に悪性化がみられた，上報告して扔りま す. 更に Woldhausen らは1953年以後1963年までを集 計し，4 ケ月以前では悪性は $7 \%$ であるに対し，4ケ月 以上では $42 \%$ の高率に悪性化がみられることをのべてお ります。

また Hoffman らは两性仙尾奇形腫43例を集詝し1才 半頃の症例が多いことを報告して肪ります.

これらのことから, 本症の治療にあたっては常に恵性 化する，あるいはすでに悪性化している危險性を考慮に 入れる必要があります. McCune (1964) のように新生 児に本症がみられた場合，生後数時間以内に剔出するべ きであるという人もあり，早期手術が望ましいと考えら れます。

本症は屡々疑告されており，決して稀なものではあり ませんが，本例のように巨大なもの珍らしく，われわ れが調べた得た文献中，新生児の手術例では最大のもの でありましたのでここに報告させて載きました.

\section{（43）私の肛門病治療方針}

福成県

豊 永 敬一郎

私は非観血療法主に腐蝕注射療法を行なっている，戦 前迄はメスを以って切開縫合する镜血瘵法が肚門治療の 主流をなし注射療法はインチキ療法として異端視される 時代があったが現在では我が学会でも盛んに注射療法が 発表されその優秀性も高く評洒されている. 然るに未だ 一部の専門家, 学者の中には腐蝕注射療法を以て悪法の 最たるものときめつける人があるが，それは腐蝕療法な るものを知らぬ人の暴言であって，誠に遺感に䓵えな い，ホワイトヘッド氏法等の切除綘合法は化膿をおこし 易くまた肛門狭䂟粘膜脱出失禁等の不愉快な後遺症に悩 まされることが多いのに反し，我が注射痖法法化澧将痛 出血が比皎になら程少ない，従って入院治療の要なく 外来で処置出来, 軽度のもの注勤労しながら治潦出来る

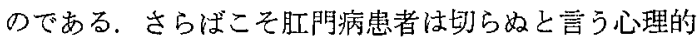
な面もあるが，私の様な非観血療法をやる医院の門をよ り多く印くのである。現今ではホワイトヘッド氏法の如 きは前世紀の歴史的療法として雇みない専閶家が多くな ったのもむべなるかなである，私の病院でも注射療法を 好んで行なっている，注射後10日位で患部が腐蝕脱落し 
開放創となり瘦痕を形成し治澺する、洔溲の場合もメス を用いまたは縫合したりしない，徹底的に焼昫し大きな 開放創を作り肉芽形成を持つ, 最近数年間数多くの例在 取り扱ったが後遺症を残寸恶結果になった例がない。も ちろんこの療法流度の技術を要することは論をまたな い. 何の経験もなく、いきなり腐蝕注射療法を行えば重 大な結果を来すことがあるので充分な研究と慎重な態度 でなくてはならない，私も初期には数多くの失敗例があ る. 最近数年間は失敗例なく私の技術は神技任近いもの と自他共に許している，然しながらその療法も健疗保険 には末だ十分取り入れられていない，従ってかかる療法 を行なっている医師は保険外でやっている，私の病院も 保険医療機関でなく自費診療である。願わくば一日も早 く保険診療出来る様な施策の樹立を切に望むものである 裂肛を合わせると全体の約 $90 \%$ 占めることは前回と同 様であるが，特筫が10\%少なく裂肚が $11.3 \%$ 多くなって いる。

治療法にっいては, 手術を行ったものは, 肛門疾患総 数, 約 $25,000027 \%$ そ, そのうち $95 \%$ は入院して行なっ ている. 又注射療法はその $98 \%$ 迄吕肛門専門の私立病院 で行なわれているが, 大学で 5 病院, 国公立で 3 病院, 計 83件に行なわれているのは興味深い，注射療法の後遺症 を多くみているわれわれには，その整害のみが強調され て感じられているが，正しい認識のもとに適応をえらん で行なえば，その效果も充分期待できるものと信ずる.

将核の手術については，10年前に殆んど行なわれてい なかった結㷊切除法が49病院（57\%）で行なわれている ことは非常な変化である.しかしなお，45病院（52\%） ではホワイトヘッド手術が行なわれている。痔㙫, 裂肛 に関しては余り変わりなく, 開放創として処理されて いる. その他, 麻酔法, 手術体位, 手術前後の処置, 直 腸脱, 肛門ポリーブ, 良性腫湟, 肛門癌, 鎖肛, 肛門狭 宱, 術後障害, その他の頻度等についての心゙る。

\section{（44）肛門疾患治療の現況}

社会保険中央総合病院

隅越 幸男, 高野 正博

昭和33年, 第13回本学会に执いて, 小平教授が，91の 大学，国公立病院の資料をもとに，肛門疾患の外科療法 と題して，特別講演をされた. その後約 10 年を経た今 日，肛門疾患のとりあつかい方がどのように変化してき をかを知ることは，大変興味あることと考え，われわれ は，昭和42年度にとりあつかわれた肚門疾患について調 查し，質問用紙に記入された事項について 集計を行っ た. 回答を得た施設は, 大学 21 , 国公立病院 57 , 私立病
院 8 計86で,これらの統計を10年前のそれと比較して御 覧にいれたいと思う（御回答下さった施設名を列記さ せていただく)

なお病院のベッド数は表1のごとくで，100朱以下は

表 1 病院の病床数

\begin{tabular}{|c|c|c|c|c|c|}
\hline 病 & 床 数 & 大 学 & 国公立 & 私立 & 計 \\
\hline 300 & 0 床以上 & 20 & 19 & 1 & 40 \\
\hline 101 & 1 300林 & 1 & 34 & 2 & 37 \\
\hline \multicolumn{2}{|c|}{00 床以下 } & 0 & 2 & 5 & 7 \\
\hline \multirow[t]{2}{*}{ 不 } & 明 & 0 & 2 & 0 & 2 \\
\hline & & 21 & 57 & 8 & 86 \\
\hline
\end{tabular}

7 施設 $(8 \%)$ で, 殆んどが病床数の多い病院である.

1) 肚門疾患の頻度

86施設のうち，本項目の記載不明確なものをのぞいた 75施設についてしらべた。一般外科患者数（肛門疾患を のぞく）は $221,591 て ゙$ 肚門疾患患々者数は 27,303 , その 比は 8.1: 1である. これを大学, 国公立, 私立病院に わけてみると，前 2 者と後者とでは非常な鋅がある。.大 学, 国公立病院のような総合病院では14〜18：1の比率 である. 私立病院で肛門疾患が正倒的に多いのは，肛門 専閭病院が含まれているためである。（表2）

表 2 肛門疾患の頻度

\begin{tabular}{|c|c|c|c|}
\hline 病 & $\begin{array}{l}\text { 一般外科 } \\
\text { 患 者 数 }\end{array}$ & $\begin{array}{l}\text { 肛門疾患 } \\
\text { 患者数 }\end{array}$ & 比 \\
\hline 大 学 $\left(\frac{20}{21}\right)$ & 63.744 & 3.501 & $18.2 ; 1$ \\
\hline 国公立 $\left(\frac{48}{57}\right)$ & 139.686 & 9.868 & $14.2 ; 1$ \\
\hline 私 立 $\left(\frac{7}{8}\right)$ & 18.161 & 13.934 & $1.3 ; 1$ \\
\hline 計 $\left(\frac{75}{86}\right)$ & 221.591 & 27.303 & $8.1 ; 1$ \\
\hline
\end{tabular}

2) 肚門疾患の種類

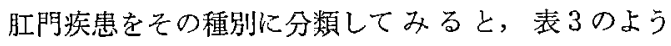
になる。（記載の明らかな81施設の集計）外ぢ核, 内ぢ 核，脱肛を含めて，ぢ核として一括してみるとこれら は全体の66.5\%で，10年前（表 4）とほぼ同じ比率であ り，直腸肛門周囲脤湟をふくめた，ぢ洝については13.5 \%と $10 \%$ 少なく，裂肛は $11.3 \%$ と多少多い比率となって いる. 大学, 国公立, 私立病院についても表 5 の如く, 3 疾患の比率は余り変りなく, これらの合計は, 全肛門 疾患の約 $90 \%$ を占めることは前回と同㥞である.

3）治療法の種別

肛門疾患の治療を保存療法, 注射療法, 手術療法にわ 
表 3 肚門疾患の種類 $\left(\frac{81}{86}\right)$

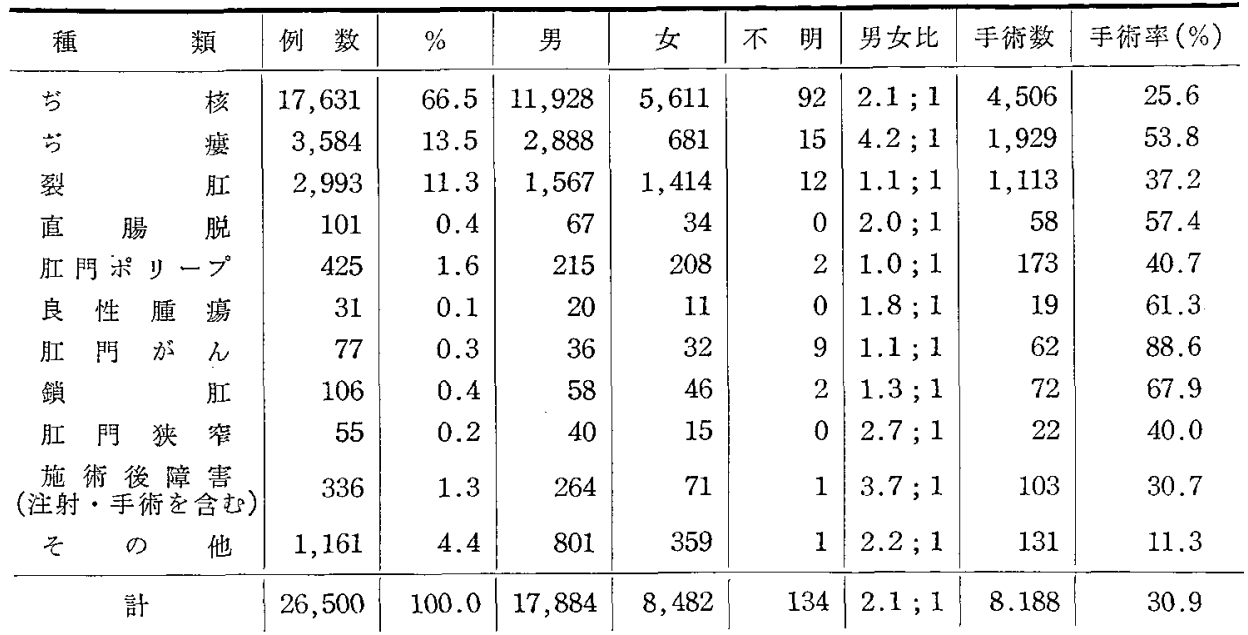

表 4 肛門疾患の種類と頻度 (昭和 32 年度 91 病院)

\begin{tabular}{|c|c|c|c|c|c|}
\hline & 例数 & $\%$ & 男 & 女 & 比 \\
\hline 外占核 & 2,391 & 19.8 & 1705 & 686 & $2.5 ; 1$ \\
\hline ち 核 & 5,304 & 43.8 & 4180 & 1124 & $3.7 ; 1$ \\
\hline 瘦 & 1,785 & 14.8 & 1408 & 377 & $3.7 ; 1$ \\
\hline 肍 囲 膿 疡 & 1,025 & 8.5 & 750 & 275 & $2.7 ; 1$ \\
\hline 裂肛 & 866 & 7.2 & 496 & 370 & $1.3 ; 1$ \\
\hline 直 腸 脱 & 253 & 2.1 & 190 & 63 & $3.1 ; 1$ \\
\hline 肛 門 が h & 104 & 0.9 & 58 & 46 & $1.3 ; 1$ \\
\hline ポリープその他 & 128 & 1.1 & 95 & 33 & $2.9 ; 1$ \\
\hline 鎖 肛 直 腸 閉鎖 & 59 & 0.5 & 33 & 26 & $1.3 ; 1$ \\
\hline 後天性 狭窄 & 102 & 0.8 & 78 & 24 & $3.2 ; 1$ \\
\hline $\begin{array}{l}\text { 非観血的療法 } \\
\text { 施術後障害 }\end{array}$ & 78 & 0.6 & 64 & 14 & $4.5 ; 1$ \\
\hline & & 100 & 9057 & 3038 & \\
\hline
\end{tabular}

けてみると表 6 のようになる．注射療法の大部分は，外 来で行なわれ，その $98 \%$ は肛門專間の私立病院で行なわ れている．しかし大学病院で，5施設，44件, 国公立病 院で 3 施設，39件に注射療法が行なわれているのは興味

表 5 病院別分類

\begin{tabular}{|c|c|c|c|c|c|c|c|}
\hline & \multicolumn{2}{|c|}{ 大学 $\left(\frac{21}{21}\right)$} & \multicolumn{2}{|c|}{ 国公立 $\left(\frac{54}{57}\right)$} & \multicolumn{2}{|c|}{ 私立 $\left(\frac{6}{8}\right)$} \\
\hline & & 例数 & $\%$ & 例数 & $\%$ & 例数 & $\%$ \\
\hline 占 & 核 & 2155 & 65.2 & 6.407 & 64.9 & 9069 & 68.0 \\
\hline ち & 㿉 & 510 & 15.4 & 1.460 & 14.8 & 1641 & 12.1 \\
\hline 裂 & 肛 & 261 & 7.9 & 1.270 & 12.9 & 1462 & 11.0 \\
\hline
\end{tabular}

表 6 治療法の分類

\begin{tabular}{|c|c|c|c|c|c|c|}
\hline & $\begin{array}{l}\text { 大学 } \\
\left(\frac{18}{21}\right)\end{array}$ & $\begin{array}{l}\text { 国公立 } \\
\left(\frac{51}{57}\right)\end{array}$ & $\begin{array}{l}\text { 私立 } \\
\left(\frac{6}{8}\right)\end{array}$ & 計 & $\begin{array}{l}\text { 合 } \\
\text { 誩 }\end{array}$ & $\begin{array}{l}\text { 総 } \\
\text { 計 }\end{array}$ \\
\hline 外 $\left\{\begin{array}{l}\text { 保存療法 } \\
\text { 注射療法 } \\
\text { 手術療法 }\end{array}\right.$ & $\begin{array}{r}2376 \\
41 \\
117\end{array}$ & $\begin{array}{r}7941 \\
39 \\
163\end{array}$ & $\begin{array}{r}3639 \\
4142 \\
47\end{array}$ & $\begin{array}{r}13956 \\
4222 \\
327\end{array}$ & 18505 & \multirow{2}{*}{25.064} \\
\hline 入 $\left\{\begin{array}{l}\text { 保存療法 } \\
\text { 注射潦法 } \\
\text { 手術療法 }\end{array}\right.$ & $\begin{array}{r}17 \\
3 \\
496\end{array}$ & $\begin{array}{r}62 \\
0 \\
2764\end{array}$ & $\begin{array}{r}64 \\
0 \\
3153\end{array}$ & $\begin{array}{r}143 \\
3 \\
6413\end{array}$ & 6559 & \\
\hline
\end{tabular}

深い，本法の後遗症を多くみているわれわれには，その 弊害のみが強調されて感じられているが，正しい認識の もとに適応をえらんで行えば，その効果注充分期待でき るものと信ずる. 又手術の行われたものは，6740件で肛 門疾患総数 $25064 の 26.9 \%$ であり，その $95 \%$ は入院して 行われている.

次に各疾患についてのベる.

4) ち核

ら゙核17，631例中，手術が行われたもの 4,506の25.6\% で，前回の $42 \%$ に比べ少い，ぢ核は相当，保存療法でお さまるもので，直ちに手術を行なわねばならぬものは， 少ない，われわれは第而度，即ち常に脱出しているもの で，日常生活に支障をきたするの，保存療法によって， 出血のとまらないもの，劣るいは反覆するものにとどめ ている, 又急性期の腫脹, 疼痛をともなうものも, 保存 療法で自党症状がとれればあえて手術をすすめない，集 計された術式についてのべると，表 7 のごとく結禁切除 法が $49(57 \%)$ の病院で行なわれている，10年前には殆ん 
表 7 内方核手術法(施設数)

\begin{tabular}{l|c|c|c|c}
\hline & 大 学 & 国公立 & 私立 & 計 \\
\hline $\begin{array}{l}\text { ホワイトへッド } \\
\text { 及びその変法 }\end{array}$ & 11 & 31 & 3 & 45 \\
$\begin{array}{l}\text { ブラーッ及びそ } \\
\text { の変法 }\end{array}$ & 14 & 25 & 1 & 40 \\
結禁切除 法 & 10 & 33 & 6 & 49 \\
そ & 3 & 1 & 1 & 5
\end{tabular}

ど，ホワイトヘッド及びその療法か，ブラーツ及びその 変法であって，結紮切除法が行われているとこころは極 めて僅かであった。しかしまだホワイトヘッド手術も過 半数の病院 $(86$ のうち $45(52 \%))$ で行われている。われわ れは 9 年間に66のホワイトヘッド後遺症をあつかい: そ のうちわけは肛門狭窟17, 直腸粘膜脱49となっている。 これらはそれぞれ肛門成形術を行い，改善されたが，高 度のものは，その修復は湛だ難かしく，满足すべき機能 の回復は望めない，手術を行うならば，肚門生理機能を そこなわ術式をえらぶべきである。

5) ぢ痤

肛囲膿瘍をふくめて，ぢ㿉の手術は3584例中 1929 (53.8\%)に行われている. 術式的以前と大差なく, 瘦管 を切開, 搔爬，あるいは剔出して，開放創とするか，一

表 8 ち洎の手術法(施設数)

\begin{tabular}{|c|c|c|c|c|}
\hline & 大 学 & 国公立 & 私 立 & 計 \\
\hline 瘦 管 切 開 & 8 & 34 & 3 & 45 \\
\hline 瘦 管 剔 出 & 19 & 39 & 4 & 62 \\
\hline 開放創とする & 12 & 33 & 8 & 53 \\
\hline 縫 合する & 4 & 5 & 0 & 9 \\
\hline
\end{tabular}

次的に縫合するかであるが，表 8 のごとく開放創として いるところが大部分である、ぢ霓を確実に治すには，注 射療法その他も㐫万らが，これは主として単純ら゙瘦が対 象で，根治的には，手術的に行うべきであろう。その原 発口に対する処犆を確実に行って，瘦管を開放し，二次的 に行う方法が最もよいと思う。ただ表在性の簡単なもの で，索状物がふれるだけで，原発口も殆んど肉眼的には 著明できない状態で，㿉管より分泌物もなく，長い閒お さまっており，自覚症状も全くないような場合は，その まま放置して，あえて瘦管に対する処置はいらないと思 う. ち瘦と結核との問題は10年前と大部変り, 現在では, 結核性ぢ瘦は激减したことは乿知のとおりである。問題 はら゙瘦とがんとの関係で，少数例ではあるが報告がみら れる、われわれも経験しているが，これは30年近くもぢ
㾇の再発をとりかえしていたものである。しかし短期間 に悪性化する危険もあるのでぢ瘦の再発をくりかえすも のは，確実にその根源をたっておくべきである．

6) 裂肛

裂肞2993例中手術をしたものは1113例（37.2\%）で術 式は, 表 9 の如く, 切除して開放創としている病院が，

表 9 裂肚の手術法 (施設数)

\begin{tabular}{|c|c|c|c|c|}
\hline & 大学 & 国全立 & 私立 & 計 \\
\hline 一次繸 合 & 4 & 12 & 3 & 19 \\
\hline 開 放 創 & 12 & 37 & 6 & 55 \\
\hline そ の 他 & 3 & 7 & 0 & 10 \\
\hline
\end{tabular}

55 （65.5\%）で最も多いわれわれは，裂肛はその殁ん どが，多少なりとも肛門狭窄をともなっているので，そ の症痕を切除し，肛門を拉張して，創面に皮膚移動を行 っているが非常に経過がよい.

7）麻酷法

表10のごとく，麻醉は，腰麻，又はサドルブロックを 表 10 麻酔法 (施設数)

\begin{tabular}{|c|c|c|c|c|}
\hline & 大 学 & 国公立 & 私立 & 計 \\
\hline 局 & 2 & 0 & 2 & 4 \\
\hline 静 脈 麻 酥 & 0 & 0 & 0 & 0 \\
\hline 麻 & 9 & 35 & 5 & 49 \\
\hline サドルブロック & 18 & 36 & 3 & 57 \\
\hline 仙 & 1 & 0 & 0 & 1 \\
\hline トランスサクラル & 0 & 1 & 0 & 1 \\
\hline 全㫘 & 4 & 0 & 0 & 4 \\
\hline
\end{tabular}

用いているところが大部分である，欧米では全麻が主と して行われているが，わが国では殆んど腰麻であること は，昔も今も変りがない．

8) 手術体位

手術体位については表11のごとく依然として砕石位が 圧倒的に多い。しかしジャックナイフ体位をとってい る病院が19もあるのは，10年前と大賕な違いである．当 時, 手術野が広くて手術が行いやすいとして, 砕石位を

表 11 手術体位（施設数）

\begin{tabular}{|c|c|c|c|c|c|}
\hline & & 大 学 & 国公立 & 私 立 & 計 \\
\hline 砕 & 石 位 & 21 & 48 & 6 & 75 \\
\hline $\begin{array}{l}\text { 泍ヤッ } \\
\text { 体 }\end{array}$ & $\begin{array}{r}\text { クナイフ } \\
\text { 位 }\end{array}$ & 5 & 12 & 2 & 19 \\
\hline Sims & 位 & 0 & 0 & 1 & I \\
\hline そ & の & 0 & 1 & 0 & 1 \\
\hline
\end{tabular}


とっておられた小平教授す今ではジャックナイフ体位を すすめて抢られる。われわれもずっとこの体位をとっ ており，砕石位より種々の点で有利であることは再々報 告したとおりである，今後拉そらくこの体位をとる術者 がふえることと思う。

9) 手術前処置

表12のごとく術前の処置として下剤を投与しているの は大学病院に多い，食期は手術当日の朝だけたべさせな

表 12 術前処置（施設数）

\begin{tabular}{|c|c|c|c|c|c|}
\hline & & 大学 & 国公立 & 私立 & 計 \\
\hline \multirow{2}{*}{$\begin{array}{l}\text { 下痢 } \\
\text { 投与 }\end{array}$} & $\Phi$ & 18 & 28 & 3 & 49 \\
\hline & L $\overbrace{}^{2}$ & 3 & 28 & 5 & 36 \\
\hline \multirow{3}{*}{ 絶食 } & 前夜加 ら & 7. & 5 & 0 & 12 \\
\hline & 手術朝のみ & 15 & 48 & 6 & 69 \\
\hline & しない & 0 & 2 & 2 & 4 \\
\hline \multirow{4}{*}{ 浣腸 } & 前夜と手術日 & 13 & 13 & 2 & 29 \\
\hline & 手術日の功 & 8 & 38 & 5 & 53 \\
\hline & ᄂなW & 0 & 4 & 1 & 5 \\
\hline & そ の & 0 & 1 & 0 & 1 \\
\hline
\end{tabular}

いところが大部分である，浣腸も手術当日の朝にだけ 行っているところが最を多い，浣腸をしない病院が $5 つ$ もあったが，これはそれに代る方法がとられているのか もしれない，われわれはふつう肚門疾患の手術前にはレ シカルボン坐剤を浣腸の代りに用いて，おおむる目的を 達している，術前検查として，われわれはルチーンには 血液，尿の一般検查を行い，必要があれば，肝機能，心 電図，胸部その他のレ線検查なども行っているが，これ らに関しては特に調查はしなかった。

10)手術後の処置

肛門疾患手術後注創感染の予防にできるだけ排便を拉 くらせる必要があった。 しかし現在では，術式の変化に ともない閉鎖法が少なくなったため，早期排便がいっこ う差支えないことになった。したがって術後の食䬣制限 についても，以前のように厳格ではなくなった．表13の ごとく，手術当日か翌日まで食慨制限を行ってあとは子 つうに食べさせている．全く制限をしていない病院もあ る.これは10年前と非常に変ってきている点で, 当時は 術後 $3 \sim 4$ 日間流動食をとらせていた。 そしてアへンチ ンキを与えて 1 週前後の排便をさせていた. しかし現在 では57の病院 $(68 \%)$ がアヘンチンキを使用せず，過半 数46 (55\%) が排便抑制をしていない.われわれるアへ ンチンキは普通用いない，それでむ術後 $2 \sim 3$ 日は排便 をみない，食䬺制限も特にせず，手術翌日に全棏を与え たベられればすぐ常食をとらせている。
表 13 術後処置 (施設数)

\begin{tabular}{|c|c|c|c|c|c|}
\hline & & 大学 & 国公立 & 私立 & 計 \\
\hline \multirow{2}{*}{ 食 } & ᄂ ない & 3 & 7 & 2 & 12 \\
\hline & 手術当日のみ & 4 & 23 & 2 & 29 \\
\hline 餌 & 手術の翌日まて & 10 & 17 & 4 & 31 \\
\hline 制 & 術後 2 日まで & 2 & 4 & 0 & 6 \\
\hline \multirow{2}{*}{ 限 } & 術後 3 日まで & 2 & 4 & 0 & 6 \\
\hline & 術後 4 日まで & 0 & 1 & 0 & 1 \\
\hline \multirow{3}{*}{ 排 } & し な & 9 & 32 & 5 & 46 \\
\hline & 手術当日のみ & 0 & 0 & 0 & 0 \\
\hline & 手術の翌日まで & 0 & 1 & 1 & 2 \\
\hline \multirow[t]{2}{*}{ 便 } & 術後 2 日まで & 1 & 1 & 0 & 2 \\
\hline & 㣺後 3 日まで & 4 & 4 & 0 & 8 \\
\hline 抑 & 術後 4 日まで & 2 & 9 & 1 & 12 \\
\hline \multirow{3}{*}{ 制 } & 術後 5 日まで & 2 & 4 & 0 & 6 \\
\hline & 術後 6 日まで & 2 & 2 & 0 & 4 \\
\hline & 術後 7 日まで & 0 & 3 & 0 & 3 \\
\hline \multirow{2}{*}{$\begin{array}{l}\text { 阿ン使 } \\
\text { 片 } \\
\text { 千キ用 }\end{array}$} & ᄂ な & 12 & 38 & 7 & 57 \\
\hline & $\frac{1}{9}$ & 10 & 16 & 1 & 27 \\
\hline
\end{tabular}

11）直腸脱

回答された值腸脱の手術法は表14にしめすようにいる

表 14 直腸脱の手術法（施設数）

\begin{tabular}{|c|c|c|c|c|}
\hline & 大学 & 国公立 & 私 立 & 計 \\
\hline チールシ & 6 & 10 & 4 & 20 \\
\hline レーンデロルメ & 1 & 6 & 0 & 7 \\
\hline 直 腸 固 定 & 12 & 10 & 2 & 24 \\
\hline 骨盤底形成 & 5 & 5 & 0 & 10 \\
\hline そ $\quad$ 他 & 0 & 0 & 1 & 1 \\
\hline
\end{tabular}

いろあり，更にそれぞれを組合せたものも行なわれてい る，それだけ一つで確実な力法がないといえる．開腹し て，骨盤底形成を行い，直腸を固定する方法が最も根治 的と思うが，程度，年令などによっては，簡単な方法で すをす場合もあるう。

12) 肛門がん

肚門がん淔腸がんに比心，稀で Grinnell の統計に 上ると，大腸がんの $1.8 \%$ ，直腸肛門部がんの $4 \%$ であ る.肚門がんの定義もはっきりとしておらず，扁平上皮 がんをもってそれとする学者もあれば，肚門に発生した がんを，肛門がんと称するという学者もある，したがっ て，腺がんも肛門部に発生して陉れば肛門がんに含める わけである. 今回の集計ではそのいうれれよって出され たかは施りとはしないが，表15の如く総数は77例で， 保存的ないし人肛門のみに㧍わったものが33例であ 
表 15 肛門がん（症例数）

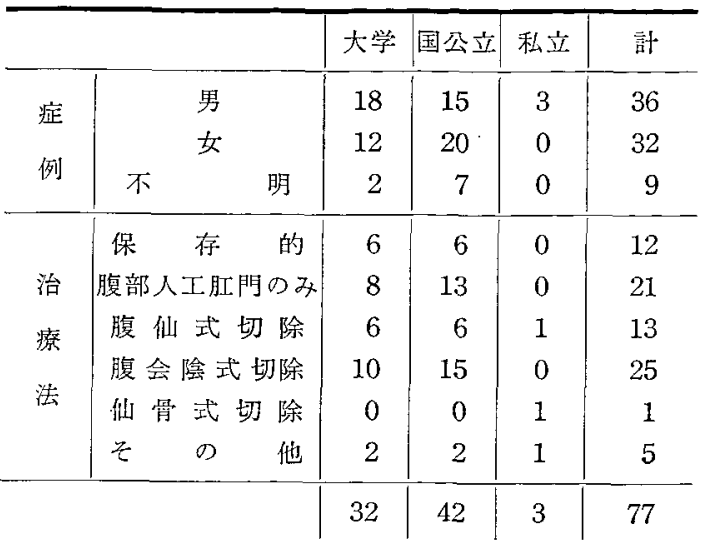

り，手術例では，腹会陰式切除が25例で最も多い，

42 年までにわれわれは 3 例の扁平上皮がんを経験し

た. 1 例はぢ核の手術をうけており，1例はぢ瘦から発 生したと考えられ，1例梳尖圭コンジローマが共存して いた，ロイコプラキー，ぢ核，裂肛，粘膜脱，淋巴肉芽 腫，放射腺も関係があるようであるが，ぢ渡が誘因とな る症例が中でも多いようである。

肛門がんが，肚門上皮，肛囲皮䖉，あるい噛状線以 下に限局していて，そけい淋巴節転移のないごく早期の ものは，直腸切断をしなくてもすむ場合も㐫る゙，浸潤 が直腸に及べば, 直腸がんに準じて腹会陰式根治術を行 わねばならず，更に肛門周囲皮膚は，脂肪織を大きく含 め切除を要する，そけいリンパ節転移のみられるもの は，予後が非常に悪くなる。

12) 鎖肞.

鎖肛は症例が多く表16のごとく106例で，やはり手術 例中約半数が腹部人工肛門をつくっていること湔と変

表 16 鎖肛（症例数）

\begin{tabular}{|c|c|c|c|c|}
\hline & 大 学 & 国公芒 & 私 立 & 計 \\
\hline 的 & 9 & 1 & 0 & 10 \\
\hline 単 純 切 開 & 24 & 5 & 2 & 30 \\
\hline 腹部人工肛門造設 & 30 & 15 & 2 & 46 \\
\hline そ の & 14 & 1 & 3 & 18 \\
\hline & 77 & 22 & 7 & 106 \\
\hline
\end{tabular}

わりない，低位鎖肛でも，将来の肛門㙨能を考えて，肛 門部の外科的処置を直ちに行わず，人工肛門をまず作成 すべきである，低位鎖肛でも直腸膀腅瘦，直腸尿道搟， 直腸会陰㜢, 直腸胵浢などの合併もあるので, 充分検查 をして根治手術を慎重に行うべきである，集計では質問 の趣旨が不明膫のため，治療方針についてはつかめなか

ったが新生児期の処置に関してであった。

以上 10 年前の肚門部疾患と比べて，とくにその代表的 なら゙核の治㙩に関して著しい変化がみられ，手術的には 結禁切除法がとりいれられ, 又大学, 国公立病院でむ注 射㙩法が行われてきたことは，大きな変り方と思う，又 反面, 注射療法, 手術療法後の肛門機能障害が 3 倍もふ えたことは，肚門疾患といえども，決して安易に考えて 行ってはならないことを充分に反省すべきである.

な㧍，手術体位，手術前後の処置についても大きく変 化がみられ，とかくなおざりにされていた肛門部疾患の 治療に関して，国公立病院，特に大学方注目してきたこ とは，10年前と大きな違いであり，本学会が年々盛会に なってゆくのが何よりの証拠といえよう.

な扛門がんについては，従来の直腸がんがこの中に 一部含まれているようにも考えられ，これは，肛門がん の定義が一定していないことに起因するもので，これは 直腸, 肛門部の解剖, 名称を含的て, 早く本学会で統一 見解を出すべきものと思う.

最後に貴重な資料をご回答下さった各大学，病院医局 の方タに哚く感謝の意を表する。

\begin{tabular}{|c|c|c|}
\hline & 大 & 学 \\
\hline 岩手医大 & 瀬田外科 & 東北大 槙外科 \\
\hline 千葉大 & 綿貫外科 & 日本大 石山外科 \\
\hline 日本医大 & 斉藤外科 & 東 大 石川外科 \\
\hline 昭 和大 & 石井外科 & 信州大 林外科 \\
\hline 金沢大 & 卜部外科 & 名古屋大 橋本外科 \\
\hline 岐阜大 & 鬼束外科 & 京 大 木村外科 \\
\hline 阪大 & 陣内外科 & 大阪医大 盛 外 科 \\
\hline 大阪市大 & 白羽外科 & 神戸大 麻田外科 \\
\hline 德島 大 & 田北外科 & 岡山 大 砂田外科 \\
\hline 鳥 取大 & 綾部外科 & 久留米大 脇坂外科 \\
\hline
\end{tabular}

\section{国公立病院}

国立東京第二病院 国立霞尔浦病院 都立駒込病院 立川病院 国保福生病院 川槣市立川崎病院 中南国保病院 済生会兵庫病院 足利赤十字病院 佐野厚生病院 浜松赤十字病院
国立久里浜病院 中央铁道病院 国家公務員共済 済生会中央病院 済生会神奈川病院 川崎市立井田病院 日本鋼管病院 公立岩瀬病院 大田原赤十字病院 下谷病院 田浦共泌病院 


\section{社会保除病院}

北辰病院北海道中央病院 宮城第一病院福舅二本松病院 雀宮病院埼玉中央病院 大智病院都南病院 池袋中央病院横浜中央病院 川崎中央病院相模野病院 鮴沢病院伏木病院 鳴和病院勝山病院 桜ケ丘病院三島病院 浜松病院滋賀病院 勡馬口病院神戸中央病院 大和郡山病院德山中央病院
下関厚生病院留米第一病院 浦之崎病院人吉病院 八代病院南海病院 宮崎江南病院松阪市民病院 広島市民病院小合記念病院 紀南病院中央病院

\section{私立病院}

湘南中央病院佼成病院 三翰病院松島病院 荻䆶病院前田病院

管原病院宮田医院

(順不同) 


\title{
Scientific Articles
}

\section{Surgical Approach to Polyp That has developed in the Rectum and Colon}

\author{
K. Katayama, M.D., K. Yanagita, M.D. and F. Miyashita, M.D. \\ The 1st. Dept. of Surgery, Toho Univ.
}

28 patients of polyp of the large intestine were admitted to our clinic for hospitalized treatment in the period from January, 1963, to July, 1969, and they comprised 25 cases of adenomatous polyp and 3 cases of villous polyp. Of these 28 cases, $6(21.4 \%)$ were found to be of malignant nature. The patients comprised a larger number of males, counting 22 $(76.7 \%)$, and 14 cases $(50 \%)$ were 40 years of age or older than that. They further could be classified to 20 patients of polyp of the rectum, and 8 patients of polyp of the sigmoid colon. The finding that the incidence of polyp in this region was overwhelmingly high conformed with the findings by other workers, and may be considered to mean that it is difficult to find polyp in the regions upper than the sigmoid colon.

Such operational methods have been employed at our clinic, viz., simple polypectomy was performed in 13 of 22 cases of benign polyp, ligature excision in 7 cases of polyp around the dentate line, and partial sigmoidectomy in another who had a polyp of a size of $2.5 \times$ $3.0 \mathrm{~cm}$ for a risk of it turning malignant. Hemicolectomy, total colectory, pull-through operation and Miles' operation were carried out in malignant cases.

\section{A Pedigree of Familial Poliposis with Cancer, especially Study on it's Pathohistology}

\author{
S. Koganezawa, M. D. \\ Dep. Surg., Kosei Gen. Hosp. Tokyo \\ Y. Tokoro, M. D. \\ Dept. Pathol., Univ. Tokyo
}

In order to recognize the presence of precancerous lesions, a pathohistological study of all polyps was carried out on the numerous polyps of the colon and rectum of a patient (female, 25 years) on whom a total colectomy and with permanent ileostomy was performed.

The results were as follows :

1. The total number of polyps was 920 and they were pathohistologically all sessile adenomatous polyps except for one which was pedunclated.

2. These polyps were classified into five groups according to the degree of malignancy starting from benign, atypia I, atypia II, atypia III, and cancer. The result was benign 260 , atypia I 234, atypia II 256, atypia III 137 and cancer 33 polyps.

3. The highest incidence of local for malignant polyps was found in the order of 
descending colon, sigmoid colon, rectosigmoid, transverse colon, rectum and ascending colon.

4. Most of the malignant polyps were large in size, though 75 (8.1\%) were small (below $2 \mathrm{~mm}$. in diameter).

The patient's sister was found also to have colonal polyposis with sigmoid cancer.

42 polyps with sigmoid cancer were romoved. None of 42 polyps were cancerous, but 18 of them were of atypia II type.

The electron microscopic findings of a few polyps of the patient'sister showed slight atypia such as gathering of chromatin surrounding nucleus, irregulary shaped of nucleolus, and also the surface of the cell showed an nuclear striated boarder and a few microvilli. There were relatively few goblet cells in the polyp which coincides with the ordinary light microscopic findings.

\title{
22. Familial Colic Polyposis complicated by Rectal Cancer
}

\author{
Y. Kaneko, M.D., K. Nagaoka, M.D., C. Tsukamoto, M.D. and \\ T. Shiratori, M.D. \\ Maki Laboratory of Surgery, Tohoku Univ.
}

I encountered a family, with the occurrence of colic polyposis accompanied by rectal cancer in 3 members, viz. the eldest brother, eldest sister and second eldest sister out of 6 brothers and sisters.

It is a disease rarely encountered in Japan, and there have been only 3 cases reported, including the present case.

Extensive proctocolectomy was performed in Case No. 1 , male, 43 ; total proctocolectomy in case No. 2, 34, female, and proctosigmoidectomy in Case No. 3, 28, female.

Case No. 2 died of recurrence 3 years after the operation. The other two cases have been under observation on prognosis.

\section{Juvenile Colonic Cancer}

D. Jinnai, M.D. and M. Yasutomi, M.D.

The 2nd. Dept. of Surgery, Osaka Univ.

We have undertaken a study of juvenile colonic cancer encountered by us at the Second Department of Surgery, Osaka University, from 1953 to 1968, and at Jinnai Laboratory of Surgery, Okayama University, from 1943 to 1962.

Out of 426 cases of colonic cancer, juvenile cancer at the age of 29 or younger was found in 26 cases, viz. 5.6\%. All of the 26 cases were distributed between the age of 20 and the age of 29 , and comprised 17 males and 9 females, viz., a mele-to-female ratio of 2 to 1 . 
They had undergone surgical operation within one year of morbidity period. The main complaint was mucous, bloody stool or bloody stool in $73 \%$ of them. $37 \%$ of them complained of dyschezia.

The rate of radical operation is $80.6 \%$ on an average for all patients of colonic cancer, but was far lower, viz., $61.5 \%$ in the patients of the age of 29 or younger.

The survival rate, viz., the 5-year survival rate is $40.8 \%$ for all in patients of colonic cancer, but was as low as $23.8 \%$ in juvenile patients.

The 5-year survival rate after radical operation is $52.3 \%$ for all patients of colonic cancer, but was as low as $33,3 \%$ in juvenile cases.

It may thus be said that not only radical operation can be performed in a less number of juvenile patients, but the prognosis after radical operation is extremely poor in them.

\title{
24. Early Cases of Carcinoma of the Colon and the Rectum
}

\author{
S. Tsuchiya, M.D., H. Kagami, M.D., Y. Kiribuchi, M.D., \\ T. Yamamoto, M.D. and S. Kusama, M.D. \\ The 1st. Dept. of Surgery, Univ. Tokyo
}

There were one case of sigmoid and 4 cases of rectal carcinoma infiltrating the mucosa only or infiltrating the submucosa but not infiltrating the muscularis propria in our 135 cases of carcinoma of the large intestine. In addition there were 9 cases of carcinoma infiltrating the muscularis propria but only infiltrating the superficial layer of the muscular coat. These 14 cases of the two groups were defined as the comparatively early cases and they were classified into groups according to the UICC classification. Special attention was laid on the clinicopathological features of the 14 "early" cases. All of the 5 carcinoma infiltrating the mucosa only situated below the sigmoid and were small polypoid lesions. There were involvement of the primary regional lymphgland in 2 cases of them. In all of the 9 cases of carcinoma infiltrating only the superficial layer of the muscularis propria no metastatic lesion was found but one of them died due to local recurring growth and one died due to liver metastasis.

\section{An Evaluation for Re-Exploration of Carcinoma of the Colon and Rectum}

Y. Uematsu, M.D.; M. Ohba, M.D., T. Akamatsu, M.D., N. Narahara, M.D., S. Kodaira, M. D., T. Mimura, M.D. and M. Uekusa, M.D.

Dept. of Surgery, Keio Univ. School of Medicine

Among 400 cases of carcinoma of the colon and rectum encountered at the Keio University Hospital for past twelve years, 120 cases were re-admitted for the evaluation of possible 
recurrency. On these cases, 43 subjects with the recurrent carcinoma and 14 subjects without recurrency both undergone reexploration are investigated in this study.

The recurrencies of carcinoma of the colon were found mostly as the intracolonic lesions and the peritoneal disseminations. The symptoms were mainly located in the abdomen such as abdominal pain, abdominal mass and intestinal obstruction. The resection of affected colons was performed as the re-operative procedure for the majority of these subjects. The survival rate after a year for the recurrent subjects with the re-exploration was $47.4 \%$.

The recurrencies of the rectal carcinoma were mainly regarded as the regional findings, the peritoneal disseminations and the distant metastasis, and their symptoms such as abdominal distress, abnormality of bowel movement were manifested $47 \%$ of the entire subjects, therefore, the palliative treatments such as the colostomy and the anastomosis of intestines were performed, and, their survival effect was remained fair. In the subjects with the re-exploration without recurrence, the stricture of the artificial colostomy, the intestinal obstruction and the perineal fistulas are frequently seen, and these were received the pertinent surgery in each subjects.

The follow up studies including the periodical check up of the symptoms appearing after the initial surgery is very important for the improvement of the forthcoming treatments. The improved survival could be expected if the active re-exploration and the re-removal of the recurrent sites are performed on the cases in which the recurrencies are suggestive.

\title{
26. Clinical Observation on 64 Cases of Cancer of the Colon
}

\author{
H. Chikuba, M.D., T. Endo, M.D., T. Todani, M.D. and K. Okajima, M.D. \\ The 1st. Dept. of Surgery, Okayama Univ. School of Medical
}

During the period from 1955 to 1968, 64 patients of colonic cancers who were never treated before admission were recieved our sergical survice. In these patients, 58 who were performed radical colectomies were selected and analyzed their clinical features; age, sex, location of the tumors, some factors having an influence upon the resectability of the cancers, prognosis and TNN classification of the cancers.

The most important article among the analysis, five years survival rate is $46 \%$. It is relatively better than those of the stomach $(50 \%)$ and the rectum $(41 \%)$, considering that most of the 58 cancers are generally in more advanced type than those of their cancers.

In order to elevate the survival rate, the surgical operation of colonic carcinoma in early stage is quite preferable. Therefore, the early operation which is only possible by using both a double contrast technique of the X-ray examination and the endoscopy is emphasized. 


\title{
27. The Statistical Study of Cancer of Large Intestine
}

T. Murakami, M.D., I. Tatekawa, M.D. and E. Kobayashi, M.D. Dept. of Surgery Juntendo Univ. School of Med.

The incidence of cancer of alimentary tract during past 5 years in our department shows $79.6 \%$ of gastric cancer and $12 \%$ of large intestine.

220 cases of cancer of large intestine treated from 1956 to 1968 were studied statistically. $70 \%$ out of 120 patients with cancer of colon is between 50 to 60 years old. Cancer of rectum is seen between 40 to 70 years of age. Ratio of male and female is two to one.

The initial symptom of rectal cancer is melena which is $55 \%$ and that of cancer of colon is abdominal pain which is $49 \%$.

On rectal cancer, tumor is palpable in 78 among 100 cases by digital examination.

When tumor is below peritoneal reflection, $98.6 \%$ is palpable.

On 71 cases among 100 cases, tumor is seen below peritoneal reflection.

The location of colon cancer is as follows; $40.8 \%$ is in sigmoid, $20 \%$ for ceacum and both transverse and descending colon give $10 \%$ respectively.

12 out of 49 cses with cancer of sigmoid were operated under the diagnosis of ileus. Operative procedure for rectal cancer is mainly abdominoperineal resection and anterior resection was done in 11 cases.

Resection is $68.8 \%$ and radical resection is $55.2 \%$. Lymphatic metastasis is $34.8 \%$. Five year survival is $50 \%$ and that of radical resection is $66.6 \%$. Resection of cancer of colon is $79.8 \%$ and radical resection is $54.6 \%$. Lymphatic metastasis is seen in $44.2 \%$. Five year survival is $41.5 \%$, and that of radical resection is $61.5 \%$.

\section{Statistical Observation on Cancer of the Colon and Rectum}

\author{
T. Kai, M.D., T. Hatayama, M.D., I. Adachi, M.D., A. Suzuki, M.D., \\ H. Senba, M.D., H. Asakura, M.D., R. Ito, M.D., A. Shiote, M.D., \\ T. Miyamoto, M.D. and Y. Senba, M.D. \\ Dept. of Surgery, Hiroshima City Hospital
}

From 1952 to 1969 , the cases operated at our hospital for carcinoma of the colon and rectum were 87 and 118 , respectively.

About those cases, statistical obsertations were made on sex, age, chief complaint, main symptom, suffering period and operative methode.

The five-year-survival-rate of those operated cases were calculated. 


\title{
29. Statistical Observations on Rectal Carcinoma
}

\author{
T. Ohgai, M.D., M. Takatsuki, M.D. and Y. Katayama, M.D. \\ The 1st. Dept. of Surgery, Toho Univ.
}

We have encountered 151 patients of rectal carcinoma in the past 9 years ever since 1960.

The male-to-female ratio was 1.3 to 1 . and classification of them by age indicated that the largest number of them were of ages of 50decades, and 10 of them, viz., $6.6 \%$, were below 30 years of age.

Bloody stool was found as the first symptom in $68 \%$ of them.

No particular correlations were found to exist between the period of morbidity and resectability.

To classify the patients by the site of carcinoma, it was found in the ampulla of the rectum in the largest number of them, viz., $63.6 \%$, and this finding conformed with the findings by other workers.

Radical operations were performed in $115(76.2 \%)$ of the 151 patients, conservative operations in $34(22.5 \%)$, and two $(1.3 \%)$ were found inoperable.

Visual findings of the resected specimens indicated that cancer of Borrmann's type III was present in the majority of them, viz., $86.7 \%$, and tumor of $\mathrm{T}_{3}$ size in $79(52.3 \%)$. Metastasis to lymphatic glands was found in 85 patients $(56.3 \%)$, and that to the liver, in 4 .

Pathohistological examination revealed that the tumor was adenocarcinoma in 138 patients $(91.3 \%)$, squamous cell carcinoma in $4(2.6 \%)$, and malignant melanoma in $4(2.6 \%)$. To group the patients by Dukes' classification, $27.2 \%$ of them belonged to group $\mathrm{A}, 23.8 \%$ to group $B$, and $49 \%$ to group C, viz., about half of them belonged to group $C$. This indicates that many of them were in an advanced stage of cancer, and this could be considered to be the factor on which the survival rate largely depended.

\section{Frequency of Cancer of the Rectum and Anus}

\author{
H. Narumi, M.D. and N. Mitaki, M.D. \\ Tohoku Proctologic Clinic \\ K. Obara, M.D. \\ Hanaoka Mining Co. Hospital \\ Y. Sugiyama, M.D. and S. Nishida, M.D. \\ The 2nd. Dept. of Surgery, Hirosaki Univ. School of Medicine
}

During the period between 1966 and 1969, 6063 patients admitted to Tohoku proctologic clinic. Of these patients, 24 cases of anorectal caneer $(0.4 \%)$ were found out.

They had some complaints of the anorectal region. 
In 1961, mass examination of the rectum and anus was performed in Aomori prefecture.

Of the 1003 cases of which $916(91.4 \%)$ had some complanits, 2 cases $(0.2 \%)$ were diagnosed rectal cancer.

During recent 2 years, 1008 labourers of Hanaoka Mining Co. were periodically examined the rectum and anus in spite of no complaint. It resulted in no cancer. Especially female examination rate was lower than male. Ninety percent of cancer of the rectum and anus fall in the rectal ampulla region. Performing positive examination, early diagnosis must be established.

\title{
31. Electromyographic Study of the Anal Sphincter in Rabbit
}

T. Sugisawa, M.D., H. Narumi, M.D., K. Suzuki, M.D., M. Abo, M.D., Y. Sugiyama, M.D., J. Kakizaki, MD., M. Takeuchi, M.D.,

N. Kudo, M.D., K. Kimura, M.D., K. Ono, M.D. and K. Ohuchi, M.D.

Dept. of Surgery, Hirosaki Univ. Faculty of Medicine

(Director: Prof. K. Ohuchi)

An electromyographic study of the anal sphincter muscle was performed using 40 rabbits.

A bipolar needle electrode was inserted in the anorectal region and electrical activity from the anal sphincter was recorded on the oscillographic paper.

The results obtained were as follows:

1. Anal spike potentials were not observed in $50 \%$ of experimental animals studied under the rest condition.

2. In a condition which the rectum within $3 \mathrm{~cm}$ from anal ring was distended an increase in electrical activity of anal sphincter was observed.

3. When bethanechol chloride was given by the intramuscular injection anal spike potentials were markedly increased and vigourous bowel movements were observed. On the other hand, the anal action potentials were not influenced by the administration of HyscinN-bytylbromidium.

4. The marked decrease in the anal electrical activity was observed under the condition of incontinence after sphincterotomy, but these phenomena were improved day by day.

\section{A Microscopic Histochemical Study of the Anal Canal}

\author{
(Second Report) H. Higaki, M.D. \\ The 1st. Dept. of Surgery, Gifu Univ. School of Medicine. \\ (Director Prof: K. Inada, M.D.)
}

A histochemical study of the human anal canal was made on 14 fetus ranging in the age from 4 to 6 months, 4 newborn infants, 1 five-year old child and 14 adults. The anal 
gland usually extending through the internal sphincter muscle has a simplified branched tubular structure and was composed of 2 to 4 layers of the columnar or cuboidal epithelium. The anal glands were functionally meocrine in fetus, and holocrine in newbor infants and adults. Activity of secretion was observed even in a specimen obtained from 78 years old man. The mechanism of the secretion was as follows:

The nucleus of the columnar cell in the superficial layer of the anal gland shifted to its basis and was deeply stained by the method of nucleus staining. The columnar cell observed here was fallen off from the wall to the lumen of the gland. The nucleus became smaller and smaller. The cytoplasm observed was stained by mucin staining. Then, the cytoplasm was dissolved and became mucoid. In the anal gland there were two kinds of secretes, one of which gave positive with mucin staining and the other one with nucleus staining. Both secretes were stained red-purple in colour on PAS staining, but gave negative on protein staining by ninhydrin and on mucin staining by toluidine blue. Some specimens taken from two adults were examined by Sudan III staining. In one case a portion of secrete and epitheliar cells of the gland gave positive, but failed to stain in other case. On the basis of these results mentioned above it can be concluded that secretes from the anal gland consist of muco-saccharide and contain fat, and that the anal gland and duct have ability to store the secretes transiently.

\title{
33. The Significances of Clinical and Laboratory Examinations for Anal Diseases
}

\author{
Y. Matsushima, M.D., N. Suzuki, M.D. and A. Kinugasa, M.D. \\ Matsushima Hospital
}

The most of patients, suffered anal diseases are treated very easily by ano-proctologist for a reason of minor surgery. However, these patients are very sensible to surgical attacks, and thinks coursed by postoperative complications. Moreover, some of these patients had frequently important pathological changes, for example cardiovascular, diabetic, hematologic diseases and others, also may occur very serious complications. We must prevent such complications by measurement of pre- and postoperative physical and laboratory examinations. Authers frequently examined pre- and postoperative patients, and thinks that takes very good results for prevention of the postoperative complications. 


\title{
34. The Use of BM-S Supository and BM-O Ointment in the Cure of Certain Anal Diseases
}

\author{
S. Mise, M.D. and K. Masuda, M.D. \\ Oba Hospital, Kyoto \\ H. Masuda \\ Masuda Clinic, Kyoto
}

The local application of a new ointment and supository (contains $0.18 \mathrm{mg}$ Shikon extract) was performed for the cure of the thrombosed haemorrhoids, anal fissures and wounds after the fistulectomy.

In 17 cases out of 22 with blind pile and fissure in ano, a good result was obtained and also in 33 cases out of 39 with the wounds after fistulectomy, a considerable effective result was obtained.

\section{Clinical Application of Suppositories at our Laboratory}

T. Nitta, M.D., T. Takeuchi, M.D., S. Hattori, M.D., H. Honda, M.D. and H. Tkeuchi, M.D.

The 2nd. Dept. of Surg. Nagoya Municipal Univ.

Suppositories, viz., A : combined preparation, B : venous wall extract of animal, and $\mathrm{C}$ : anti-inflammatory antibacterial agent, were used at randem in 133 patients.

The effects of the suppositories were assessed in terms of such symptoms as bleeding, pain, pruritus, excretion of secretions, swelling, prolapse, foreign sensation, tenderness and diminishment of nodules.

The suppositories were found effective in the sequence of $\mathrm{C}, \mathrm{A}$ and $\mathrm{B}$. The ineffective cases were least in the group treated with $C$, and there was no difference in the number of ineffective cases between the group treated with $\mathrm{A}$ and that treated with $\mathrm{B}$. 


\title{
36. On a Standardization of Clinical Evaluation of Medicinal Treatment in Hemorrhoid
}

\author{
T. Sakabe, M.D. \\ 3rd. Dept. of Surgery, Nihon University, School of Medicine \\ Y. Sumikoshi, M.D. \\ Central Health Insurance General Hospital, Tokyo \\ Y. Matsushima, M.D. \\ Matsushima Hospital, Yokohama \\ K. Yanagita, M.D. \\ The 1st. Dept. of Surgery, Toho Univ. School of Medicine
}

It is very difficult to determine the clinical effect of medicinal treatment, such as oral administration of drug or suppository, of hemorrhoid.

We tried to evaluate the clinical effect by means of percentage of demerit mark after treatment by scoring each clinical symptoms and also history and sufferring period, using Fragivix, a new oral drug for hemorrhoid with double blind test.

\section{On the Comparison between the two Open Methods : Milligan-Morgan and Parks}

\author{
S. Masumori, M.D., T. Ozeki, M.D. and M. Nogaki, M.D. \\ Nogaki Clinic of Proctology Mizuho-ku, Nagoya
}

Among a variety of hemorrhoidal methods, the present drift is towards adopting what we call Milligan-Morgan Method as one of the open methods, which is to take the place of Whitehead Method and other closed ones.

In our Clinic we followed up for 8-12 months the following cases: 26 operated by Milligan Method, 15 partially and 27 completely, operated by Parks Method.

The Table of Operation Methods

\begin{tabular}{lcccccc} 
& Case & $\begin{array}{c}\text { Supplication } \\
\text { Abnormality }\end{array}$ & $\begin{array}{c}\text { Extraordinary } \\
\text { Findings }\end{array}$ & \multicolumn{3}{c}{$\begin{array}{c}\text { Defecation } \\
\text { Good/Unchanged/Bad }\end{array}$} \\
Milligan & 26 & 6 & $8(7)$ & 22 & 3 & 1 \\
Milligan +Parks & 15 & 1 & $5(2)$ & 13 & 2 & 0 \\
Parks & 27 & 1 & $7(12)$ & 22 & 5 & 0
\end{tabular}

The total of those not directly concerned with the operations, such as residual hemorrhoid, hypertrophied papilla, etc., is ( ).

The table tells as the results so far achieved that by applying Milligan Method, as many as 6 supplication abnormalities among 26 cases were observed. The extraordinary findings we got are 8,5 , and 7 in order of the table, with the exception of those not directly concerned 
with the operations, such as residual hemorrhoid, hypertrohpied papilla and the like. Each of those three cases had "fissura ani" and some others in number of 5,1 , and 5 . It follows from the above observations that two things should be strongly necessitated; the prevention against "fissura ani" by means of the anal digital dilation after an operation, and the aftercare of operated patients.

\title{
38. A Case of Obstinate Perianal Abscess. (Fistura-in-ano) Caused by Fishbone
}

\author{
K. Hosoya, M.D. and K. Tonooka, M.D. \\ Tonooka Proctologic Clinic
}

In perianal abscess, the anal fistula which is formed after pyocenosis is mostly attributable to anal crypt (cryptitis) or to chronic anal fissure, and in many cases its internal cavity exists in the said crypt. Lately we have had an experience of treating a case of obstinate perianal abscess and anal fistulization which is accompanying this abscess. We will report this case as follows :

The patient is a 44 -year-old male and is farmer by occupation. He was first examined on April 5, 1967. About one month before then, he had an extensive reddening and swelling and a moderate tenderness on the right perianus. He visited a neighboring doctor, and the case was diagnosed as perianal abscess. He received a large dose of antibiotics and antiphlogistics. As the result, his condition improved markedly. After about 3 weeks treatment, both swelling and pain almost disappeared, and so he stopped receiving the treatment. But about a week before he came to our clinic. Right perianal region began to redden and swell. So he came to our clinic on his acquaintances recommendation. When he first came to our clinic, we found a reddened and swelled area of the size of the palm with an ischian knot as its center. There was tenderness, but no marked fluctuation was noticed. The reddened area was still marked.

Immediately the 11 o'clock section of the right perianus was cut open, but there was little pyocenosis considering the large area of swelling. Then a week passed but the reddening and swelling seen on the 9 o'clock section below did not disappear or lessen. So a week later, the 9 o'clock section was cut open, but there was little pyocenosis this time again. On April 25 , as the pyocenosis decreased fistulotomy was performed. About three weeks after operation, his surgical wound was almost healed, and he was discharged from our clinic.

About 4 weeks after he was discharged, that is, on June 10, he came again for treatment of rededning and swelling of his right perianus. Again the 9 o'clock section was cut open, but this time again there was little pyocenosis. Three days later, as there was such a little pyocenosis, we attempted to enlarge the surgical wound. As we were making this attempt, we found a fishbone about $1.5 \mathrm{~cm}$ in length and $0.5 \mathrm{~cm}$ in width at the bottom of the wound. Now it was clear that the case was perianal abscess caused by fishbone. 
After the fishbone was removed surgically, the wound was healed comparatively early, and the patient was discharged in a little over two weeks. When he was going to be discharged, we told him to come back for examination as soon as he had an abnormal feeling on his perianus.

On July 20, the same patient visited us for the third time to have his swelling teated. We cut open the center of the indurative area of the right perianus, and from a considerably deep spot in the wound, we succeeded to extract another fishbone about $1.0 \mathrm{~cm}$ long, just like the one we had extracted before. This time again, the wound was healed very soon, and the patient recovered completely on September 6. Two years have passed since his recovery, but no abnormality is noticed on the right perianus. Thus he is considered to have recovered completely after the extraction of fishbones were those of a snakehead (mullet), a fresh-water fish.

When we review this case of perianal abscess, we find, as its characteristics, that, considering the magnitude of reddening and swelling, there is rather a small amount of pyocenosis, and that the tenderness and fluctuation of its discoidal induration are moderate. Therefore, when we notice these characteristics, we chould expect tentatively a case of perianal abscess caused by foreign bodies, and examine the internal cavity and the bottom of the surgical wound when we have cut open the perianus and are letting the pus issue.

\title{
39. One Case Report of Successful Bleomycin-therapy for Anal Cancer
}

\author{
A. Abe, M.D. and O. Inami, M.D. \\ Heiwadai-Hospital. Kobe
}

The effects of Bleomycin for squamous cell tumors are widely known.

A 44-year.old female with 7 months hystory of anal cancer was treated with a $220 \mathrm{mg}$ dose of Bleomycin for 20 days.

The histological healing of this case was proved by continuous-slice-methode.

The benefitable process, hystological changes and the complications were discussed.

\section{A case of Anal Cancer (Adenocarcinoma)}

K. Kodama, M.D, and A. Fujiwara, M.D.

Dept. of Surg. Osaka Medical College

Since one month 57 year-old male complained a small anal tumor at the time of defecation, but no pain and bleeding. 
The tumor, cherry in size, was located on the dentate line and some part in the internal sphincter muscle. Soy bean in size at the base of the tumor was cystic.

Histological view of the tumor resected revealed adenocarcinoma about half of which showed mucous degeneration. Cystic formation was resulted from mucous degeneration of the cancer.

\title{
41. Case Report of Anal Cancer
}

S. Ishiyama, M.D., T. Sakabe, M.D., K. Kato, M.D., W. Funabashi, M.D., Y. Akieda, M.D. and T. Miyamoto, M.D.

The 3rd Department of Surgery, Nihon University School of Medicine.

There were 2 cases which the diagnosis of cancer was made by pathological examination undergone an operation of benign anal disease.

Case 1. 26-years-old. Man

Clinical diagnosis; Anal polyp.

Operative finding revealed pedicled polyp, the size of small finger on $3 \mathrm{~cm}$ upper from the anal ring which was removed. Pathological examination of the removed specimen revealed an adenocarcinoma on the top of polyp surface.

Case 2. 62-years-old. Man

Clinical diagnosis; Incarcerated internal hemorrhoid.

Operative finding revealed head incarcerated hemorrhoid on left posterior and there was ulcer in the center.

Ligature and excision operation was made to the hemorrhoid, and pathological examination revealed a squamouscellcarcinoma. One month after, the patient had an operation of abdominoperineal complete excision of the rectum.

Pathological examination of the removed rectum revealed the cancer extended to the muscle layer of $5 \mathrm{~cm}$ upper point from anal ring.

The patient was given $\beta$-tron radiation therapy.

Case 1. passed 6 years and Case 2. passed 8 months, they are still healthy.

\section{Giant Sacrococcygeal Teratoma in a Newborn Infant - a successful case operated on at 7 hours after birth -}

\author{
T. Hori, M.D., S. Sawaguchi, M.D., \\ T. Nakajo, M.D. and S. Ota, M.D.
}

The 1st. Department of Surgeay, National Children's Hospital.

A case report was presented of a $6200 \mathrm{gm}$, newborn girl who had a benign sacrococcygeal teratoma that was noted at birth. 
The mass overlying the sacrococcygeal area measured $25 \times 17 \times 10 \mathrm{~cm}$ and was globular, partly soft and cystic. A radiogram showed calcific deposites.

At operation the mass was found to extend to sacrum and behind the rectum and related intimately to the rectum. A mass weighing $2850 \mathrm{gm}$ was totally extirpated. The coccyx was also removed.

This tumor appears the largest one among successfully operated sacrococcygeal teratomas in newborn infants.

The patient was discharged on the 24th postoperative day, and she is living and well 5 months thereafter.

Sacrococcygeal teratoma shows a greater incidence of malignancy in a few months of life. Therfore, early surgical therapy should be indicated.

\title{
43. My Therapeutic Policy for Anal Disturbances
}

\author{
K. Toyonaga
}

Fukushima Prefecture.

I have been employing non-surgical therapy principally, corrosive injection therapy.

It is less in suppuration, pain and bleeding, and no hospitalization is necessary.

(Details on the injection therapy is not mentioned by orator.)

\section{Present Aspect of the Treatment of Anal Diseases}

Y. Sumikoshi, M.D. and M. Takano, M.D.

Central Health Insurance General Hospital, Tokyo

Statistical observations of anal deseases on the basis of the data obtained from 86 hospitals in 1967 are presented here with comparison to a similar report issued 10 years ago.

The ratio of general surgery patients to anal patients is 8 to 1 , with $66.5 \%$ of hemorrhoids, $13.5 \%$ of anorectal fistulae and $11.3 \%$ of anal fissures. Injection therapy for hemorrhoids is now adopted at 5 of medical college hospitals and 3 of national and public hospitals where such a treatment was never appreciated. Ligation \& Excision procedure is now used at 49 hospitals (57\%), whereas 'Whitehead' is carried out at $45(52 \%)$.

Nineteen hospitals have adopted Jackknife prone position by anal operation which was not likely used before. Pre- and postoperative managements have been simplified due to the adoption of an open drainage operative method.

As for anal cancer, its definition is not yet clear so that one does not know whether anal cancer means squamous cell carcinoma or carcinoma occurring at the anal region. It is necessary to determine the definition of anal cancer. 
One hundred and six cases of malformations of the anus and the rectum were treated and in half of them colostomy was performed.

Finally, the treatment for anal diseases has been gradually improved in Japan as shown by the fact that Ligation \& Excision method for the treatment of hemorrhoids has been adopted at more than half of the surveyed hospitals.

\title{
Symposium
}

\section{Long Term Result on the Whitehead's Operation}

\author{
M. Matsuishi, M:D. \\ Department of Surgery, Showa University, School of Medicine.
}

The statistical studies on the 217 cases who had operated for hemorrhoidal diseases in our department from 1964 to 1968 . We made inquiries about the postoperative dissatisfaction about between the group who had been treated by the Whitehead's method and the group by the Braatz's method. Satisfaction is $74.4 \%$ of the former and $43.3 \%$ of the latter. Then the recurrence of the hemorrhoids, the group of the Braatz's method is more than that of the Whitehead's method. And so on the anal stricture after the oporation, the group of the Braatz's method is more than that of the Whitehead's method. On the other hand, disagreeable complications these are to say prolapse of mucous membrane and anal insufficiency, is much more observed in the group of Whitehead's method.

Next, the investigation on the reoperation after the surgical treatment for hemorrhoidal diseases was performed. As the latter reoperation we treated with the Dieffenbach's method about the stricture of the anus after the operation of the Whitehead's method.

As the result of this observations, the Whitehead's method is better method than the Braatz's method so far as the good operater performed the operation.

\section{Long-Term Observations of Whitehead's Operation employed by Us}

\author{
H. Sakihara, M.D., H. Kobayashi, M.D., H. Taniguchi M.D., \\ and T. Shima, M.D. \\ Department of Surgery, Kure National Hospital.
}

We carried out operations on the anus in 368 patients in the 5-year period from January, 1964 to December, 1968. They comprised 200 cases of piles and prolapsus ani, and 168 cases of anal fistula, etc.

A modification of Whitehead's operation was adopted for operation on all cases of 